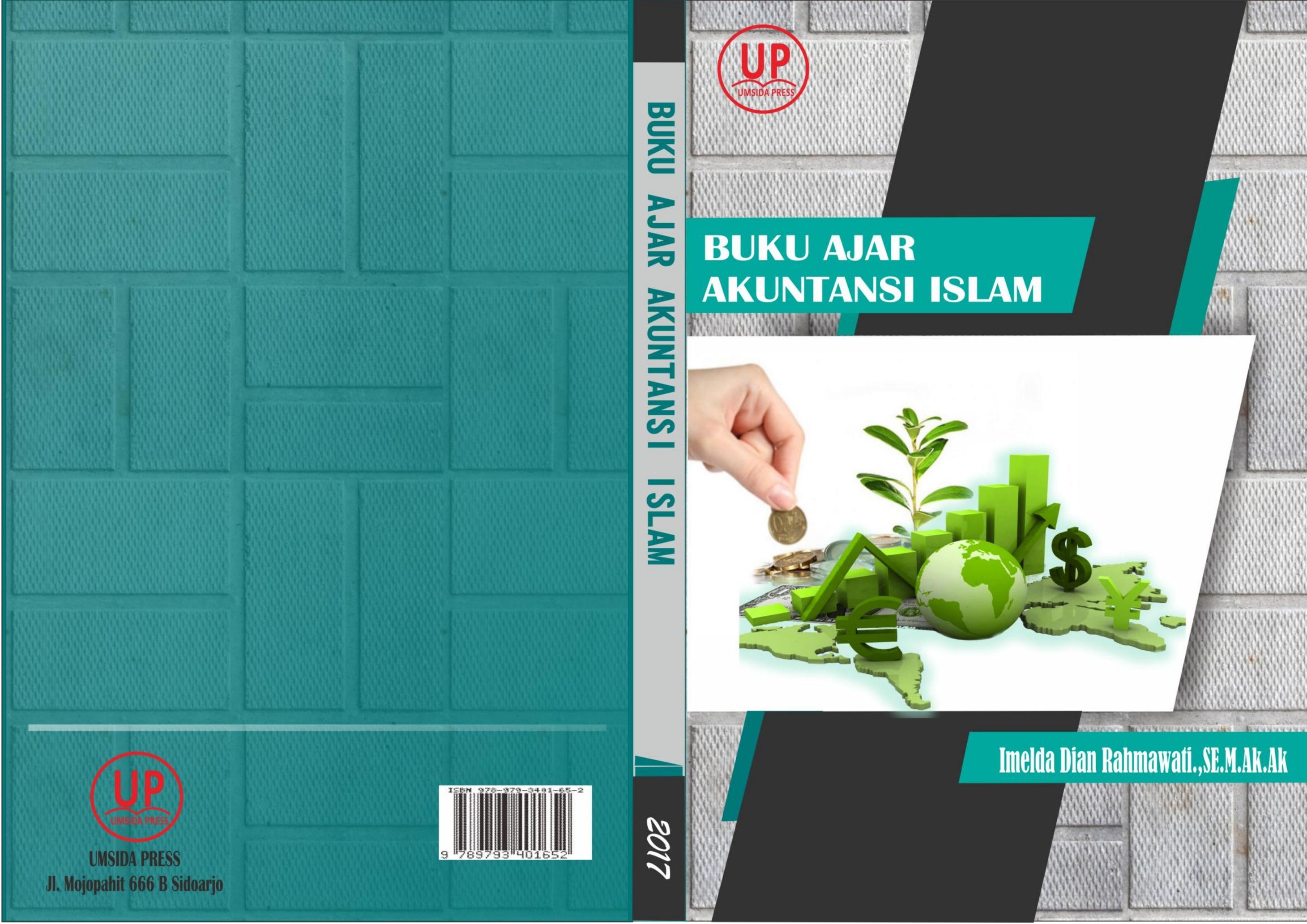




\section{BUKU AJAR \\ AKUNTANSI ISLAM}

\section{Penulis}

Imelda D. Rahmawati, SE, M.AK., Ak

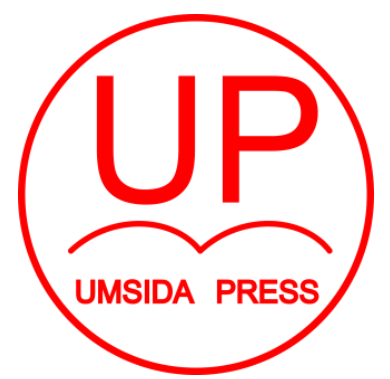

Diterbitkan oleh UMSIDA PRESS

Jl. Mojopahit 666 B Sidoarjo

ISBN: 9789793401652

Copyright $@ 2017$.

Authors

All rights reserved 


\section{BUKU AJAR}

\section{AKUNTANSI ISLAM}

\section{Penulis :}

Imelda D. Rahmawati, SE, M.AK., Ak

\section{ISBN :}

9789793401652

\section{Editor :}

Septi Budi Sartika, M.Pd

M. Tanzil Multazam , S.H., M.Kn.

\section{Copy Editor :}

Fika Megawati, S.Pd., M.Pd.

\section{Design Sampul dan Tata Letak :}

Mochamad Nashrullah, S.Pd

\section{Penerbit :}

UMSIDA Press

\section{Redaksi :}

Universitas Muhammadiyah Sidoarjo

Jl. Mojopahit No 666B

Sidoarjo, Jawa TImur

Cetakan pertama, Agustus 2017

(C) Hak cipta dilindungi undang-undang

Dilarang memperbanyak karya tulis ini dengan suatu apapun tanpa ijin tertulis dari penerbit. 


\section{KATA PENGANTAR}

Segala puji syukur kehadirat Allah swt atas terselesaikannya Buku Ajar cetakan yg ke 1 ini. Buku ini disusun dengan harapan lebih mempermudah pemahaman mahasiswa tentng akuntansi islam di dunia perbankan syariah. Karenanya disajikan dengan struktur bahasa yang mudah diterima oleh mahasiswa.

Seperti kita ketahui bersama, kiblat perkembangan dan praktek akuntansi islam di dunia perbankan syariah adalah Malaysia. Dan akhir-akhir ini perkembangan di Negara Eropa, yaitu Inggris sangat mengembirakan tentang akuntansi islam di perbankan. Hanya saja masyarakat disana tidak memahami tentang makna syariah, mereka hanya memahami bahwa perekonomian yang didalamnya ada perbankan syariah sangat menguntungkan dan mensejahterahkan masyarakatnya. Ini adalah bukti nyata praktek ekonomi islam, dan akuntansi menjadi bagian didalamnya

Sebuah harapan bagi kita semua, bahwa di Indonesia yang mayoritas masyarakatnya muslim mestinya perkembangan perbankan syariahnya bisa melebihi Negaranegara lain yang masyarakatnya non muslim. Buku ini 
diharapkan bisa memperkaya ilmu dan pemahaman mahasiswa tentang konsep akuntansi islam di Indonesia.

Disamping itu juga penulis berharap bisa menambah referensi tentang perkembangan akuntansi islam. Kami menyadari banyak kekurangan dan keterbatasan yang ada dalam buku ini. Semoga kedepan buku ajar ini bisa lebih sempurna dan memberikan manfaat kepada banyak pihak. Terimakasih.

Penulis 


\section{DAFTAR ISI}

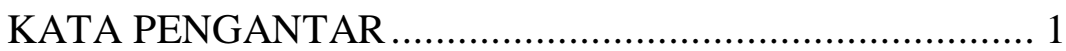

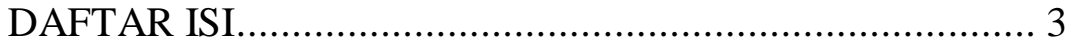

\section{BAGIAN 1 KONSEP AKUNTANSI SYARIAH ............... 1}

Tujuan Instruksional Umum:.............................................. 1

SUB POKOK BAHASAN ................................................ 1

1. Inti Dan Tujuan Studi Akuntansi Islam ............................. 1

2. Manfaat dan signifikansi Studi Akuntansi Islam ................ 2

3. Metode Akuntansi Islam................................................. 5

4. Dasar-Dasar Studi Akuntansi Islam .................................. 6

5. Metode dan Dasar yang Digunakan Dalam Studi

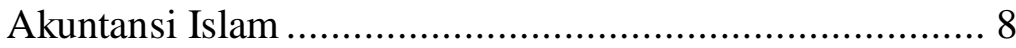

\section{BAGIAN 2 DASAR-DASAR GAGASAN AKUNTANSI}

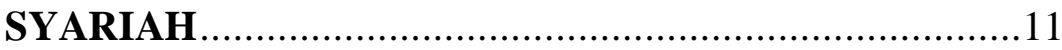

Tujuan Instruksional Umum............................................11

SUB POKOK BAHASAN …...........................................

1. Sejarah Gagasan Akuntansi Islam ....................................11

2. Pengertian Akuntansi dalam Islam ...................................15

3. Tujuan Akuntansi dalam Islam .......................................20

4. Jenis Akuntansi dalam Islam .........................................22

5. Sumber Dana Bank Syari'ah. ....................................27 


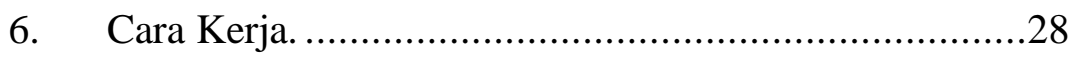

7. Inti Dasar Konsep Akuntansi Islam .............................36

BAGIAN 3 TEORI AKUNTANSI ISLAM.....................40

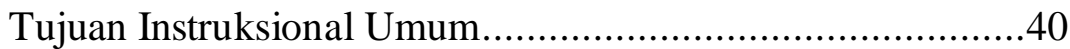

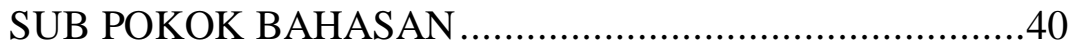

Beberapa Dimensi Akuntansi Menurut Alquran, Ilahiyah,

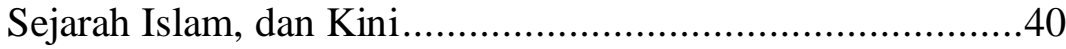

BAGIAN 4 KONSEP TRANSAKSI SYARIAH................75

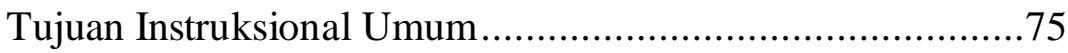

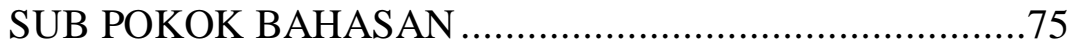

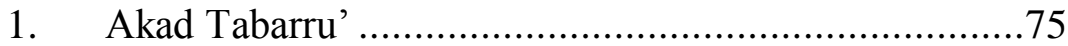

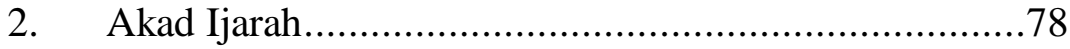

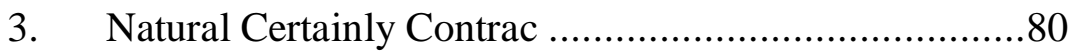

4. Natural Uncertainly Contrac........................................84

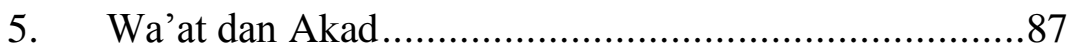

BAGIAN 5 KERANGKA DASAR PENYUSUNAN DAN PENYAJIAN LAPORAN KEUANGAN BANK SYARIAH ..............................................8

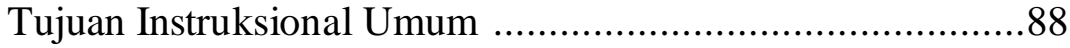

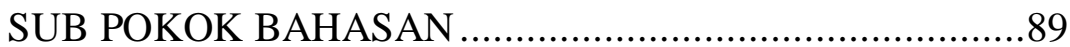

1. Pengantar Akuntansi Bank Syariah................................89

2. Tujuan Akuntansi Bank Syariah dan Tujuan Laporan Keuangan Bank Syariah ...........................................105 
3. Siklus Akuntansi Bank Syariah

4. Asumsi dasar, Pengakuan Akuntansi dan Konsep

Pengukuran Akuntansi

114

BAGIAN 6 AKUNTANSI PENGHIMPUNAN DANA....136

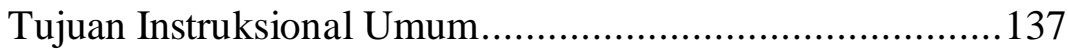

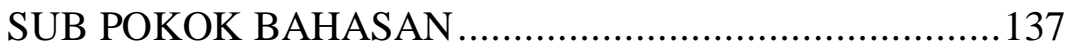

1. Gambaran Umum Perbankan Syaiah ...........................137

2. Penghimpunan dana Prinsip Wadiah............................137

BAGIAN 7 AKUNTANSI MURABAHAH ....................151

Tujuan Instruksional Umum...........................................151

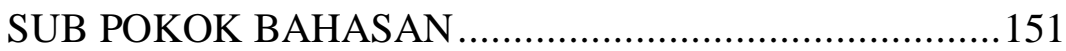

1. Pengertian dasar Akuntansi Murabahah .......................151

2. Ketentuan-ketentuan dalam Akuntansi Murabahah.......152

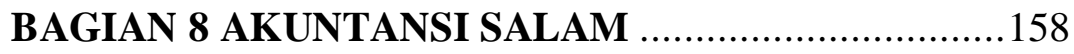

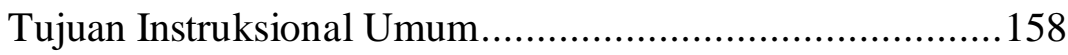

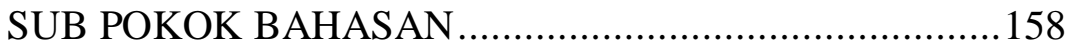

1. Pengertian dasar Akuntansi Salam .............................158

2. Ketentuan-ketentuan dalam Akuntansi Salam ............159 
3. Standar akuntansi Salam dalam PSAK No. 59 tentang Akuntansi Bank Syariah..........................................160

4. Perlakuan Akuntansi Salam.......................................164

BAGIAN 9 AKUNTANSI ISTISHNA …...........................168

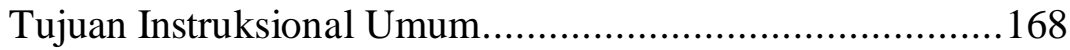

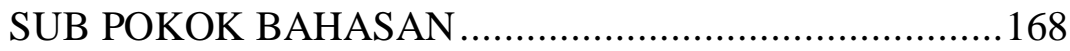

1. Pengertian dasar Akuntansi Istishna .............................168

2. Ketentuan-ketentuan dalam Akuntansi Istishna ............169

BAGIAN 10 AKUNTANSI IJARAH...............................

Tujuan Instruksional Umum............................................. 175

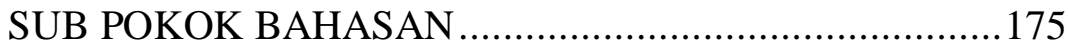

1. Pengertian dasar Akuntansi Ijarah .............................. 175

2. Ketentuan-ketentuan dan standar akuntansi yang digunakan dalam Akuntansi Ijarah.............................176

\section{BAGIAN 11 AKUNTANSI MUDHARABAH .................183}

Tujuan Instruksional Umum.............................................183

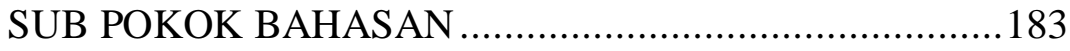

1. Pengertian dasar Akuntansi Mudharabah .....................183

2. Aturan-aturan yang berlaku dalam Akuntansi

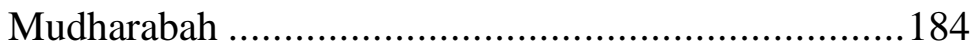




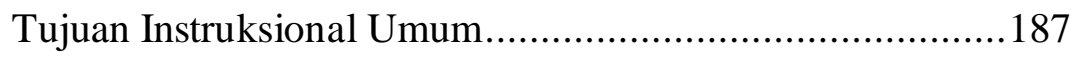

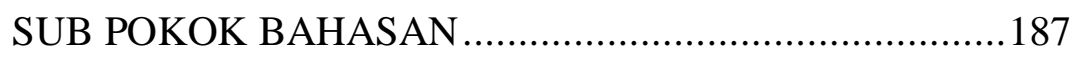

1. Pengertian dasar Akuntansi Musyarakah.......................187

2. Aturan-aturan yang berlaku dalam Akuntansi

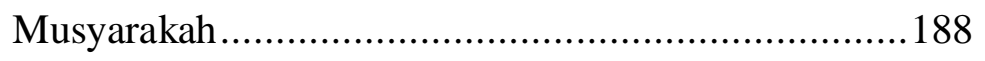

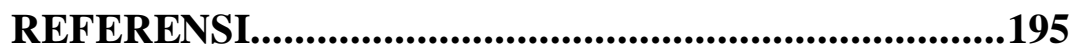




\section{IDENTITAS BUKU}

Judul buku

: Buku Ajar Akuntansi Islam

Penulis

: Imelda Dian Rahmawati.,SE.M.Ak.Ak

Penerbit

: Umsida Press

Cetakan

$: 1$

Tebal

: 100 Halaman 


\section{BIODATA PENULIS}

Imelda Dian Rahmawati.,SE.M.Ak.Ak. Lahir di Sidoarjo 13 Oktober 1978. Menyelesaikan pendidikan S1 di Fakultas Ekonomi Program Studi Akuntansi Univeristas Brawijaya Malang pada tahun 2002. Selanjutnya menyelesaikan pendidikan S2 Magister Ilmu Akuntansi pada tahun 2011 di Universitas Airlangga Surabaya. Dan sekarang sedang studi S3 Program Doktor Ilmu Akuntansi di Universitas Airlangga Surabaya. Saat ini penulis menjadi dosen tetap di Fakultas Ekonomi dan Bisnis Universitas Muhammadiyah Sidoarjo sejak tahun 2002 sampai sekarang. Tugas Akhir skripsi dan tesis yang diselesaikan concern di Akuntansi Islam yang menjelaskan tentang praktek akad syariah dan permodalan di Perbankan Syariah Nasional. Semoga Buku Ajar ini bisa memberikan manfaat bagi perkembangan ilmu akuntansi islam di Indonesia. 


\section{KATA PENGANTAR}

Segala puji syukur kehadirat Allah swt atas terselesaikannya Buku Ajar cetakan yg ke 1 ini. Buku ini disusun dengan harapan lebih mempermudah pemahaman mahasiswa tentng akuntansi islam di dunia perbankan syariah. Karenanya disajikan dengan struktur bahasa yang mudah diterima oleh mahasiswa.

Seperti kita ketahui bersama, kiblat perkembangan dan praktek akuntansi islam di dunia perbankan syariah adalah Malaysia. Dan akhir-akhir ini perkembangan di Negara Eropa, yaitu Inggris sangat mengembirakan tentang akuntansi islam di perbankan. Hanya saja masyarakat disana tidak memahami tentang makna syariah, mereka hanya memahami bahwa perekonomian yang didalamnya ada perbankan syariah sangat menguntungkan dan mensejahterahkan masyarakatnya. Ini adalah bukti nyata praktek ekonomi islam, dan akuntansi menjadi bagian didalamnya

Sebuah harapan bagi kita semua, bahwa di Indonesia yang mayoritas masyarakatnya muslim mestinya perkembangan perbankan syariahnya bisa melebihi Negaranegara lain yang masyarakatnya non muslim. Buku ini 
diharapkan bisa memperkaya ilmu dan pemahaman mahasiswa tentang konsep akuntansi islam di Indonesia.

Disamping itu juga penulis berharap bisa menambah referensi tentang perkembangan akuntansi islam. Kami menyadari banyak kekurangan dan keterbatasan yang ada dalam buku ini. Semoga kedepan buku ajar ini bisa lebih sempurna dan memberikan manfaat kepada banyak pihak. Terimakasih.

Penulis 


\section{DAFTAR ISI}




\section{BAGIAN 1 \\ KONSEP AKUNTANSI SYARIAH}

\section{A. Tujuan Instruksional Umum:}

1. Mengungkap inti konsep akuntansi syariah

2. Menjelaskan kemampuan dan peran akuntansi syariah dalam berbagai krisis.

3. Menjelaskan peranan akuntansi syariah dalam menyelesaikan persoalan-persoalan akuntansi yang meluas di masyarakat.

4. Tujuan dan manfaat dari studi akuntansi Islam

5. Metode dan dasar yang digunakan dalam studi akuntansi Islam

\section{B. SUB POKOK BAHASAN}

\section{Inti Dan Tujuan Studi Akuntansi Islam}

Inti dan Tujuan Studi Akuntansi Islam Studi disini berkaitan dengan kajian-kajian ideologi Islam, serta penetapan kaidah-kaidah dasar akuntansi menurut Islam. Juga berkaitan dengan studi-studi tentang implementasi ide-ide itu pada jaman modern, terutama di perusahaan atau lembaga-lembaga yang akan menerapkan hukum Islam dalam transaksinya, seperti bank-bank Islam, 
perusahaan-perusahaan asuransi Islam, serat lembagalembaga investasi dan permodalan islami. Dalam pembahasan ini akan fokus pada praktik akuntansi di perbankan syariah.

\section{Manfaat dan signifikansi Studi Akuntansi Islam}

Dalam hal ini manfaat akuntansi dalam perbankan syariah adalah:

1. Menyediakan informasi ekonomi mengenai keuangan yang bermanfaat bagi pihak-pihak yang membutuhkan.

2. Pertangungjawaban manajemen kepada pemilik perbankan atau investor.

3. Untuk mengetahui tren perkembangan perbankan dari tahun ke tahun

Dari pengalaman pada saat crisis moneter yang terjadi di Indonesia sekitar tahun 1996, perbankan syariah mampu survive. Hal ini yang menarik untuk semakin mempelajari akuntansi syariah. Yang dilakukan perbankan syariah adalah Bertahan Hidup Mengadopsi strategi survival menjadi suatu keharusan bagi manajemen 
bank syariah agar tetap bisa menjalankan fungsi intermediasi di waktu krisis. Strategi ini mencakup :

1. Strategi Konsolidasi. Strategi ini diaplikasikan melalui perlindungan dan penguatan posisi bersaing bank syariah di pasar. Ini tidak berarti manajemen hanya diam menyaksikan dinamika pasar dan invasi pesaing. Manajemen harus fokus pada core competence bank syariah terutama komitmen pada penerapan prinsip-prinsip syariah, kekuatan struktur modal, dan ketersediaan dana pihak ketiga. Kesadaran untuk memenuhi kompetensi akan membantu peningkatan sumber daya yang dimiliki sehingga memberikan posisi bersaing yang lebih baik dibandingkan pesaing.

2. Keunggulan Biaya. Pencapaian tingkat keuntungan bagi pemegang saham dan deposan yang lebih tinggi dari biasanya akan memudahkan bank syariah menerapkan strategi konsolidasi di atas. Cara terbaik adalah dengan memotong biaya operasional (service cost) yang dikeluarkan. Sesungguhnya struktur 
modal bank syariah tidak mengandung utang sehingga tidak ada pembayaran bunga tetap kepada deposan atau shahibul maal lainnya. Hal ini memberikan keunggulan bersaing bagi bank syariah dibanding bank konvensional karena tekanan terhadap manajemen terkait pengambilan risiko dan keputusan investasi akan sedikit mengendur. Oleh karena itu, biaya manajerial relatif lebih mudah ditangani daripada biaya bunga.

3. Merger dan Akuisisi. Berdasarkan pengalaman lembaga keuangan maupun nonkeuangan, strategi ini merupakan strategi yang paling umum direkomendasikan. Penggabungan usaha akan berpengaruh positif terhadap skala ekonomi, kemampuan bersaing dan bersinergi bank syariah. Namun ada sedikit catatan yang perlu diperhatikan, yaitu merger dua bank syariah yang lemah hanya akan menghasilkan sebuah bank syariah yang tidak cukup kuat. Perbedaan sifat (sumber dan penggunaan dana, struktur biaya) antara bank syariah dan bank konvensional juga harus 
benar-benar dipertimbangkan jika diterapkan pada dua jenis bank yang berlainan.

\section{Metode Akuntansi Islam}

a. Mengidentifikasi konsep akuntansi yang telah dikembangkan sebelumnya dengan prinsip islam tentang ketepatan dan keadilan. Sangat dimungkinkan seseorang akan menentang penerapan konsep-konsep itu, misalnya yag berkaitan dengan definisi karakteristik informasi akuntansi yang bermanfaat seperti relevansi dan realibilitas

b. Mengidentifekasi konsep yang digunakan dalam akuntansi keuangan konvensional, tetapi tidak sesuai dengan syariah islam. Konsep semacam itu ditolak atau dimodifikasi secukpnya dengan mematuhi syariah supaya lebih bermanfaat.

c. Mengembangkan konsep-konsep yang didefinisikan aspek-aspek tertentu dari akuntansi untuk bank islam yang tersendiri pada cara bertransaksi bisnis yang islami. 


\section{Dasar-Dasar Studi Akuntansi Islam}

Syariat Islam berkaitan erat dengan ibadah dan muamalah, dan tidak mungkin dipisahkan. Studi-studi dan riset dalam turats Islam (kandungan hukum Islam), seperti pokok-pokok keilmuan, pengumpulan konsep-konsep, kaidah-kaidah dasar, teori-teori serta aturan-aturan untuk menyelesaikan persoalan yang bersifat kekinian secara islami, erupakan suatu langkah yang sangat penting dan esensial, tanpa perlu membahas sama atau tidaknya dengan aturan-aturan konvensional. Sepanjang jaman, hukum Islam lebih memfokuskan pada kaidah-kaidah pokok yang sudah baku. Sesungguhnya maksud dan tujuan studi dan riset dalam ilmu-ilmu keislaman bukanlah untuk mendapatkan kehormatan duniawi, tetapi pada hakikatnya untuk beramal dan ibadah

Investasi merupakan dasar aktivitas ekonomi pada suatu masyarakat, tetapi tidak setiap individu mampu menginvestasikan tabungannya secara langsung. Karenanya bank islam memainkan peran penting dengan bertindak sebagai sarana untuk menarik tabungan para individu dan menginvestasikan tabungan-tabungan ini untuk kepentingan individu dan masyarakat. Islam secara jelas mendorong investasi dan perputaran dana. Ketika 
islam mewajibkan zakat iya mengharuskan bahwa harta harus diinvestasikan. Jika tidak, akan habis oleh zakat pada periode tertentu. Diriwayatkan bahwa nabi SAW bersabda "perdagangkan lah harta anak yatim itu jika tidak ingin habis termakan zakat." (HR Thabrani). Hadits ini menjelaskan bahwa sekali pun anak yatim itu masih kecil, tetapi kalau harta warisannya memenuhi nishab, maka wajib di penuhi zakatnya. Untuk tu, wali yatim wajib mengeluarkan atas nama si yatim (kaya) yang ada dalam perwaliannya.

Prinsip dalam hukum Muamalah adalah :

- Pada dasarnya segala bentuk muamalah adalah mubah, kecuali yang ditenttukan lain oleh Al qur'an dan sunnah Rasul.

- Muamalah dilakukan atas dasar sukarela dan tanpa mengandung unsur - unsur paksaan.

- Muamalah dilakukan atas dasar pertimbangan mendatangkan manfaat dan menghindari mudharat.

- Muamalah dilaksanakan dengan memelihara nilai keadilan dan unsur - unsur penganiyaan, pengambilan kesempatan dalam kesempitan (prinsip keadilan). 


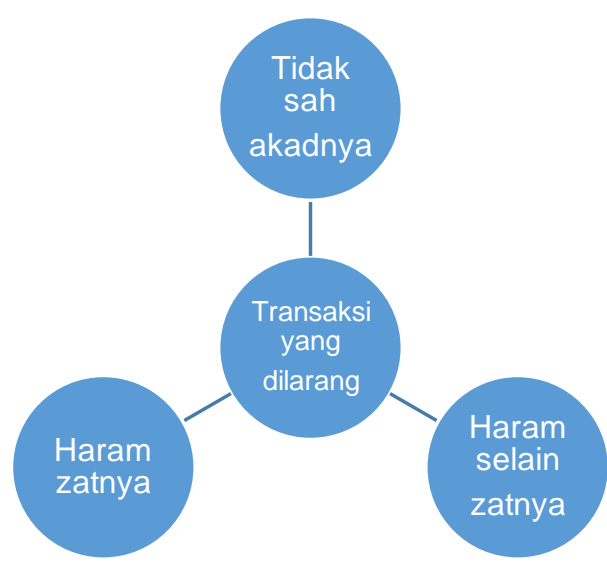

Gambar : Prinsip dalam Muamalah

\section{Metode dan Dasar yang Digunakan Dalam Studi}

\section{Akuntansi Islam}

1. Metode Eduksi, yaitu menyimpulkan dari sumbersumber hukum Islam yang muhktamat, yaitu :

a. Al-Qur'an, yaitu undang-undang Islam, yang terkandung di dalamnya hukum-hukum ibadah dan muamalah.

b. As-Sunnah, yaitu sebagai penjabar, penjelas, dan perinci hukum-hukum yang ada dalam Al-Qur'an

c. Ijtihad-ijtihad ahli fiqih dan ulama untuk meletakkan undang-undang dan peraturan- 
peraturan yang lebih rinci yang selalu disesuaikan dengan waktu dan tempat

d. Hasil-hasil praktek empirik sejak awal berdirinya Daulah Islamiah.

e. Kebiasaan yang sedang berlaku di masyarakat dengan syarat tidak bertentangan dengan syariat Islam.

2. Metode Analitis, yaitu membandingkan kaidahkaidah dan dasar-dasar akuntansi islami dengan teoriteori akuntansi positif, dengan membahas segi-segi persamaan dan perbedaannya.

3. Metode Aplikasi, yaitu membahas segi-segi implementasi terhadap dasar-dasar dan kaidah-kaidah akuntansi Islam di lingkungan perusahaan atau lembaga-lembaga yang ingin mengaplikasikan syariat Islam, serta pembahasan terhadap kendala-kendala yang kadangkala menghambat proses pertumbuhan dan perluasan implementasi tersebut. 


\section{EVALUASI}

Jawab dan Diskusikan soal-soal dibawah ini ;

1. Apa yang Anda ketahui tentang konsep Akuntansi Islam?Jelaskan.

2. Apa tujuan dan manfaat dari studi akuntansi Islam?Jelaskan.

3. Metode dan pendekatan apa yang dilakukan dalam mengembangkan Akuntansi Islam? Jelaskan 


\section{BAGIAN 2}

\section{DASAR-DASAR GAGASAN AKUNTANSI SYARIAH}

\section{A. Tujuan Instruksional Umum}

1. Menjelaskan kaidah-kaidah dasar akuntansi dalam Islam

2. Menjelaskan karakter dan tujuan dari akuntansi Islam

3. Mennjelaskan bidang penerapan akuntansi Islam

4. Gagasan lahirnya akuntansi Islam

5. Pengertian Akuntansi syariah baik ditinjau dari segi bahasa dan Al-Quran

6. Tujuan penerapan akuntansi dalam Islam

7. Jenis akuntansi Islam

\section{B. SUB POKOK BAHASAN}

\section{Sejarah Gagasan Akuntansi Islam}

Setelah munculnya Islam di Semenanjung Arab di bawah pimpinan Rosululloh SAW, serta telah terbentuknya Daulah Islamiyan di Madinah, mulailah perhatian Rosululloh untuk membersihkan muamalah (keuangan) dari unsure riba, dan dari segala bentuk penipuan, pembodohan, perjudian, pemerasan, monopoli, dan segala usaha untuk mengambil harta orang lain secara batil. Bahkan, Rosululloh menitikberatkan pada pencatatan 
keuanagn.Rosululloh mendidik secara khusus beberapa orang sahabat untuk menangani profesi ini dan mereka diberikan sebutan khusus, yaitu hafazhatul amwal (pengawas keuangan).

Di dalam Al-Qur'an, Allah sudah menggariskan bahwa konsep akuntansinya dalah penekanan pada pertanggung jawaban atau accaountability. Hal ini dapat dilihat dalam surat Al-Baqarah : 282, yaitu sebagai berikut:

\section{Artinya:}

"Hai orang-orang yang beriman, apabila kamu bermu'amalah tidak secara tunai untuk waktu yang ditentukan, hendaklah kaтu menuliskannya.dan hendaklah seorang penulis di antara kamu menuliskannya dengan benar. dan janganlah penulis enggan menuliskannya sebagaimana Allah mengajarkannya, maka hendaklah ia menulis, dan hendaklah orang yang berhutang itu mengimlakkan (apa yang akan ditulis itu), dan hendaklah ia bertakwa kepada Allah Tuhannya, dan janganlah ia mengurangi sedikitpun daripada hutangnya.Jika yang berhutang itu orang yang lemah akalnya atau lemah (keadaannya) atau Dia sendiri tidak mampu mengimlakkan, Maka hendaklah walinya mengimlakkan dengan jujur. dan persaksikanlah dengan 
dua orang saksi dari orang-orang lelaki (di antaramu). . ." (QS. Al-Baqarah : 282).

Nurhayati dan Wasilah mencatat bahwa ketika ada kewajiban Zakat, Ushr,Jizyah dan Kharaj maka Rasul mendirikan Baitul Mal. Ini terjadi pada awal abad ke 7.Pada ketika itu seluruh penerimaan dikumpulkan dan disalurkan untuk kepentingan negara.Pengelolaan Baitul Mal masih sederhana, namun telah terdapat jabatan Qadi, Sekretaris dan pencatat administrasi pemerintahan. Jumlah mereka mencapai 42 orang yang terbagai kepada empat bagian, yaitu sekretaris pernyataan, sekretaris hubungan dan pencatatan tanah, sekretaris perjanjian dan sekretaris peperangan. Zaid mengutip dari Hawary, bahwa jumlah 42 orang itu memiliki tugas masing-masing menyangkut penggajian pegawai pemerintah dan pajakpajak.

Khalifah yang melakukan pencatatan:

a. Abu Bakar.

b. Umar bin Khattab

c. Utsman bin Affand.

d. Ali Bin Abi Thalib 


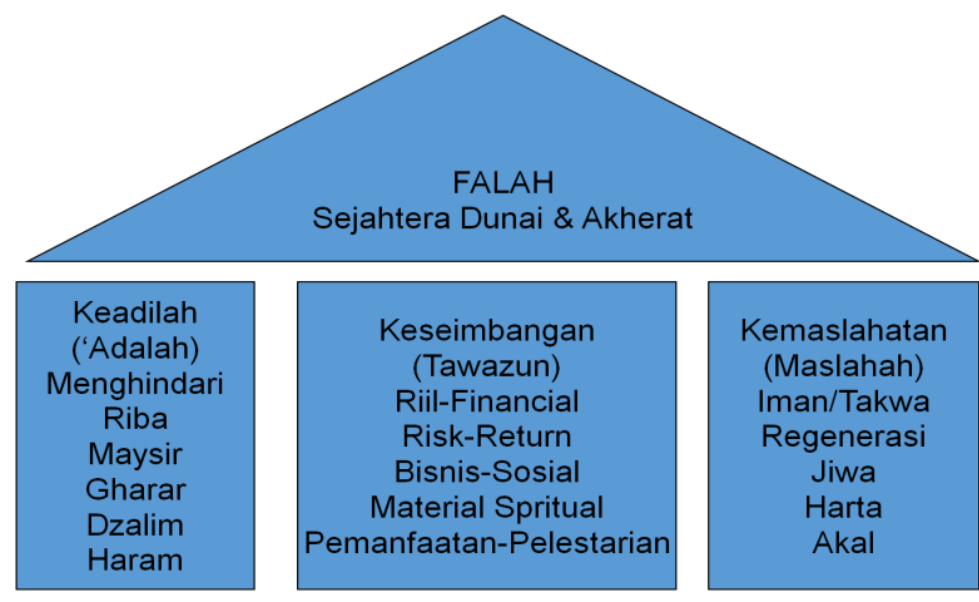

\section{UKHUWAH}

\section{SYARIAH}

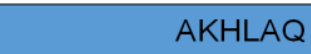

\section{AQIDAH}

Dari gambar diatas bisa dijelaskan bahwa tujuan manusia adalah untuk mencapai Falah atau kesejahteraan dunia dan akhirat, maka dapat dilakukan melalui keadilan, keseimbangan dan kemaslahatan. Jika 3 hal tersebut dapat dilakukan maka tahap selanjutnya manusia akan mencapai ukhuwah yang mempertimbangkan syariah dan akhlaq. Kemudian terbentuklah suatu aqidah yang menjadi dasar kehidupan manusia. 


\section{Pengertian Akuntansi dalam Islam}

Akuntansi syariah dapat dijelaskan melalui akar kata dimilikinya yakni akuntansi dan syariah.Akuntansi memiliki banyak definisi diantaranya pada tahun 1953, Committee on Accounting Terminology dari American Institute of Certified Public Accountants (AICPA) menyatakan bahwa: "Akuntansi adalah seni mencatat, mengklasifikasikan dan meringkas dalam bentuk yang berarti dan dalam unit uang tentang transaksi-transaksi dan kejadian-kejadian, yang paling tidak, memilki sifat keuangan dan menginterpretasikan hasil-hasilnya".

Akuntansi dalam bahasa arabnya adalah Al-Muhasabah berasal dari kata masdar hassaba-yuhasbu yang artinya menghitung atau mengukur. Secara istilah, al-Muhasabah memiliki berbagai asal kata yaitu ahsaba yang berarti "menjaga" atau "mencoba mendapatkan" juga berasal dari kata Ihtiasaba yang berarti "mengharapkan pahala di akhirat dengan diterimanaya kitab seseorang dari Tuhan", juga berarti "menjadikan perhatian" atau "mempertanggungjawabkannya"2. Jilka kata muhasabah dikaitkan dengan ihtisab dan citranya dikaitkan pencatatan, maka artinya adalah perbuatan seseorang secara terusmenerus sampai pada pengadilan akhirat dan melalui 
timbangan (mizan) sebagai alat pengukurnya, serta Tuhan sebagai akuntannya. Selain itu, jika kita cermati surat alBaqarah ayat 282, Allah SWT memerintahkan untuk melakukan penulisan secara benar atas segala transaksi yang pernah terjadi selama melakukan muamalah. Dari hasil penulisan tersebut, dapat digunakan sebagai informasi untuk menentukan apa yang akan diperbuatkan oleh seseorang. Sehubungan dengan ini, beberapa definisi akuntansi secara umum dapat disajikan, di antaranya:

Tujuan dari Akuntansi Syariah :

a. Tujuan utama dari akuntansi (Littleton) adalah untuk melaksanan perhitungan periodik antara biaya (usaha) dan hasil (prestasi).

b. APB (Accounting Priciple Board) "Akuntansi adalah suatu kegiatan jasa. Fungsinya adalah memberikan informasi Kuantitatif, umumnya dalam ukuran uang, mengenai suatu badan ekonomi yang dimaksudkan untuk digunakan dalam pengambilan keputusan ekonomi, yang digunakan dalam memilih diantara beberapa alternatif".

c. AICPA (Amercan Institute of Certified public Accountant) "Akuntansi adalah seni pencatatan, penggolongan dan pengikhtisaran dengan cara tertentu dan dalam ukuran moneter, transaksi dan 
kejadiankejadian yang umumnya bersifat keuangan dan termasuk menafsirkan hasilhasilnya".

d. Dalam buku SBAT ( $A$ Statement of Bank Accounting Theory) "Akuntansi adalah proses mengidentifikasikan mengukur, dan menyampaikan informasi ekonomi sebagai olahan informasi dalam hal pertimbangan dalam mengambil kesimpulan oleh para pemakainya".

Kesimpulanya, bahwa Akuntansi adalah suatu seni untuk:
a. Mencatat
b. Mengklasifikasika
c. Meringkas
d. Melaporkan, dan
e. Menganalisa

Sedangkan fungsi Akuntansi adalah:
a. Memberi informasi kuantitatif
b. Yang bersifat financial
c. Mengenai suatu usaha / business
d. Sebagai dasar pengambila keputusan (Wiroso, 2009).

\section{Prinsip Dasar Akuntansi Syariah3}

Berikut adalah ciri-ciri pelaporan keuangan dalam bingkai syariah: 
1. Dilaporkan secara benar (Q.S 10:5)

2. Cepat laporannya (Q.S 2:202; 3:19; 5:4; 13:41)

3. Dibuat oleh ahlinya (akuntan) (Q.S 13:21; 13:40; $23: 117 ; 88: 26)$

4. Terang, jelas, tegas dan informatif (Q.S 17:12; 14:41; 84:3)

5. Memuat informasi yang menyeluruh (Q.S 6:52; 39:10)

6. Informasi ditujukan kepada semua pihak yang terlibat secara horizontal maupun vertikal (Q.S 2:212; 3:27; $3: 37 ; 13: 18 ; 13: 40 ; 24: 38 ; 38: 39 ; 69: 62$ )

7. Terperinci dan teliti (Q.S 65:8)

8. Tidak teradi manipulasi (Q.S 69:20; 78:27)

9. Dilakukan secara kontinu (tidak lalai) (Q.S 21:1)

Kemudian pada tahun 1970, American Institute of CertifiedPublic Accountants (AICPA) membuat Statement of the Accounting Principle Board, No. 4 yang menyatakan bahwa: "Akuntansi adalah aktivitas jasa. Fungsinya adalah memberikan informasi kuantitatif, terutama informasi keuangan, tentang entitas bisnis yang dimaksudkan dapat berguna dalam membuat keputusan-keputusan ekonomi dalam membuat pilihan-pilihan yang rasional di antara beberapa 
alternatif tindakan". "Akuntansi sebagai sebuah aktivitas yang dirancang untuk mengidentifikasi, mengukur, dan mengkomunikasikan informasi tentang entitas ekonomi yang dimaksudkan dapat berguna dalam membuat keputusan-keputusan ekonomi."

Adapun kosa kata syariah dalam bahasa Arab memiliki arti jalanyang ditempuh atau garis yang seharusnya dilalui. Dari sisi, terminologi bermakna pokok-pokok aturan hukum yang digariskan oleh Allah SWT untuk dipatuhi dan dilalui oleh seorang muslim dalam menjalani segala aktivitas hidupnya (ibadah) di dunia. Sementara itu Zaid menyatakatan definisi akuntansi syariah sebagai berikut: "Muhasabah (akuntansi syariah), yaitu suatu aktivitas yang teratur berkaitan dengan pencatatan transaksi-transksi, tindakan-tindakan, keputusan-keputusan yang sesuai dengan syariat, dan jumlah-jumlahnya, di dalam catatan-catatan representatif; serta berkaitan dengan pengukuran hasil-hasil keuangan berimplikasi pada transaksitransaksi, tindakan-tindakan, dan keputusankeputusan tersebut untuk membantu pengambilan 
keputusan yang tepat". Adapun Nurhayati menyatakan bahwa akuntansi syariah dapat diartikan sebagai proses akuntansi atas transaksitransaksi yang sesuai dengan aturan yang telah ditetapkan Allah SWT.

\section{Tujuan Akuntansi dalam Islam}

Kajian Akuntansi Islam dimaksudkan untuk mengungkapkan inti konesp akuntansi Islam serta menjelaskan kemampuan dan perannya dalam berbagai krisis yang terus-menerus.Juga, untuk menyelesaikan persoalan-persoalan akuntansi yang meluas di masyarakat.Dengan kajian ini, terlihat bahwa syari'at Islam telah mencakup kaidah-kaidah akuntansi yang selama ini belum diketahui oleh pakar akuntansi modern.Kalupun ada yang mereka ketahui dan kebetulan itu cocok dengan Islam, itu hanya sedikit sekali. Hal ini bias dianggap sebagai salah satu mukjizat Islam. Tujuan yang diharapkan dari system Akuntansi Islam adalah melahirkan konsep-konsep dan praktek akuntansi yang sesuai denagn syari' at Islam, sehingga dapat memberikan kontribusi kepada kemajuan ekonomi dan praktek bisnis dan perdagangan yang lebih jujur, adil, bebas dari praktek 
kecurangan dan riba, kolusi, kezaliman, dan penipuan lainnya. Berkenaan dengan tujuan Akuntansi Islam, terdapat beberapa pendapat dari ahli-ahli akuntansi, antara lain adalah Muhammad Akram Khan (1992) mengemukakan bahwa Akuntansi Islam itu adalah menghitung laba rugi yang tepat, mendorong dan mengikuti syariat Islam, menilai efesiensi manajemen, melaporkan yang baik, dan keterikatan pada keadilan dan kebenaran.

Munculnya akuntansi islam ini di dorong oleh berbagai hal seperti:

1. Meningkatnya religiousity masyarakat.

2. Meningkatnya tuntutan kepada etika dan tanggung jawabsosial yang selama ini tampak diabaikan oleh akuntansi konvensional.

3. Semakin lambanya akuntansi konvensional mengantisipasi tuntutan masyarakat khususnya mengenai penekanan pada keadilan, kebenaran, dan kejujuran.

4. Kebangkitan umat islam khususnya kaum terpelajar yang merasakan kekurangan yang terdapat dalam kapitalisme barat. 
5. Perkembangan atau anatomi disiplin akuntansi itu sendiri.

6. Kebutuhan akan sistem akuntansi dalam lembaga bisnis syariah seperti bank, asuransi, pasar modal, trading, dll.

7. Kebutuhan yang semakin besar pada norma perhitunganzakat dengan menggunakan norma akuntansi ysng sudah mapan sebagai dasar perhitungan.

8. Kebutuhan akan pencatatan, pertanggungjawaban, dan pengawasan harta umat misalnya dalam Baitul Mal atau kekeyaan milik umat islam atau organisasinya

\section{Jenis Akuntansi dalam Islam}
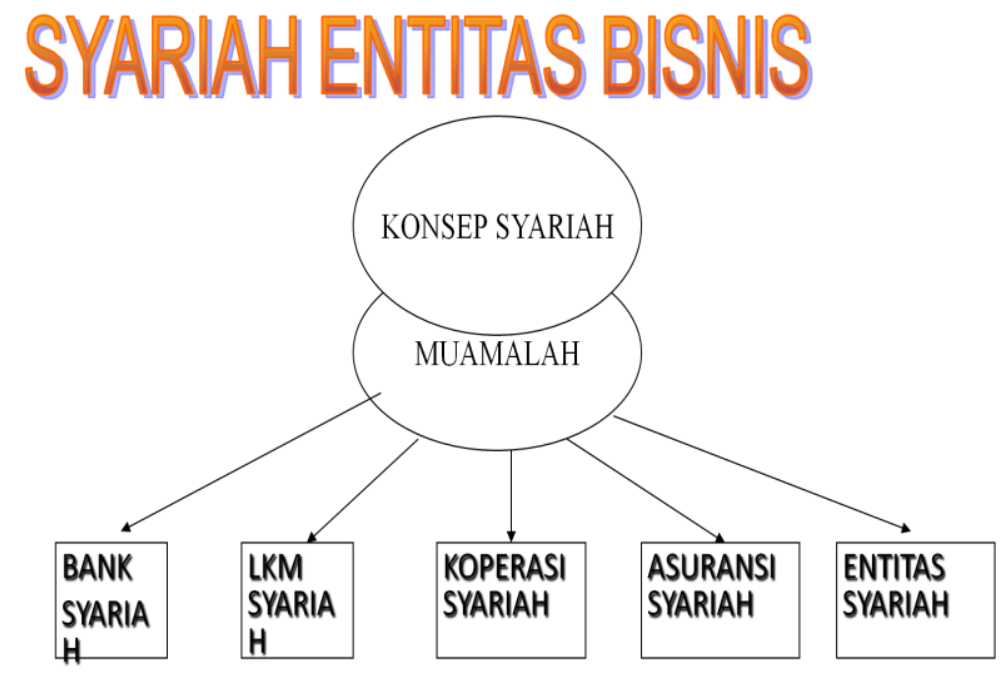


\section{A. Bank Syari'ah.}

Memang Bank Syari'ah ini tergolong baru bagi kalangan kita, Malaysia mengenal sejak 10 tahun yang lalu. Di Negara lain seperti Arab Saudi, Mesir, Jordan, Pakistan, Kuwait, Luxemburg, bahkan sudah dulu mempraktekkannya. Cara operasi Bank Syari'ah ini hakikatnya sama dengan Bank Konvensional, yang berbeda hanya dalam masalah bunga dan praktek lainnya dalam Islam tidak dibenarkan. Bank ini memang tidak memakai system bunga seperti Bank Konvensional.Namun bukan berarti bank ini tidak mengenakan beban kepada mereka yang menggunakan jasanya. Beban tetap ada namun konsep dan cara perhitungannya tidak seperti perhitungan bunga dalam bank konvensional.

Kedudukan Bank Syari'ah dalam system perbankan nasional mendapat pijakan yang kukuh setelahadanya deregulasi sector perbankan pada tahun 1983.dengan deregulasi sector perbankan tersebut, kepada lembaga keuangan bank diberikan keleluasan, termasuk dalam hal penentuan tingkat suku bunga (hingga nol persen) bahkan peniadaan bunga sekaligus. 
e. Produk Bank Syari'ah.

1. Pembiayaan dengan Marjin (Murabahah).

Murabahah adalah jual beli barang pada harga asal dengan tambahan keuntungan yang disepakati bersama. Dalam bai' almurabahah, penjual harus memberi tahu harga produk yang ia beli dan menentukan suatu tingkat keuntungan yang disepakati.

Dalam produk ini terjadi jual beli antara pembeli (nasabah) dan penjual (Bank).Bank membelikan barang yang telah ditentukan spesifikasinya oleh nasabah dan menjualnya kepada kepada nasabah dengan harga plus keuntungan.

2. Mudharabah.

Secara teknis, mudharabah adalah akad kerja sama usaha antara dua pihak di mana pihak pertama (shahibul maal) menyediakan seluruh modal (100\%), sedangkan pihak lainnya menjadi pengelola. Dan keuntungan usaha secara mudharabah dibagi menurut kesepakatan yang dituangkan dalam kontrak, sedangkan apabila rugi ditanggung 
oleh pemilik modal selama kerugian itu bukan kelalaian si pengelola.Seandainya kerugian itu diakibatkan karena kecurangan atau kelalaian si pengelola, si pengelola harus bertanggung jawab atas kerugian tersebut.

3. Musyarakah.

Musyarakah adalah akad kerja sama antara dua pihak atau lebih untuk usaha tertentu di mana masing-masing pihak memberikan kontribusi dana (atau amal/expertise) dengan kesepakatan bahwa keuntungan dan risiko akan ditanggung bersama sesuai dengan kesepakatan.

Dua pola terakhir sangat riskan dan perlu pengusaha yang benar-benar pengusaha yang jujur yang diyakini bank yang melaporkan laba ruginya dengan benar, dan menyegerakan membayar utangnya.Dan untuk sementara tampaknya Bank Syari'ah masih sukar menemukan pengusaha di kancah ekonomi sosial dengan kondisi sekarang ini. 
4. Bai' Bithaman Ajil (Trasaksi jual beli dengan harga tangguh).

Dalam konsep ini harga barang yang dijual kepada nasabah telah memperhitungkan pembayaran yang akan dilakukan kemudian baik secara angsuran maupun tangguh bayar. Harga yang ditetapkan adalah berdasarkan persetujuan bersama kedua belah pihak.Harga ini tidak dibenarkan diubah kendatipun keadaan ekonomi berubah.Jangka waktu pembayaran didasarkan pada kesepakatan bersama. Kalau dilihat dari dari Bank Konvensional, maka bai' Bithaman ajil ini dapat disetarakan dengan kredit investasi.Karena kredit yang diberikan adalah kredit investasi, maka bai' bithaman ajil bersifat long run financing. Prinsi ini dapat diterapkan pada semua jenis pembiayaan penuh yang merupakan talangan dana untuk pengadaan barang ditambah keuntungan yang disepakati dengan pembayaran cicilan. 
5. Al-Ijarah.

Al-ijarah adalah akad peminahan hak guna atas barang atau jasa, melalui pembayaran upah sewa, tanpa diikuti dengan pemindahan kepemilikan (ownership/milkiyyah) atas barang itu sendiri.

6. Al-Qardhul hasan (Pembiyaan Kebajikan). Produk ini merupakan produk Bank Syari'ah yang sangat khusus. Produk ini hanya bisa diberikan jika Bank Syari'ah sudah menerima zakat, infaq, shadaqah masyarakat yang menempatannya tidak mengharapkan bagi hasil dan ditempatkan di bank untuk dikelola dengan maksud meningkatkan kesejahteraan ummat khususnya yang mustahaq terhadap ZIS itu.

\section{Sumber Dana Bank Syari'ah.}

Sumber dana Bank ini adalah dari pemilik dan dari pihak ketiga atau masyarakat misalnya seperti Giro Wadi'ah (Rekening Koran), Deposito Mudharabah, Tabungan Mudharabah, dan tabungan untuk maksud khusus. Terhadap produk ini bank tidak memberikan 
bung, tetapai bagi hasil yang jumlahnya tidak akan diketahui pada awalnya, karena tergantung hasil yang diperoleh kemudian.

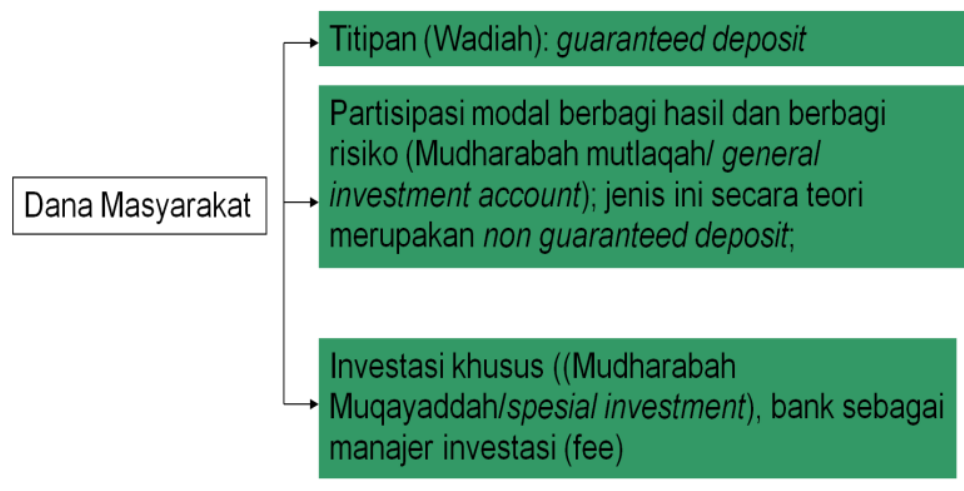

\section{DANA BS}

$$
\rightarrow \text { Modal (Core Capital) }
$$$$
\text { Kuasi Ekuitas (Mudharabah Account) }
$$

Titipan (Wadiah/Non renumerated

$$
\text { deposits) }
$$

\section{Cara Kerja.}

Cara kerja seperti pengikatan pembiayaan di Bank Syari'ah adalah sama dengan di bank lain. Ada akta perjanjian, ada saksi, dan yang penting ada jaminan yang dapat dipegang oleh bank sehingga dan yang diberikan diyakininya akan dikembalikan secara utuh beserta untungnya jika ada kepada bank.jaminan bisa berupa barang, tanah, rumah, kelayakan usaha, individu, perusahaan, kepercayaan dan lain-lain. Dan jaminan ini 
adalah upaya bank untuk menyelamatkan harta peminjam agar tidak ingkar bayar yang menurut syari'at sangat tidak disukai.

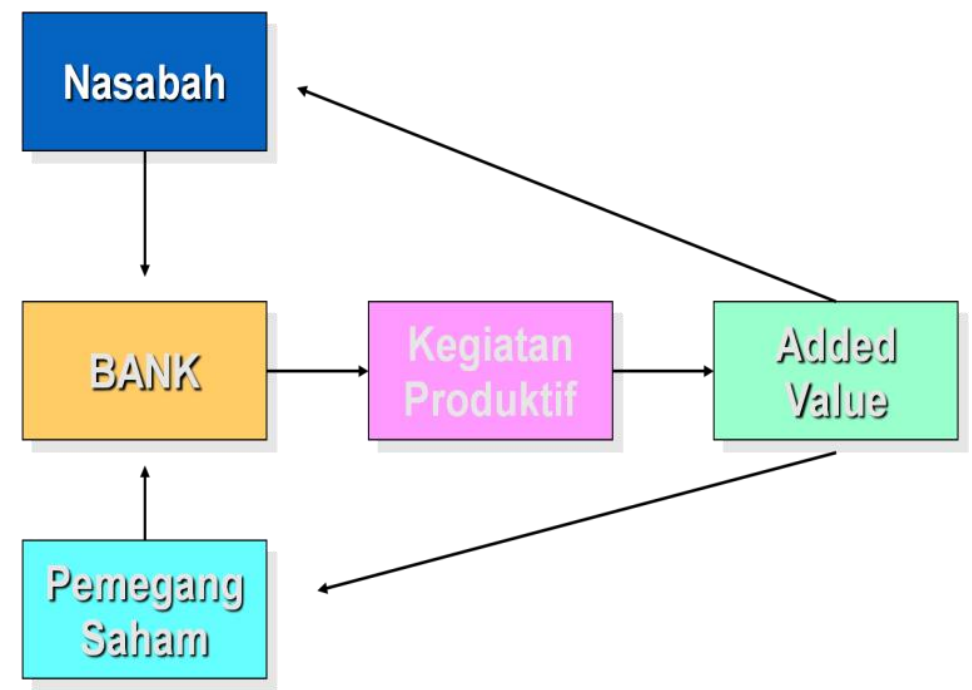

\section{B. Asuransi Takaful}

Menurut estimologi bahasa Arab istilah takaful berasal dari kata kafala.Dalam ilmu tashrif atau sharaf, takaful ini termasuk dalam barisan bina muta'aadi.Yaitu tafaa'ala, artinya saling menanggung.Dan ada juga yang mengartikan saling menjamin.Takaful seperti dikutip Juhaya S. Praja (1994:1), dalam pengertian muamalah mempunyai 
pengertian, "saling memikul resiko di antara sesama orang sehingga antara satu dengan lainnya menjadi penggung atas resiko lainnya. Saling pikul resiko itu dilakukan atas dasar saling tolong dalam kebaikan dengan cara masing-masing mengeluarkan dana ibadah (tabarra) yang ditunjukkan untuk menanggung resiko tersebut."

Adapun yang menjadi perbedaan pokok antara asuransi takaful dengan asuransi konvensional lainnya adalah para peserta saling bertanggung jawab di antara mereka sendiri. (Forum Keadilan No. 15 Tahun II : 68).

Menurut praja (1994:1), ada beberapa unsur yang harus ada demi terlaksananya takaful, yaitu dua atau beberapa pihak yang bertakaful, juga pengelola takaful.

Dalam asuransi takaful terdapat prinsip-prinsip yang harus ditegakkan. Asuransi takaful (Basyir, 1993:15) tegak atas tiga prinsip yaitu sebagai berikut:

a. Saling Bertanggung Jawab.

b. Saling bekerja sama dan Bantu membantu.

c. Saling menjaga keselamatan dan keamanan. 
Di samping itu Juhaya S. Praja mengatakan bahwa takaful didasarkan atas prinsip-prinsip sebagai berikut:

a. Prinsip Tauhid.

b. Prinsip saling menyayangi sesama muslim dan manusia.

c. Prinsip saling membantu sesame muslim dan manusia.

d. Saling melindungi dan mengambil alih atau memikul penderitaan atau resiko yang diderita sesama muslim dan manusia umumnya berdasarkan prinsip-prinsip di atas (1-3).

Ahmad Azhar Basyir, "Berpendapat bahwa prinsip asuransi takaful adalah "penghayatan semangat saling bertanggung jawab, kerja sama dan perlindungan dalam kegiatan-kegiatan sosial menuju tercapainya kesejahteraan ummat dan persatuan masyarakat".

Jenis-Jenis Asuransi Takaful ada dua, yaitu sebagai berikut:

a. Takaful Keluarga.

b. Takaful Umum. 


\section{Pasar Modal Islami.}

Nash yang terang tentang hal ini dalam alQur'an dan hadits tidak dijumpai. Namun demikian, jul beli saham tidak bertentangan dengan hokum Islam. Akan tetapi, perlu dicatat bahwa kebolehan jaual beli saham tersebut hanya sebatas saham-saham yang bidang usahanya tidak bertentangan dengan dengan syari'at Islam.Khusus pasar modal di Malaysia telah dimulai operasinya sejak tahun 1994 dan demikian juga di Sudan. Pasar modal Islami sama dengan pasar modal biasa namun pasar ini surat berharga atau saham yang diperdagangkan harus sesuai dengan syari'at Islam dan perusahaan yanag memperdagangkan sahamnya harus perusahaan yang tidak menyalahi hokum syariah. Sesuai dengan syariah Islam berarti tidak boleh ada penipuan, kezaliman, unsur riba, dan transaksi yang tidak jujur lainnya. 


\section{Bank Muamalat Indonesia.}

Bank Muamat berdiri pada tanggal 1 November 1991.bank Muamalat ini memiliki prinsip antara lain sebagai berikut:
a. Sistem Bagi hasil.
b. Sistem Jual beli.
c. Sistem fee (jasa).

Produk dan jasa PT Bank Muamalat Indonesia adalah sesuai dengan prinsip-prinsip Peraturan Pemerintah Nimor 72 Tahun 1992, yaitu Sebagai berikut:

\section{Produk Pemupukan Dana Masyarakat.}

a. Giro Wadiah.

b. Deposito bagi hasil Mudharabah.

c. Tabungan bagi hasil Mudharabah.

\section{Produk Penyaluran Dana.}

a. Pembiayaan bagi hasil Mudharabah.

b. Pembiayaan Modal Kerja Murabahah.

c. Pembiayaan investasi al-Abithaman Ajil.

\section{Jasa-Jasa Perbankan.}
a. Jual beli valas : Al-Sharf.
b. Jasa Pemberian Jaminan : Al-Kafalah.
c. Jasa Penerbitan L/C : Al-Wakalah.
d. Jasa Pengalihan Tagihan : Al-Hiwalah. 


\section{Kepedulian Sosial PT Bank Muamalat}

Indonesia.

a. Zakat BMI (dalam bentuk Qardhul Hasan).

b. Ashnaf (amal Shadaqah).

c. Setoran Titipan Zakat (Zakat perusahaan dan penghasilan).

d. Perhitungan Zakat Perusahaan BMI (2,5 $\%$ dari laba perseroan perusahaan setelah pajak).

\section{Sistem Operasional Perbankan Syariah}

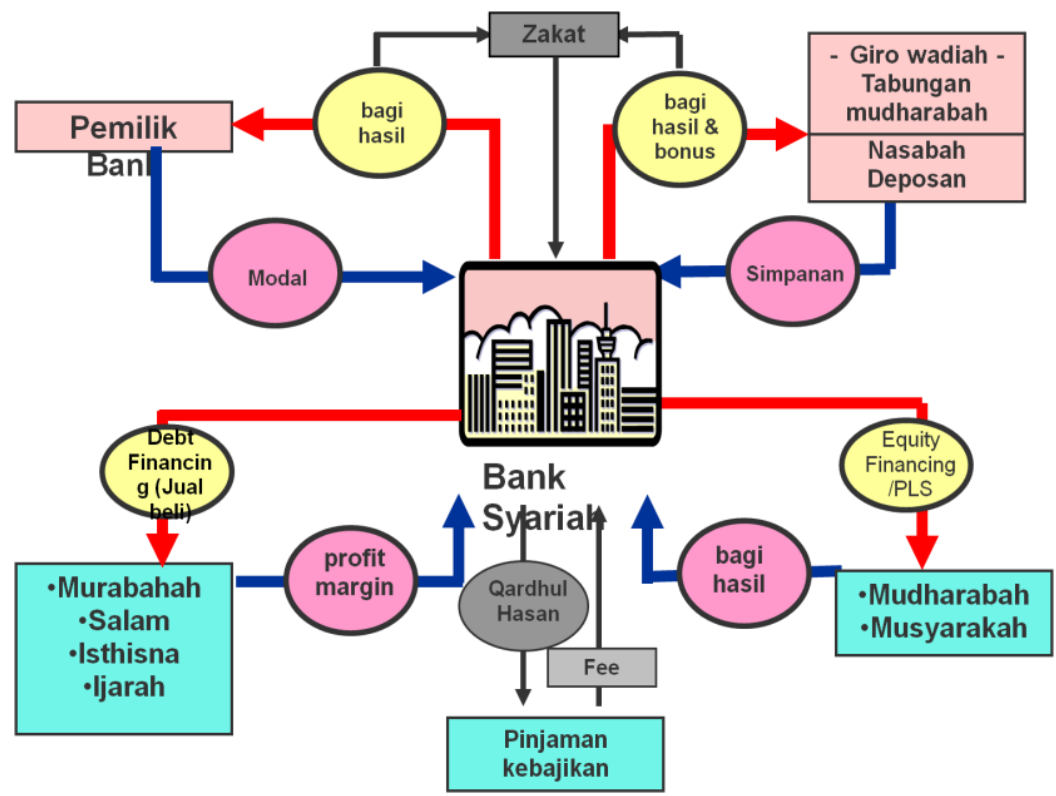




\section{Perbedaan dan Persamaan Perbankan Syariah (bagi hasil) dan Konvensional (bunga)}

\begin{tabular}{|c|c|c|}
\hline No & Bagi Hasil & Bunga \\
\hline 1 & $\begin{array}{l}\text { melakukan investasi- } \\
\text { investasi yang halal saja }\end{array}$ & $\begin{array}{l}\text { investasi yang halal } \\
\text { dan haram }\end{array}$ \\
\hline 2 & $\begin{array}{l}\text { profit dan falah oriented } \\
\text { dunia akhirat kelak }\end{array}$ & $\begin{array}{l}\text { profit oriented dan } \\
\text { cenderung } \\
\text { mementingkan dunia } \\
\text { dan mengabaikan } \\
\text { akhirat kelak }\end{array}$ \\
\hline 3 & $\begin{array}{l}\text { hubungan dengan nasabah } \\
\text { dalam bentuk hubungan } \\
\text { kemitraan }\end{array}$ & $\begin{array}{l}\text { hubungan dengan } \\
\text { nasabah dalam bentuk } \\
\text { hubungan debitor- } \\
\text { kreditor }\end{array}$ \\
\hline 4 & 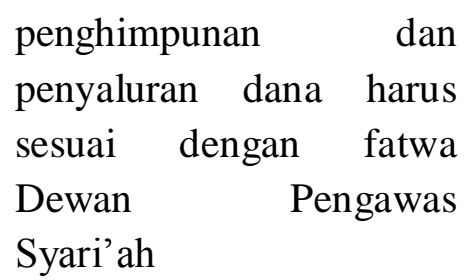 & $\begin{array}{l}\text { tidak terdapat dewan } \\
\text { sejenis }\end{array}$ \\
\hline 5 & $\begin{array}{l}\text { penentuan besarnya } \\
\text { rasio/nisbah bagi hasil } \\
\text { dibuat pada waktu akad } \\
\text { dengan berpedoman pada } \\
\text { kemungkinan untung rugi. }\end{array}$ & $\begin{array}{l}\text { penentuan } \\
\text { dibuat pada waktu } \\
\text { akad dengan asumsi } \\
\text { harus selalu untung }\end{array}$ \\
\hline 6 & besarnya rasio bagi hasil & persentase \\
\hline
\end{tabular}




\begin{tabular}{|c|l|l|}
\hline & $\begin{array}{l}\text { berdasarkan pada jumlah } \\
\text { keuntungan } \\
\text { diperoleh. }\end{array}$ & $\begin{array}{l}\text { berdasarkan pang } \\
\text { jumlah uang (modal) } \\
\text { yang dipinjamkan }\end{array}$ \\
\hline $\mathbf{7}$ & $\begin{array}{l}\text { besarnya bagi hasil } \\
\text { tergantung pada } \\
\text { keuntungan / kerugian } \\
\text { proyek yang dijalankan. }\end{array}$ & $\begin{array}{l}\text { pembayaran bunga } \\
\text { tetap seperti yang } \\
\text { diperjanjikan, tanpa } \\
\text { menimbang apakah } \\
\text { proyek untung atau } \\
\text { rugi. hasil }\end{array}$ \\
\hline $\mathbf{8}$ & $\begin{array}{l}\text { meningkat sesuai dengan } \\
\text { meningkatnya jumlah } \\
\text { pendapatan. }\end{array}$ & $\begin{array}{l}\text { jumlah pembayaran } \\
\text { bunga tidak meningkat } \\
\text { sekalipun jumlah } \\
\text { keuntungan meningkat. }\end{array}$ \\
\hline $\mathbf{9}$ & $\begin{array}{l}\text { tidak ada yang meragukan } \\
\text { keabsahan bagi hasil. }\end{array}$ & $\begin{array}{l}\text { keberadaan bunga } \\
\text { dikecam oleh seluruh } \\
\text { agama, termasuk } \\
\text { Islam. }\end{array}$ \\
\hline
\end{tabular}

\section{Inti Dasar Konsep Akuntansi Islam}

Karena akuntansi ini sifatnya urusan muamalah maka pengembangannya diserahkan pada kebijakan manusia. Al-Qur'an dan sunnah hanya membekalinya dengan beberapa system nilai seperti landasan etika moral, kebenaran, keadilan, kejujuran, terpercaya, bertanggung jawab, dan sebagainya. 
Dalam Al-Qur'an surat Al-Baqarah kita melihat bahwa tekanan Islam dalam kewajiban melakukan pencatatan adalah:

1. Menjadi bukti dilakukannya transaksi (muamalah) yang menjadi dasar nantinya dalam menyelesaikan persoalan selanjutnya.

2. Menjaga agar tidak terjadi manipulasi, atau penipuan baik dalam transaksi maupun hasil dari transaksi itu (laba).

Penekanan ini didukung lagi oleh ayat-ayat yang dapat dijadikan sumber moral akuntansi seperti kewajiban bertaqwa, berlaku adil, jujur, menyatakan yang benar, memilih yang terbaik, berguna, menghindari yang haram, jangan boros, jangan merusak, jangan menipu, dan lain sebagainya. Dan yang sifatnya tekhnis diserahkan sepenuhnya kepada ummatnya untuk merumuskannya sesuai kebtuhannya.

Scott (Harahap, 1993, 1995) adalah seorang penulis yang banyak memperhatikan masalah etika dan moral dalam melahirkan teori akuntansi.Ia selalu menggunakan criteria keadilan dan kebenaran dalam merumuskan setiap teori akuntansi, model ini disebut Ethical Theory of Accaounting. Menurut beliau dalam penyajian laporan 
keuangan, akuntan harus memperhatikan semua pihak (user) dan memperlakukannya secara adil dan benar.Dan memberikan data yang akurat jangan menimbulkan salah tafsir dan jangan pula bias. Shaari Hamid, Russel Craig dan Frank Clarke (1993) dalam artikel mereka berjudul:

"Religion: A Counfounding CulturalElement in the Int ernational Harmonization of Accounting" mengemukakan dua hal:

1. Bahwa Islam sebagai agama yang memiliki aturanaturan khusus dalam system ekonomi keuangan (misalnya free interest banking system) pasti memerlukan teori ekuntansi yang khusus pula yang dapat mengakomodasi ketentuan syariah itu.

2. Kalau dalam berbagai studi disimpulkan bahwa aspek budaya yang bersifat local sangat banyak mempengaruhi perkembangan akuntansi, maka Islam sebagai agama yang melampaui batas negara tidak boleh diabaikan. Islam dapat mendorong internasionalisasi dan harmonisasi akuntansi.

Muhammad Akram Khan (harahap, 19932l2) merumuskan sifat akuntansi islam sebagai berikut:

1. Penentuan laba rugi yang tepat. 
2. Mempromosikan dan menilai efisiensi kepemimpinan.

3. Ketaatan kepada hukum syari'ah.

4. Keterikatan pada keadilan.

5. Melaporkan dengan baik.

6. Perubahan dalam praktek akuntansi.

\section{EVALUASI}

\section{Jawab dan Diskusikan pertanyaan dibawah ini ;}

1. Sebut dan Jelaskan macam dan jenis lembaga keuangan syariah yang ada di Indonesia.

2. Jelaskan system operasional perbankan syariah.

3. Jelaskan persamaan dan perbedaan perbankan syariah dan konvensional. 


\section{BAGIAN 3 \\ TEORI AKUNTANSI ISLAM}

\section{Tujuan Instruksional Umum}

1. Memahami konsep yang melatar belakangi lahirnya akuntansi Syariah.

2. Menjelaskan peranan Akuntansi Syariah dalam organisasi dan peranan informasi bagi manajer

3. Mengetahui peran akuntan Syariah

4. Menjelaskan perspektif akuntansi Syariah dan menjelaskan peranan Akuntansi Syariah

5. Membedakan antara akuntansi Syariah dan Akuntansi konvensional

\section{SUB POKOK BAHASAN}

\section{Beberapa Dimensi Akuntansi Menurut Alquran,} Ilahiyah, Sejarah Islam, dan Kini

\section{A. Pengertian Akuntansi}

Pengertian akuntansi konvensional menurut Accounting Principle Board (APB) Statement No.4 (Belkaoui,1985): 
"Akuntansi adalah suatu kegiatan jasa.Fungsinya adalah memberikan informasi kuantitatif, umumnya dalam ukuran uang, mengenai suatu badan ekonomi yang dimaksudkan untuk digunakan dalam pengambilan keputusan ekonomi sebagai dasar memilih di antara beberapa alternatif."

American Accounting Association mendefinisikan akuntansi sebagai:

“.... Proses mengidentifikasikan, mengukur, dan melaporkan informasi ekonomi, untuk memungkinkan adanya penilaian dan keputusan yang jelas dan tegas bagi mereka yang menggunakan informasi tersebut".

Tujuan utama akuntansi adalah menyajikan informasi ekonomi dari suatu kesatuan ekonomi kepada pihak-pihak yang berkepentingan.Dalam buku ini yang dimaksud dengan kesatuan ekonomi adalah badan usaha.Informasi ekonomi yang dihasilkan oleh akuntansi berguna bagi pihak-pihak dalam perusahaan itu sendiri maupun pihak-pihak di luar perusahaan.

Untuk menghasilkan informasi ekonomi, perusahaan perlu menciptakan suatu metode pencatatan, 
penggolongan, analisis, dan pengendalian transaksi serta kegiatan-kegiatan keuangan, kemudian melaporkan hasilnya. Kegiatan akuntansi meliputi:

- Pengidentifikasian dan pengukuran data yang relevan untuk suatu pengambilan keputusan.

- Pemprosesan data yang bersangkutan kemudian pelaporan informasi yang dihasilkan.

- Pengkomunikasian informasi kepadapemakai laporan.

B. Pengertian Syariah

Dalam KDPPLK - Pengertian Syariah merupakan ketentuan hukum Islam yang mengatur aktivitas manusia yang berisi perintah dan larangan, baik yang menyangkut hubungan interaksi vertikal dengan Tuhan maupun interaksi horisontal dengan sesama makhluk

\section{Akuntansi (kapitalis) dalam Al-Qur'an}

Akuntansi yang terdapat dalam Al-Qur'an terdapat dalam surah Al-Baqarah ayat 282: 


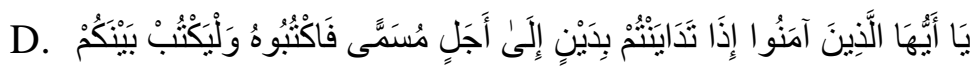

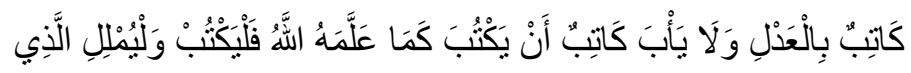

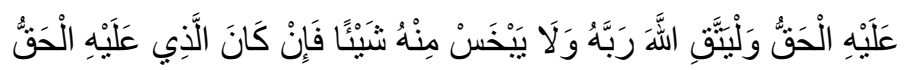

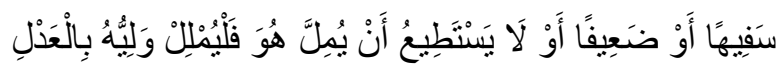

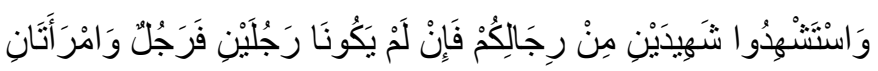

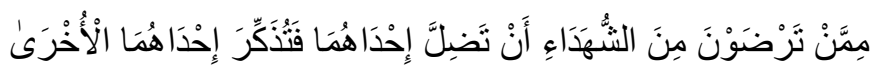

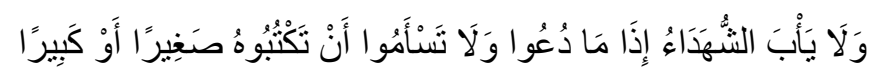

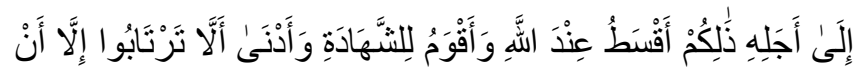

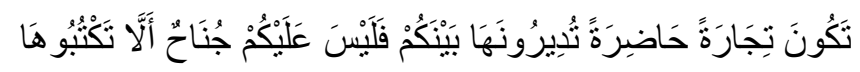

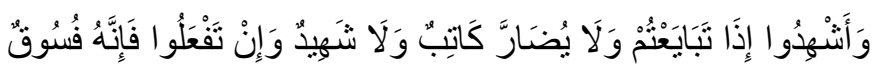

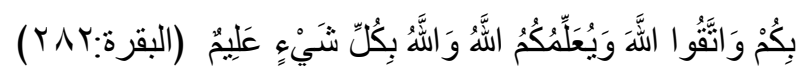

"Hai orang-orang yang beriman, apabila kamu bermualmalah tidak secara tunai untuk waktu yang ditentukan, hendaklah seorang penulis di antara kamu menuliskannya dengan benar. Dan janganlah penulis enggan menuliskannya sebagaimana Allah telah mengajarkannya, maka hendaklah ia menulis, dan hendaklah ia orang yang berhutang itu mengimlakkan apa yang ditulisnya itu, dan hendaklah ia bertakwa kepada Allah Tuhannya, dan janganlah ia mengurangi sedikitpun daripada utangnya. Jika yang berutang itu orang yang lemah akal atau lemah keadaannya atau dia sendiri tidak 
maтри mengimlakkan, maka hendaklah wakilnya mengmlakkan dengan jujur dan persaksikanlah dengan dua orang saksi dari orang laki-laki diantara kamu. Jika tidak ada dua orang laki-laki maka bolehlah seorang laki-laki dan dua orang perempuan dari saksi yang kamu ridhoi, supaya jika seorang lupa seorang lagi mengingatnya”.

\section{E. Akuntansi Ilahiyah}

Allah adalah Maha Akuntan, karena dia Maha Cepat (Hasib) perhitungannya, mencatat semua kejadian, dari yang besar sampai yang kecil. Seperti yang terdapat dalam Al-Qur'an surah Al-Baqarah :202 dan surah An-nisa':86

\section{F. Akuntansi dalam Sejarah Islam}

Belum banyak leteratur dalam bahasa Inggris yang kita peroleh untuk membahas isu Akuntanasi dalam sejarah islam, diharapkan dalam perjalanan waktu hal ini akan banyak diungkapkan dengan penerjemahan buku-buku Arab kedalam bahasa Inggris atau Indonesia. Disini kita kan mencoba melihat bagaimana praktek akuntansi (sejauh yang 
ada dalam literature) di negara yang dapat dikategorikan sebagai negara yang islamnya dominan. Studi mengenai topik ini belum banyak sehingga barangkali analisa kita juga belum lengkap. Kita perlu mengarahkan penelitian kita untuk mengali praktek akuntansi dinegara atau di masyarakat yang hukum sosialnya menerapkan dasar islam. Khususnya selama kurun waktu kejayaan islam sejak zaman Rasulullah sampai abad ke 10 Masehi.

Penulisan akuntansi islam dalam lintasan sejarah ini diawali dari masa Pra islam, Masa Rasulullah SAW ( 1 - 23 H), Masa Khulafa Rasyidin, yaitu Abu Bakar Siddik (632 - 634 M), Masa Umar Bin Khattab ( 634 - 644 M), Masa Ustman Bin Affan (644 - 655 M), serta Masa Ali Bin Abi Thalib (655 $661 \mathrm{M})$. Setelah masa pra islam, Rasulullah dan Masa Khulafa Rasyidin tersebut, maka penulisan akan dilanjutkan kemasa Umayah (661 - 750 M), lebih kurang selama 90 tahun, kemudian Masa Abbasiyah (750 - $1258 \mathrm{M})$, dan terakhir akan dilanjutkan pada masa Ustmani yaitu kekhalifahan terakhir umat islam sebelum dihancurkan oleh sekulerisme yaitu dari 
tahun 1258 sampai dengan tahun runtuhnya khilafah Ustmani yaitu tahun 1924M.

\section{Prinsip-prinsip Akuntansi Islam}

Adapun prinsip akuntansi syariah yang diperkenalkan oleh Islam secara garis besarnya adalah sebagai berikut:

1. Transakasi yang menggunakan prinsip bagi hasil seperti mudharabah dan musyarakah.

2. Transaksi yang menggunakan prinsip jual beli seperti murabahah, salam dan istishna.

3. Transaksi yang menggunakan prinsip sewa, seperti ijarah

4. Transaksi yang mengunakan prinsip titipan, seperti wadiah

5. Transaksi yang menggunakan prinsip penjaminan, seperti rahn

Prinsip Umum Akuntansi Islam, Berdasarkan Surat Al Baqarah 282 : 


\section{Prinsip}

Pertanggungjawaban

\section{(accountability)}

Implikasi dalam bisnis dan akuntansi adalah bahwa individu yang terlibat dala praktik bisnis harus selalu melakukan pertanggungjawaban apa yang telah diamanatkan dan diperbuat kepada pihakpihak yang terkait.

\section{Prinsip Keadilan}

Dalam konteks akuntansi, menegaskan, kata adil dalam ayat 282 surat Al-Baqarah, secara sederhana dapat berarti bahwa setiap transaksi yang dilakukan oleh perusahan harus dicatat dengan benar. Dengan kata lain tidak ada window dressing dalam praktik akuntansi perusahaan.

\section{Prinsip Kebenaran}

Dalam akuntansi selalu dihadapkan pada masalah pengakuan \& pengukuran laporan. Aktivitas ini akan dapat dilakukan dengan baik apabila dilandaskan pada nilai kebenaran. Kebenaran ini akan dapat menciptakan nilai 
keadilan dalam mengakui, mengukur, dan melaporkan tansaksi-transaksi dalam ekonomi. Menurut pandangan beberapa kalangan yang lain akuntansi Islam (syari'ah) mempunyai prinsip-prinsip sebagai berikut adalah:

1. Prinsip Legitimasi Muamalat, yaitu sasaransasaran, transaksi-transaksi, tindakan-tindakan dan keputusan-keputusan itu sah dan benar menurut syariat.

2. Prinsip Entitas Spiritual, adalah adanya pemisahan kegiatan investasi daripribadi yang melakukan pendanaan terhadap kegiatan investasi dalam aktivitas perusahaan.

3. Prinsip Kontinuitas, yaitu prinsip yang keberadaanya dapat memberikanpandangan bahwa perusahaan itu akan terus menjalankan kegiatannya sampai waktu yang tidak diketahui, dan dilikuidasinya merupakan masalah pengecualian, kecuali jika terdapat indikasi yang mengarah kepada kebalikannya.

4. Prinsip Kontinuitas (Going Concern), merupakan kaidah umum dalam investasi. 
Prinsip ini menjadi dasar dalam pengambilan keputusan agar perusahan terus beroperasi.

5. Prinsip Matching, yaitu suatu cermin yang memantulkan hubungan sebab akibat antara dua sisi, dari satu segi, dan mencerminkan juga hasil atau dari hubungan tersebut dari segi lainnya.

\section{Perubahan Revolusi Kuhn dan Perkembangan}

\section{Akuntansi Islam}

Telah banyak perusahaan di Indonesia yang mengalami akuisisi dan merger lintas negara. Misal, akuisisi Philp Morris terhadap Sampoerna (2005), akuisisi TPI oleh MNC TV (2009), dan ANTV oleh Star TV. Aktivitas akuisisi dan merger lintas negara bukanlah hal yang tabu pada saat ini, sebagaimana yang dikatakan oleh Thomas Friedman, "world is flat".

Perubahan konseptual yang dialami oleh dunia akuntansi di Indonesia, tentu akan menimbulkan dampak yang bermacam-macam bagi perkembangan ilmu akuntansi di Indonesia. Menurut Ketua Tim Implementasi IFRS-IAI, Dudi M. Kurniawan (Kompas, 6 Mei 2010) bahwa dengan mengadopsi 
IFRS, Indonesia akan mendapatkan tujuh manfaat sekaligus. Pertama, meningkatkan standar akuntansi keuangan (SAK).Kedua, mengurangi biaya SAK.Ketiga, meningkatkan kredibilitas dan kegunaan laporan keuangan.Keempat, meningkatkan komparabilitas pelaporan keuangan.Kelima, meningkatkan transparansi keuangan. Keenam, menurunkan biaya modal peluang penghimpunan dana melalui pasar modal. Ketujuh, meningkatkan efisiensi penyusunan laporan keuangan.

Namun dalam praktiknya, menerapkan standar baru ini tidaklah mudah.Banyak pelaku bisnis yang mengeluhkan kesulitan dalam penerapan standar baru tersebut di perusahaannya.Biaya yang harus dikeluarkan untuk investasi di bidang teknologi dan informasi untuk mendukung penerapan IFRS tidaklah sedikit.Belum lagi ditambah dengan biaya-biaya pelatihan (training) IFRS bagi karyawan juga tidaklah sedikit.Sekedar informasi, biaya inventasi untuk training IFRS berkisar antara 3 juta sampai 5 juta per orang.Tentu saja bukan biaya yang murah bagi perusahaan berskala menengah. 
Pemerintah juga harus ikut berperan dalam penerapan IFRS di Indonesia.Terutama di bidang perpajakan yang berkaitan dengan revaluasi aktiva sebagai konsekuensi dari penerapan fair value.Pemerintah masih memberlakukan pajak final sebesar $10 \%$ atas transaksi revaluasi atas aktiva tetap.Dengan fair value, berarti nilai aset dihitung berdasarkan harga pasar. Ini berarti, aset-aset perusahaan akan cenderung mengalami kenaikan dan perusahaan berkewajiban membayar pajak final $10 \%$ atas revaluasi aktiva tetap. Mungkinkan perusahaan bersedia membayar pajak final, padahal tidak ada aliran kas masuk yang berarti.

Sejak tahun 2004, IAI telah melakukan harmonisasi (konvergensi) antara GAAP dan IFRS untuk mencapai daya saing global. Diharapkan pada tahun ini perbedaan antara GAAP dan IFRS dapat diselesaikan dan IFRS pun dapat diterapkan sepenuhnya. 


\section{Prinsip-Prinsip Akuntansi Islam}

Prinsip-prinsip akuntansi islam ada 9 yaitu :

\section{Kebebasan Individu}

Kebebasan merupakan modal utama bagi muslim untuk membentuk kehidupan ekonomi yang Islami. Tanpa kebebasan seorang muslim tidak dapat melaksanakan kewajiban mendasar sebagai seorang khalifah, Kebebasan manusia yang didasarkan atas pengabdian kepada Allah akan membedakan keberanian dan kepercayaan diri.

maka dari itu Islam menjamin kebebasan individu sepanjang kebebasan tersebut tetap dalam bingkai syari'ah Islam. Kepentingan masyarakat yang lebih luas harus didahulukan dari kepentingan individu.

Melepas kesulitan harus diprioritaskan dibanding memberi manfaat, meskipun kedua-duanya sama merupakan tujuan syari'ah, Kerugian yang lebih besar tidak dapat diterima untuk menghilangkan yang lebih kecil.

Qalbu memanage otak dan nafsu bukan seblaiknya nafsu memanage otak dan kalbu 
(Lihat: An Nisaa':85, Al Muddatsir:38, dan An Najm:39)

\section{Hak dan kepemilikan terhadap harta}

Kekayaan merupakan amanah Allah yang diberikan kepada manusia untuk dipergunakan untuk kebaikanPemilikan hanya atas manfaatnya. Pengelolaan harta yang menjadi hak milik harus memberikan manfaat bagi diri sendiri dan orang lain maupun kepentingan umum, tidak boleh berlebihanlebihan dan melampaui batas

Hakekat kepemilikan Harta adalah hakekatnya milik Allah SWT, sedangkan kepemilikan pada manusia hanyalah titipan dan amanah yang bertugas sebagai pengelola dan memanfaatkannya demi Falah dunia akhirat sehingga wajib mengikuti apa-apa yang disyariahkan oleh pemilik-Nya yang sewaktu-waktu akan diambil oleh pemiliknya, baik didahului dengan isyarat maupun tidak tergantung kehendak pemiliknya. (Lihat QS; Al Hadiid:7, An Nissaa':5\&29, AL Baqarah:29) 


\section{Keseimbangan dan Keselarasan}

- Sederhana

- Hemat

- Menjauhi pemborosan

\section{Keadilan dan Kesamaan Sosial}

Keadilan dan Kesamaan Sosial Berarti kebebasan bersyarat akhlak Islam yang harus diterapkan di semua fase kegiatan ekonomi sehingga dapat di Alokasikan sejumlah hasil kepada yang tak mampu masuk pasar atau tak sanggup membeli menurut kekuatan pasar.

\section{Ketidaksamaan Ekonomi yang Wajar}

Islam mengakui adanya ketidaksamaan ekonomi diantara orang perorang dan Islam tidak mengajurkan kesamaan ekonomi, tetapi ia mendukung dan menggalakkan kesamaan sosial, sehingga Islam tidak mengajurkan adanya perbedaan pemberlakuan antara sesamanya, satu dengan yang lain mempunyai hak dan kewajiban ekonomi sama dalam meningkatkan kesejahteraannya. Agar tercipta Kesamaan sosial ini membentuk keharmonisan dalam kehidupan manusia. 
(Lihat QS : AZ Zukhruf:32, An Aam:165, Al Harsyr:7, An Nisaa':32, 135,AL Maidah:8dan HUd:85 )

\section{Jaminan Sosial}

Setiap individu mempunyai hak untuk hidup dalam sebuah negara; dan setiap warga negara dijamin untuk memperoleh kebutuhan pokoknya masingmasing. Tugas dan tanggungjawab utama bagi sebuah negara adalah menjamin setiap warga negaranya dalam memenuhi kebutuhan sesuai dengan prinsip "hak untuk hidup"

- Islam menjamin kehidupan seluruh masyarakat untuk mendapatkan kesejahteraan yang sama:ZIS.

- Keuntungan dan beban sebanding dengan manfaat: (17:15)

- Tidak boleh ada eksternalitas negatif: (2:279).

- Manfaat dari sumber2 ekonomi harus dapat dinikmati oleh seluruh makhluk (2:22 dan 29). (Lihat QS : Adz Dzaariyaat:19) 


\section{Distribusi Kekayaan}

Sumberdaya alam adalah hak manusia untuk dipergunakan bagi kemaslahatannya, upaya ini tidak akan menjadi masalah bila tidak ada usaha untuk mengoptimalkan segala aspek ekonomi yang ada, sehingga Islam mencegah penumpukan kekayaan pada sekelompok kecil masyarakat dan menganjurkan distribusi kekayaan kepada semua lapisan masyarakat. (Lihat QS : An Nahl:71 )

\section{Larangan Menumpuk (Menimbun) Harta}

Sistem ekonomi Islam melarang individu mengumpulkan harta kekayaan secara berlebihan. Sikap sederhana dan tidak melampaui batas dalam memiliki materi merupakan sikap manusia yang sehat karena Menimbun harta secara berlebihan dilarang karena akan merusak mekanisme pasar. (Lihat QS : Al Maidah:87, Al Humazah:1-4, Al Baqarah:143)

9. Kesejahteraan Individu dan Masyarakat Dunia Akhirat

Kehidupan individu dan masyarakat saling berkaitan antara satu dengan yang lain sehingga Kepentingan 
individu tidak boleh bertentangan dengan kepentingan masyarakat dan sebaliknya. Islam menghendaki terwujudnya perekonomian yang memenuhi kebutuhan semua orang, pembagian pendapatan dan kekayaan yang adil, pemberian kesempatan kerja penuh, setiap individu mendapatkan haknya sesuai dengan kontribusi (kewajiban) masing-masing, tidak ada eksploitasi individu oleh individu lainnya dan perlindungan alam sekitar. ( Lihat QS : Al Qashash:77 )

\section{Perubahan Revolusi Kuhn dan Perkembangan Akuntansi}

\section{Islam}

Telah banyak perusahaan di Indonesia yang mengalami akuisisi dan merger lintas negara. Misal, akuisisi Philp Morris terhadap Sampoerna (2005), akuisisi TPI oleh MNC TV (2009), dan ANTV oleh Star TV. Aktivitas akuisisi dan merger lintas negara bukanlah hal yang tabu pada saat ini, sebagaimana yang dikatakan oleh Thomas Friedman, "world is flat".

Perubahan konseptual yang dialami oleh dunia akuntansi di Indonesia, tentu akan menimbulkan dampak yang bermacam-macam bagi perkembangan ilmu akuntansi di 
Indonesia. Menurut Ketua Tim Implementasi IFRS-IAI, Dudi M. Kurniawan (Kompas, 6 Mei 2010) bahwa dengan mengadopsi IFRS, Indonesia akan mendapatkan tujuh manfaat sekaligus. Pertama, meningkatkan standar akuntansi keuangan (SAK).Kedua, mengurangi biaya SAK.Ketiga, meningkatkan kredibilitas dan kegunaan laporan keuangan.Keempat, meningkatkan komparabilitas pelaporan keuangan.Kelima, meningkatkan transparansi keuangan. Keenam, menurunkan biaya modal peluang penghimpunan dana melalui pasar modal. Ketujuh, meningkatkan efisiensi penyusunan laporan keuangan.

Namun dalam praktiknya, menerapkan standar baru ini tidaklah mudah.Banyak pelaku bisnis yang mengeluhkan kesulitan dalam penerapan standar baru tersebut di perusahaannya.Biaya yang harus dikeluarkan untuk investasi di bidang teknologi dan informasi untuk mendukung penerapan IFRS tidaklah sedikit.Belum lagi ditambah dengan biaya-biaya pelatihan (training) IFRS bagi karyawan juga tidaklah sedikit.Sekedar informasi, biaya inventasi untuk training IFRS berkisar antara 3 juta sampai 5 juta per orang.Tentu saja bukan biaya yang murah bagi perusahaan berskala menengah. 
Pemerintah juga harus ikut berperan dalam penerapan IFRS di Indonesia.Terutama di bidang perpajakan yang berkaitan dengan revaluasi aktiva sebagai konsekuensi dari penerapan fair value. Pemerintah masih memberlakukan pajak final sebesar $10 \%$ atas transaksi revaluasi atas aktiva tetap.Dengan fair value, berarti nilai aset dihitung berdasarkan harga pasar. Ini berarti, aset-aset perusahaan akan cenderung mengalami kenaikan dan perusahaan berkewajiban membayar pajak final $10 \%$ atas revaluasi aktiva tetap. Mungkinkan perusahaan bersedia membayar pajak final, padahal tidak ada aliran kas masuk yang berarti.

Sejak tahun 2004, IAI telah melakukan harmonisasi (konvergensi) antara GAAP dan IFRS untuk mencapai daya saing global. Diharapkan pada tahun ini perbedaan antara GAAP dan IFRS dapat diselesaikan dan IFRS pun dapat diterapkan sepenuhnya.

\section{Akuntansi Islam: Munculnya Era Epistemologi Islam}

Kerangka konseptual akuntansi syariah sebagaimana telah dikemukakan di atas dirumuskan menggunakan pendekatan epistimologi Islam.Epistimologi adalah cabang filsafat yang secara khusus membahas teori ilmu pengetahuan, secara harfiah epistimologi berasal dari bahasa 
Yunani episteme yang berarti pengetahuan (Suria Sumantri, 1991). Dalam lingkup filsafat ilmu, epistimologi mengandung pengertian sebagai metode memperoleh pengetahuan agar memiliki karakteristik, kebenaran, dan nilai-nilai tertentu sebagai ilmu (Chalmers, 1991). Dalam konteks epistimologi sebagai metode memperoleh pengetahuan ilmu, epistimologi Islam diperlukan guna memperoleh pengetahuan yang diharapkan memiliki karakteristik, kebenaran dan nilai-nilai Islami. Epistimologi Islam adalah metode memperoleh pengetahuan ilmu yang Islami melalui proses penalaran yang sistematis, logis dan sangat mendalam menggunakan "ijtihad" yang dibangun atas kesadaran sebagai khalifatullah fii-ardl (lihat Syafi'i, 2000 dan Triyuwono, 2000).

Prinsip dasar paradigma syariah merupakan multi paradigma yang holistic, mencakup keseluruhan dimensi wilayah mikro dan makro dalam kehidupan manusia yang saling terkait. Pertama, dimensi mikro prinsip dasar paradigma syariah adalah individu yang beriman kepada Allah SWT (tauhid) serta mentaati segala aturan dan larangan yang tertuang dalam Al-Qur'an,Al Hadits, Fiqh, dan hasil ijtihad. Landasan tauhid diperlukan untuk mencapai tujuan syariah yaitu menciptakan keadilan sosial (al a'dl dan al ihsan) serta kebahagiaan dunia dan akhirat. Pencapaian tujuan 
syariah tersebut dilakukan menggunakan etika dan motal iman (faith), taqwa (piety), kebaikan (righteoneus/birr), ibadah (worship), tanggungjawab (responsibility/fardh), usaha (free will/ikhtiyar), hubungan dengan Allah dan manusia (Habluminallah dan Habluminannas), serta barokah (blessing).

Kedua, dimensi makro prinsip syariah adalah meliputi wilayah politik,ekonomi dan sosial. Dalam dimensi politik, menjunjung tinggi musyawarah dan kerjasama.Sedangkan dalam dimensi ekonomi, melakukan usaha halal, mematuhi larangan bunga, dan memenuhi kewajiban zakat.Selanjutnya dalam dimensi sosial yaitu mengutamakan kepentingan umum dan amanah.

Dalam kerangka konseptual akuntansi syariah tersebut di atas, dinyatakan bahwa tujuan diselenggarakannya akuntansi syariah adalah mencapai keadilan sosial-ekonomi; dan sebagai sarana ibadah memenuhi kewajiban kepada Allah SWT, lingkungan dan individu melalui keterlibatan institusi dalam kegiatan ekonomi.Produk akhir teknik akuntansi syariah adalah informasi akuntansi yang akurat untuk menghitung zakat dan pertanggungjawaban kepada Allah SWT dengan berlandaskan moral, iman dan taqwa. 
Dengan demikian dalam hal akuntansi syariah sebagai alat pertanggungjawaban, diwakili informasi akuntansi syariah dalam bentuk laporan keuangan yang sesuai dengan syariah yaitu mematuhi prinsip full disclousure. Laporan keuangan akuntansi syariah tidak lagi berorientasi pada maksimasi laba, akan tetapi membawa pesan modal dalam menstimuli perilaku etis dan adil terhadap semua pihak.

Jenis laporan keuangan akuntansi syariah yang memenuhi criteria ini menurut Harahap (2000) meliputi :

a. Neraca, yang menyajikan pula Laporan Sumberdaya Manusia.

b. Laporan Nilai Tambah (Value Added Reporting) yang menyajikan semua hasil yang diperoleh perusahaan darikontribusi semua pihak yang terkait dengan entitas, dan kemudian mendistribusikannya secara adil.

c. Laporan Arus Kas (Cash Flow).

d. Laporan Pertanggungjawaban Sosial Perusahaan (Socio Economy Accounting Reporting).

e. Catatan atas Laporan Keuangan, mengenai implementasi syariah misalnya zakat, infaq, shodaqoh, transaksi haram, dan laporan dewan syariah.Melaporkan good governance, mengenai 
produksi, efisiensi, produktivitas, dan laporan lainnya yang relevan.

\section{Akuntansi Sosial Ekonomi dan Akuntansi Islam Akuntansi Sosial Ekonomi}

Akuntansi Social Ekonomi (ASE) menurut Belkaoui (1984) lahir dari anggapan bahwa akuntansi sebagai alat manusia dalam kehidupannya harus juga sejalan dengan tujuan social hidup manusia.ASE berfungsi untuk memberikan informasi "social report" tentang sejauh mana unit organisasi, Negara dan dunia memberikan kontribusi yang positive dan negative terhadap kualitas hidup manusia.ASE sebagai suatu penerapan akuntansi di bidang ilmu social termasuk bidang sosiologi, politik ekonomi.

Ada juga yang memberikan istilah lain dari ASE yaitu Akuntansi Sosial yang terdiri dari Akuntansi Mikro Sosial dan Akuntansi Makro Sosial.

a. Faktor Penyebab munculnya ASE :

Kesadaran masyarakat akan perlunya dijaga kelestarian lingkungan untuk kelangsungan hidup manusia dan penekanan pada kelestarian hidup dan kesejahteraan sosial semakin tinggi menjadi pendorong munculnya ASE. 
b. Faktor pendorong munculnya ASE adalah:

- Adanya kesadaran dan komitmen terhadap kesejahteraan social tidak hanya mengejar pertumbuhan ekonomi.

- Adanya paradigma kesadaran lingkungan tidak seperti selama ini lingkungan diabdikan untuk perusahaan, untuk mengejar keuntungannya.

- Munculnya perspektif ecosystem, dimana system global tidak bisa berjalan sendiri sendiri tanpa memperhatikan system lain. Sistem ekonomi harus berjalan

- Munculnya perhatian terhadap perlindungan kepentingan social. Dengan gencarnya pertumbuhan ekonomi maka sering melupakan kepentingan social yang merugikan masyarakat, namun lama kelamaan muncul kesadaran akan pentinganya diperhatikan kepentingan social tidak hanya kepentingan ekonomi.

c. Perkembangan Akutansi Sosial Ekonomi

Pemikiran ASE dapat dirujuk ke Pasca Perang Dunia ke II dimana semakin dituntut kualitas hidup tidak saja pertumbuhan ekonomi.Tahun 1960an sudah muncul beberapa pengembangan indikator social, 
akutansi sosial, pengukuran kualitas hidup, monitoring perubahan social, dan pelaporan social.Pelaporan ASE ini sudah mulai diikuti dan menjadi lazim bagi beberapa perusahaan besar khususnya di Negara- Negara maju baik karena kebijakan untuk mengambil hati Publik atau secara sukarela maupun karena rekomendasi atau saransaran atau kewajiban dari regulator (SEC, BAPEPAM). Di Indonesia menunjukan bahwa perusahaan masih sangat rendah dalam melakukan pengungkapan aspek sosial.

\section{Akuntansi Islam}

Akutansi Islam atau Akutansi Syariah pada hakekatnya adalah penggunaan akutansi dalam menjalankan syariah Islam. Shahata (Harahap, 1997:272) misalnya mendefinisikan Akutansi Islam sebagai berikut:

"Postulat, standar, penjelasan dan prinsip akutansi yang menggambarkan semua hal...sehingga akutansi Islam secara teoritis memiliki konsep, prinsip, dan tujuan Islam juga. Semua ini secara serentak berjalan bersama bidang ekonomi, social, politik, idiologi, etika, kehidupan, keadilan dan hukum 
Islam. Akutansi dan bidang lain itu adalah satu paket dan tidak bisa dipisahkan satu sama lain,."

Sesuai dengan penjelasan Hayashi (1989) Akutansi dalam bahasa Arab disebut Muhasabah terdapat 48 kali disebut dalam Alquran. Kata Muhasabah memiliki 7 pengertian menurut Hayashi (1989):

a. Yahsaba yang berarti menghitung, to compute, atau mengukur atau to measure pencatatan dan perhitungan perbuatan seseorang secara terus menerus

b. Hasaba adalah selesaikan tanggung jawab

c. Tahasaba berarti menjaga

d. Mencoba mendapatk

e. Mengharapkan pahala diakhira

f. Menjadikan perhatian atau mempertanggungjawabkan

\section{Akuntansi Sosial Ekonomi Islam dalam Konteks Kekinian}

Akuntansi Islam dam konteks kekinian diartikan sebagai akuntansi dalam perspektif Islam yang mampu menjawab bagaimana seharusnya profil akuntansi Islam dalam situasi saat ini dimana system ekonomi, politik, ideology, hukum dan etika masih didominasi system lain yaitu system kapitalis yang dasar filosofinya berbeda bahkan 
bertolak belakang dengan system nilai Islam. Akutansi Islam terpaksa mengadopsi berbagai jargon kapitalis tetapi secara pelan pelan tapi pasti dikonversi dengan teknik dan prinsip nilai Islam sibisanya sesuai konteksnya.

Dalam konteks kekinian respons kita terhadap ASE adalah menerima dan mendorongnya untuk diterapkan sehingga pada suatu saat disadari keterbatasan akuntansi kapitalis ini dan pada akhirnya kita menerapkan Akuntansi Islam secara Kaffah atau secara menyeluruh dan terpadu.

\section{Menuju Perumusan kerangka Teori Akuntansi Islam}

Hanfiffa dan Hudaib (2000)mengemukakan bahwa kerangka konsep teori Akuntansi syariah itu terdiri dari beberapa level yang saling mempengaruhi:

1. Level I : Al-quran dan Hadist,qiyas, Ijtihad dan Ijma

2. Level II : Syariat Islam. Tujuan dari syariat ini adalah

a. Menciptakan keadilan sosial dan kebaikan,

b. Merealisir kebaikan kepada masyarakat baik di dunia maupun di akhirat (al-falah)

3. Level III : Etika dan Moralitas. Ini terdiri dari

: Iman, Taqwa, Kebaikan, Ibadah, Kewajiban, 
Ikhtiar, Hubungan dengan Allah, Hubungan dengan Manusia

4. Level IV : Bangunan Politik, Ekonomi dan Sosial

Politik berdasarkan musyawarah dan tanggung jawab

- Ekonomi yang halal, tanpa riba, menunaikan zakat

Sosial menekankan kepentingan publik dan amanah.

\section{Perbedaan Akuntansi Islam dan Akuntansi Konvensional}

Perbedaan dari segi pengertian, yaitu:

Akuntansi islam lebih mengarah pada pembukuan, pendataan, kerja dan usaha, kemudian juga perhitungan dan perdebatan (Tanya jawab) berdasarkan syarat-syarat yang telah disepakati dan selanjutnya penentuan imbalan atau balasan yang meliputi semua tindaktanduk danpekerjaan, baik yang berkaitan dengan keduniaan maupun yang berkaitan dengan keakhiratan.

Akuntansi konvensional ialah seputar pengumpulan dan pembukuan, penelitian tentang keteranganketerangan dari berbagai macam aktivitas. 


\section{Perbedaan dari segi tujuan, yaitu:}

Akuntansi islam bertujuan menjaga harta yang merupakan hujjah atau bukti ketika terjadi perselisihan, membantu mengarahkan kebijaksanaan, merinci hasilhasil usaha untuk perhitungan zakat, penentuan hak-hak mitra bisnis dan juga membantu menetapkan imbalan dan hukuman serta penilaian evaluasi kerja dan motivasi. Akuntansi konvensional menjelaskan utang piutang, untung rugi, sentral moneter dan membantu dalam mengambil ketetapan-ketetapan manajemen.

\section{Perbedaan dari segi karakteristik, yaitu:}

Akuntansi islam berdasarkan pada nilai-nilai akidah dan akhlak, maka sudah menjadi tugas seorang akuntan untuk memberikan data-data dalam membantu orang-orang yang bersangkutan tentang sejauh mana hubungan kesatuan ekonomi dengan kaidah-kaidah dan hukumhukum syariat islam dalam bidang muamalah.

Seorang akuntan muslim selalu sadar bahwa ia harus bertanggung jawab dihadapan Allah tentang pekerjaannya, dan ia tidak boleh menuruti keinginan pemilik modal (pemilik proyek) kalau ada langkah- 
langkah penyelewengan dari hukum Allah serta memutarbalikkan fakta (data yang akurat).

Akuntansi konvensional didasarkan pada ordonasi atau peraturan-peraturan dan teori-teori yang dibuat oleh manusia yang memiliki sifat khilaf, lupa, keterbatasan ilmu dan wawasan.Maka konsep itu labil dan tidak permanen.

Konsep, system, dan teknikakuntansi yang membantu suatu lembaga atau organisasi untuk menjaga agar tujuan fungsi dan operasionalnya berjalan sesuai dengan ketentuan syariah, dapat menjaga hak hal stakeholders yang ada didalamnya, dan mendorong menjadi lembaga yang dapat mencapai kesejahteraan hakiki dunia dan akhirat.

Menurut Husein Syahatah, dalam buku Pokok-Pokok Pikiran Akuntansi Islam, antara lain, terdapat pada halhal sebagai berikut:

a. Akuntansi konvensional :

- Konsep modal pokok (capital) belum ditentukan, sehingga cara menentukan nilai/harga untuk melindungi modal pokok sering berbeda pendapat 
- Modal terbagi 2, yakni modal tetap (aktiva tetap) dan modal yg beredar (aktiva lancar)

- Mempraktekkan teori pencadangan \& ketelitian dari menanggung semua kerugian dalam perhitungan

- Mengeyampingkan laba yg bersifat mungkin

- Menerapkan prinsip laba universal, mencakup laba dagang, modal pokok, transaksi, juga uang dari sumber yg haram

- Laba hanya ada ketika adanya jual beli

b. Akuntansi Islam :

- Konsep modal pokok dalam islam berdasarkan nilai tukar yang berlaku, dengan tujuan melindungi modal pokok dari segi kemampuan produksi di masa yg akan datang dlm ruang lingkup perusahaan yg kontinuitas

- Barang-barang pokok dibagi menjadi harta berupa uang (cash) dan harta berupa barang (stock), dst barang dibagi menjadi barang milik dan barang dagang

- Mata uang (emas, perak, dll) bukan tujuan segalanya, melainkan hanya sebagai perantara utk 
pengukuran \& penentuan nilai/harga (sebagai sumber harga/nilai)

- Penentuan nilai dan harga berdasarkan nilai tukar yg berlaku

- Membentuk cadangan untuk kemungkinan bahaya dan resiko

- Membedakan laba dari aktivitas pokok dan laba yg berasal dari capital/modal pokok dengan yang berasal dari transaksi dan wajib menjelaskan pendapatan dari sumber yang haram jika ada, serta berusaha menghindari \& menyalurkan pada tempat-tempat yg th ditentukan oleh para ulama fiqh

- Laba dari sumber yang haram tidak boleh dibagi untuk mitra usaha/dicampurkan pada pokok modal

- Laba akan ada ketika adanya perkembangan dan pertambahan pada nilai barang, baik yg telah terjual/belum. Akan tetapi jual beli adalah suatu keharusan utk menyatakan laba, dan laba tidak boleh dibagi sebelum nyata laba itu diperoleh.

Dengan demikian, dapat diketahui, bahwa perbedaan antara sistem Akuntansi Syariah Islam dengan 
Akuntansi Konvensional adalah menyentuh soal-soal inti dan pokok, sedangkan segi persamaannya hanya bersifat aksiomatis.

\section{c. Riset Akuntansi Islam}

Riset Akuntansi adalah upaya yang dilakukan untuk mencari kebenaran di bidang akuntansi.Hasil dari riset akuntansi ini merupakan penyambung antara fenomena sosial di bidang akuntansi dengan struktur teori akuntansi.Dimana fenomena sosial tersebut dituangkan dalam berbagai bentuk "statement ilmiah" sehingga menjadi teori.

Metode-metode yang digunakan dalam riset akuntansi islam, yaitu :

1. Metode Kuantitatif

Yaitu metode yang menggunakan rumus-rumus statistik dalam mengidentifikasi dan mengolah variabel yang muncul dari suatu problem atau masalah yang akan dijawab.

2. Metode Kualitatif 
Yaitu menggunakan narasi dan penguraian tentang variabel yang akan dibahas tanpa harus melakukan pengukuran terlebih dahulu.

3. Metode Campuran antara Kuantitatif dan Kualitatif Metode ini menggambungkan dari dua metode diatas, yaitu sebagian menggunakan metode kualitatif dan sebagian lagi menggunakan metode kuantitatif

\section{EVALUASI}

Jawab dan Jelaskan pertanyaan diawah ini

1. Uraikan prinsip akuntansi Islam yang Anda Pahami.

2. Jelaskan perkembangan teori akuntansi islam

3. Ide atau gagasan penelitian apa yang Anda lakukan untuk mengembangan akuntasi Islam?Jelaskan. 


\section{BAGIAN 4 \\ KONSEP TRANSAKSI SYARIAH}

\section{Tujuan Instruksional Umum}

Mahasiswa mampu :

1. Secara umum mengetahui jenis transaksi-transaksi dasar Syariah

2. Mengetahui jenis akad transaksi syariah

3. Menjelaskan konsep transaksi Syariah

4. Menjelaskan jenis transaksi dasar syariah

5. Menjelaskan jenis akad transaksi syariah

\section{SUB POKOK BAHASAN}

\section{Akad Tabarru'}

Akad Tabarru' adalah perjanjian yang merupakan transaksi yang tidak ditujukan untuk memperoleh laba (transaksi nirlaba). Tujuan dari akad ini adalah tolong menolong dalam rangka berbuat kebaika. Dalam Akad Tabarru' pihak yang berbuat kebaikan tidak berhak mensyaratkan imbalan apapun kepada pihak lainnya karena ia hanya mengharapkan imbalan dari Allah SWT. Namun, tidak mengapa jika pihak yang berbuat 
kebaikan meminta sekedar menutupi biaya yang ditanggungnya untuk melakukan akad tabarru' tersebut, sepanjang tidak mengambil laba dari akad tersebut.

Ada 3 bentuk akad Tabarru', yaitu :

1. Meminjamkan Uang

Meminjamkan uang termasuk akad Tabarru' karena tidak boleh melebihkan pembayaran atas pinjaman yang diberikan, karena setiap kelebihan tanpa 'iwad adalah riba. Ada 3 jenis pinjaman, yaitu :

a. Qardh merupakan pinjaman yang diberikan tanpa mensyaratkan apapun, selain mengembalikan pinjaman tersebut setelah jangka waktu tertentu.

b. Rahn merupakan pinjaman yang mensyaratkan suatu jaminan dalam bentuk atau jumlah tertentu

c. Hiwalah adalah bentuk pinjaman dengan cara mengambil alih piutang dari pihak lain. 
2. Meminjamkan Jasa

Meminjamkan Jasa berupa keahlian atau keterampilan termasuk akad Tabarru'. Ada 3 jenis pinjaman jasa, yaitu :

a. Wakalah adalah memberikan pinjaman berupa kemampuan kita saat ini untuk melakukan sesuatu atas nama orang lain

b. Wadi'ah adalah bentuk turunan akad wakalah, dimana pada akad ini telah dirinci tentang jenis penitipan dan pemeliharaan. Sehingga selama pemberian jasa tersebut kita juga bertindak sebagai wakil dari pemilik barang.

c. Kafalah merupakan bentuk turunan akad wakalah, dimana pada akad ini terjadi atas wakalah bersyarat.

3. Memberikan sesuatu

Dalam akad ini, pelaku memberikan sesuatu kepada orang lain. Ada 3 bentuk akad ini, yaitu :

a. Waqaf merupakan pemberian dan penggunaan pemberian yang dilakukan untuk kepentingan umum dan agama, serta pemberian itu tidak dapat dipindahtangankan 
b. Hibah, shadaqah merupakan pemberian sesuatu secara sukarela kepada orang lain.

\section{Akad Ijarah}

Akad ijarah merupakan akad yang memfasilitasi transaksi pemindahan hak guna (maanfaat) atas suatu barang atau jasa dalam waktu tertentu melalui pembayaran sewa/upah tanpa diikuti pemindahan kepemilikan barang.

Bagi bank syariah, transaksi ini memiliki beberapa keunggulan jika dibandingkan dengan jenis akad lainnya yaitu:

1. Dibandingkan dengan akad murabahah, akad ijarah lebih fleksibel dalam hal objek transaksi.

2. Dibandingkan dengan investasi, akad ijarah mengandung resiko usaha yang lebih rendah, yaitu adanya pendapatan sewa yang relatif tetap.

Dari segi objeknya, akad ijarah dibagi para ulama fiqih kepada dua macam :

1. Ijarah yang bersifat manfaat (sewa). Ijarah yang bersifat manfaat umpamanya adalah sewa menyewa rumah, toko, dan kendaraan. 
2. Ijarah yang bersifat pekerjaan (jasa). Ijarah yang bersifat pekerjaan ialah memperkerjakan seseorang untuk melakukan suatu pekerjaan. Ijarah 'ala al'amal (upah mengupah) terbagi menjadi dua, yaitu :

1. Ijarah khusus yaitu ijarah yang dilakukan oleh seorang pekerja. Hukumnya orang yang bekerja tidak boleh bekerja selain dengan orang yang memberinya upah, seperti pembantu rumah tangga.

2. Ijarah Musytarak adalah ijarah yang dilakukan secara bersama-sama atau melalui kerjasama. Hukumnya diperbolehkan bekerjasama dengan orang lain. Contohnya para pekerja pabrik

Skema Ijarah

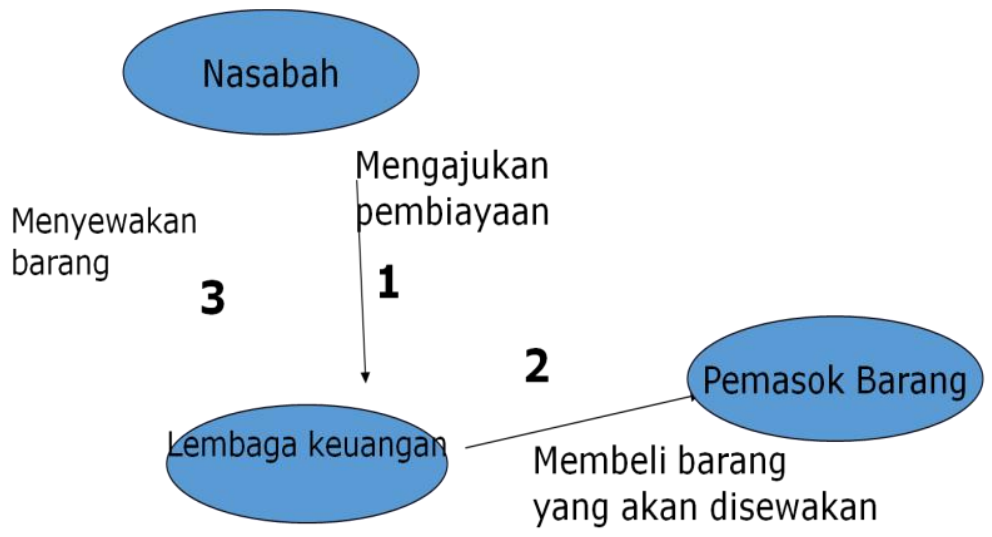




\section{Natural Certainly Contrac}

Natural Certainty Contrac adalah kontrak/akad dalam bisnis yang memberikan kepastian pembayaran, baik dari segi jumlah maupun waktunya. Cash flownya bisa diprediksi dengan relatif pasti, karena sudah disepakati oleh kedua belah pihak yang bertanksaksi di awal akad. Kontrak-kontrak ini secara menawarkan return yang tetap dan pasti. Objek pertukarannya (baik barang maupun jasa) pun harus ditetapkan di awal akad dengan pasti, baik jumlahnya, mutunya, harganya, dan waktu penyerahannya.

Macam-macam Natural Certainly Contrac sebagai berikut :

1. akad jual beli

a. Bai' naqdan adalah jual beli biasa yang dilakukan secara tunai. Dalam jual beli ini bahwa baik uang maupun barang diserahkan di muka pada saat yang bersamaan, yakni di awal transaksi (tunai)

b. Bai' muajjal adalah jual beli dengan cara cicilan. Pada jenis ini barang diserahkan di awal periode, sedangkan uang dapat diserahkan pada periode selanjutnya. 
c. Murabahah adalah jual beli dimana besarnya keuntungan secara terbuka dapat diketahui oleh penjual dan pembeli.

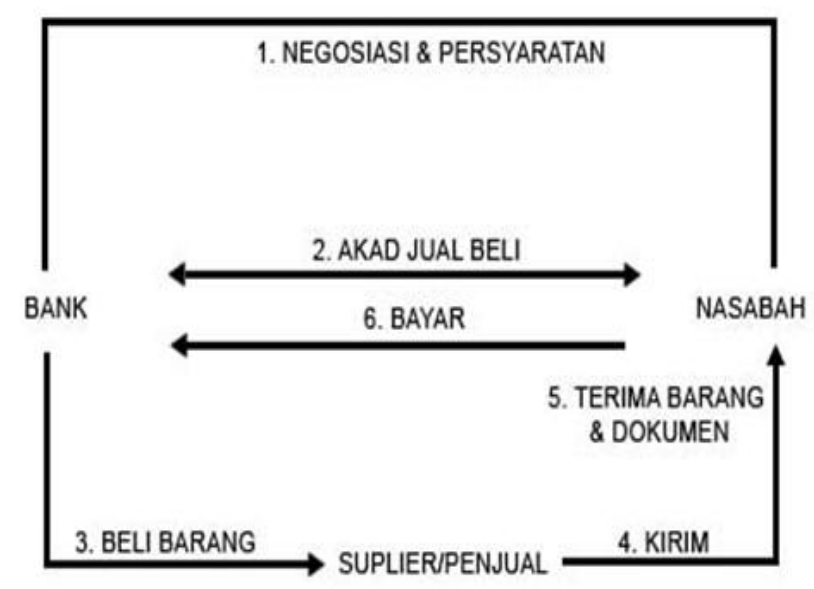

d. Salam adalah akad jual beli barang dengan cara pemesanan dan pembayaran harga lebih dahulu dengan syarat-syarat tertentu. 


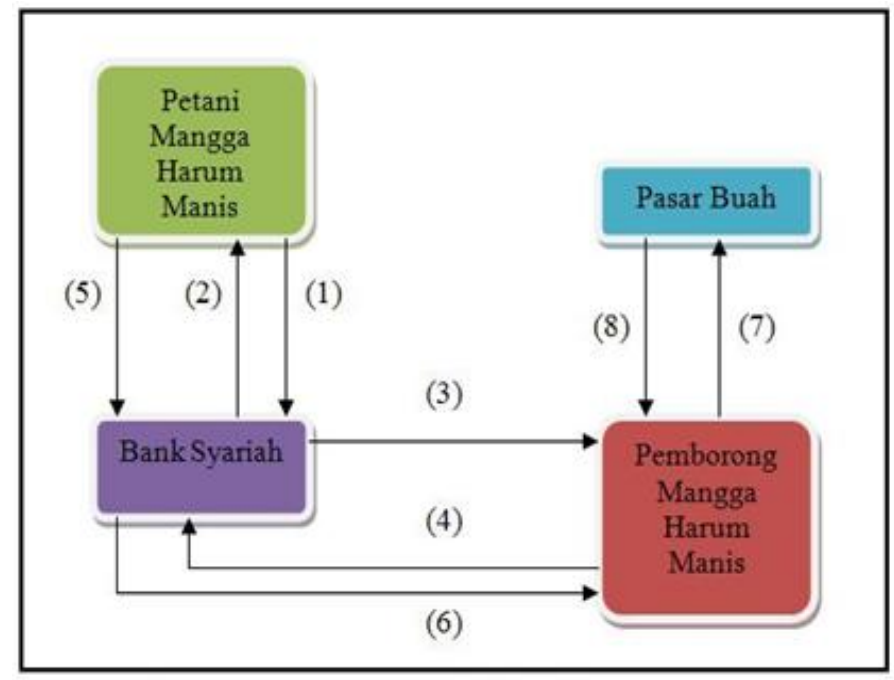

e. Istishna adalah akad jual beli dalam bentuk pemesanan pebuatan barang tertentu dengan kriteria dan persyaratan tertenu yang disepakati antara pemesan dan penjual.

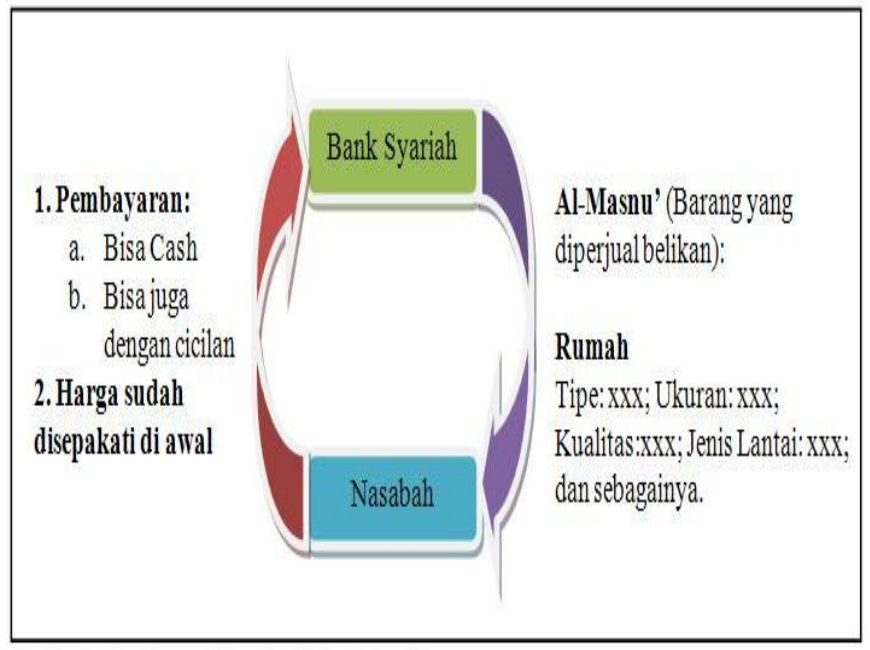




\section{f. Akad Sewa Menyewa}

a. Ijarah adalah akad pemindahan hak guna atas suatu barang atau jasa dalam waktu tertentu melalui pembayaran sewa/upah tanpa diikuti dengan pemindahan kepemilikan barang itu sendiri

b. Ijarah Muntahiya Bittamlik (IMBT) adalah ijarah yang membuka kemungkinan perpindahan kepemilikan atas objek ijarahnya pada akhir periode

c. Ju'alah adalah akad ijarah yang pembayarannya didasarkan kepada kinerja objek yang disewa/diupah

Gambar ijarah

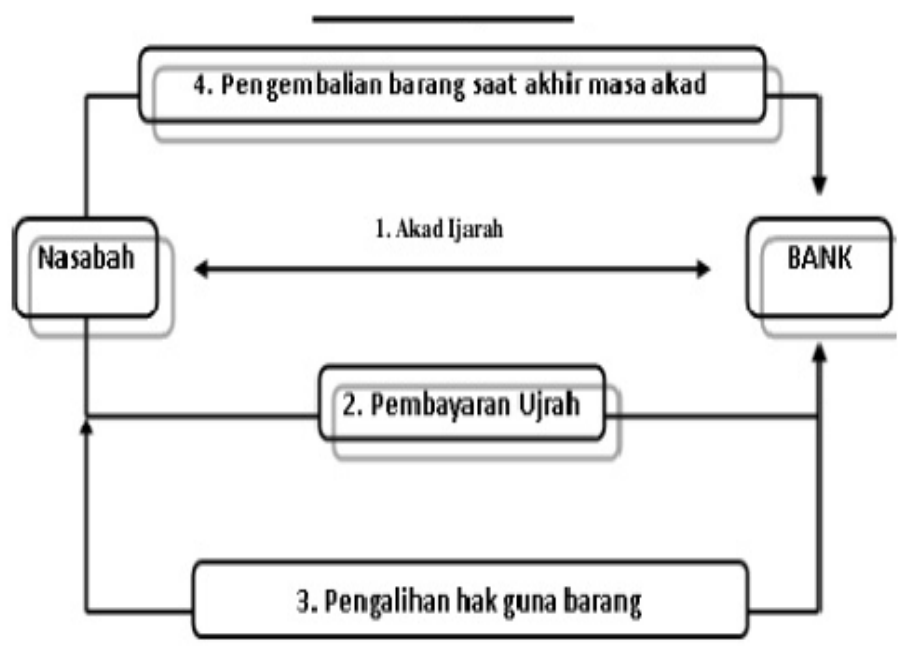




\section{Natural Uncertainly Contrac}

Natural Uncertainly Contrac adalah kontrak/akad dalam bisnis yang tidak memberikan kepastian pendapatan, baik dari segi jumlah maupun waktunya.

Dalam NUC, pihak-pihak yang bertransaksi saling mencampurkan asetnya menjadi satu kesatuan, dan kemudian menanggung resiko bersama-sama untuk mendapatkan keuntungan. Macam-macam Natural Uncertainly Contrac adalah sebagai berikut :

1. Musyarakah

Menurut Syafi'i Antonio, Akad Musyarakah adalah akad kerjasama antara dua pihak atau lebih untuk suatu usaha tertentu dimana masing-masing pihak memberikan kontribusi dana dengan kesepakatan bahwa keuntungan dan risiko akan ditanggung bersama sesuai kesepakatan.

Macam-macam musyarakah :

a. mufawadhah

akad kerjasama dimana masing-masing pihak memberikan porsi dana yang sama.

b. inan

akad kerjasama dimana pihak yang bekerjasama memberikan porsi dana yang 
tidak sama jumlahnya. Keuntungan dibagi sesuai dengan kesepakatan dan kerugian ditanggung sebesar porsi modal

c. wujuh

akad kerjasama dimana satu pihak memberikan porsi dana dan pihak lainnya memberikan porsi berupa reputasi. Keuntungan dibagi sesuai dengan kesepakatan dan kerugian ditanggung sesuai dengan porsi modal, pihka yang memberikan dana akan mengalami kerugian kehilangan dana dan pihak yang memberikan reputasi akan mengalami kerugian secara reputasi

d. abdan

akad kerjasama dimana pihak-pihak yang bekerja bersama-sama menggabungkan keahlian yang dimilikinya. Keuntungan dibagi berdasarkan kesepakatan dan kerugian ditanggung bersama. 


\section{Skema Musyarakah:}

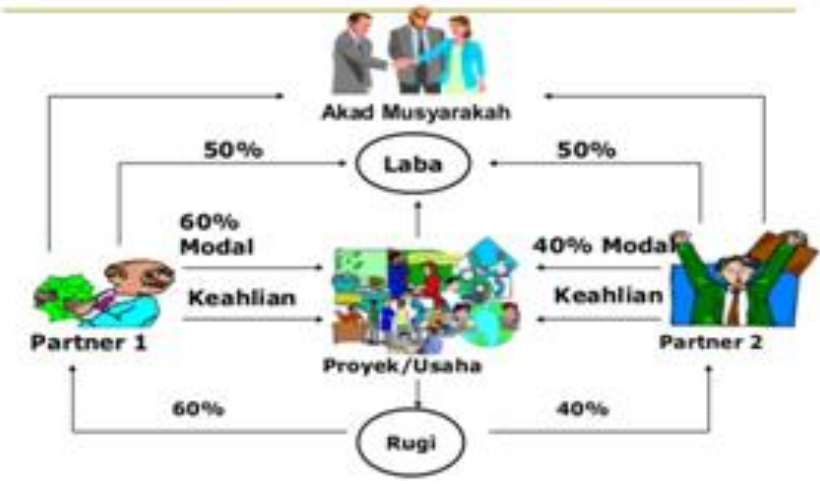

e. mudharabah

akad kerjasama dimana satu pihak menginvestasikan dana sebesar 100 persen dan pihak lainnya memberikan porsi keahlian.

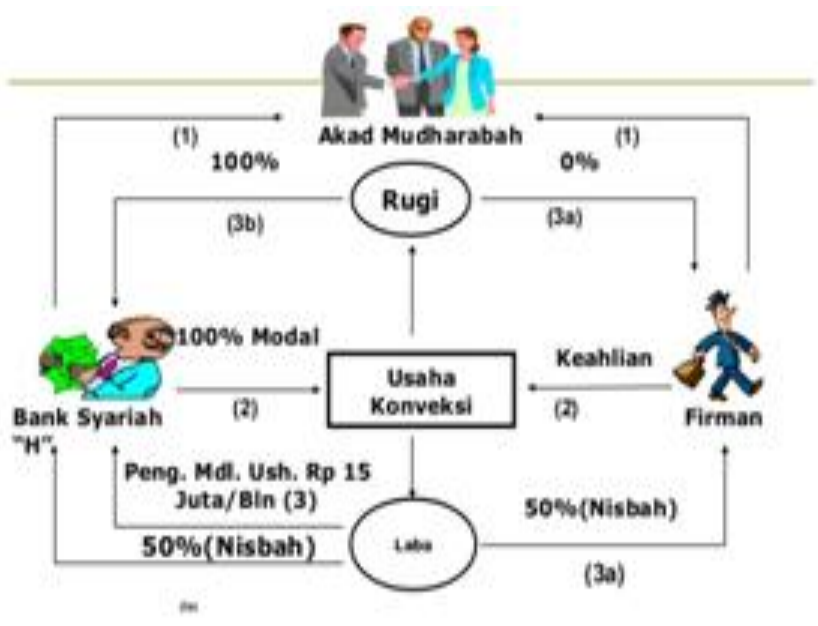




\section{Wa'at dan Akad}

Akad dan Wa'ad dalam konteks fiqih muamalah merupakan hal yang berbeda meskipun keduanya hampir sama yang merupakan bentuk perjanjian. Akad merupakan suatu kesepakatan bersama antara kedua belah pihak atau lebih baik secara lisan, isyarat, maupun tulisan yang memiliki implikasi hukum yang mengikat untuk melaksanakannya. Sedangkan Wa'ad adalah janji antara satu pihak kepada pihak lainnya, pihak yang diberi janji tidak memikul kewajiban apaapa terhadap pihak lainnya. Dalam Wa'ad bentuk dan kondisinya belum ditetapkan secara rinci dan spesifik. Bila pihak yang berjanji tidak dapat memenuhi janjinya, maka sanksi yang diterimanya lebih merupakan sanksi moral.

\section{EVALUASI}

1. Sebutkan macam-macam akad dalam transaksi syariah?

2. Gambarkan skema transaksinya!

3. Apa perbedaan antra salam, murabahah dan Istishna? Jelaskan! 


\section{BAGIAN 5 \\ KERANGKA DASAR PENYUSUNAN DAN \\ PENYAJIAN LAPORAN KEUANGAN BANK \\ SYARIAH}

\section{Tujuan Instruksional Umum :}

1. Memahami konsep dasar tentang Akuntansi Perbankan Syariah

2. Menjelaskan siklus Akuntansi Perbankan Syariah

3. Memahami asumsi-asumsi dasar, pengakuan akuntansi dan kensep pengukuran dalam Akuntansi Perbankan Syariah

4. Membuat Laporan Akuntansi Perbankan Syariah

5. Menjelaskan perkembangan Akuntansi Perbankan SYariah

6. Menjelaskan tujuan Akuntansi Bank Syariah

7. Menjelaskan tujuan Laporan Keuangan Bank Syariah

8. Menggambarkan dan Menjelaskan siklus akuntansi Bank Syariah

9. Menjelaskan asumsi-asumsi dasar yang digunakan dalam Akuntansi Perbankan Syariah

10. Menjelaskan konsep pengukuran dan pengakuan akuntansi Bank Syariah

11. Membuat persamaan Akuntansi Perbankan Syariah

12. Menyajikan Laporan Keuangan Perbankan Syariah 


\section{SUB POKOK BAHASAN}

\section{Pengantar Akuntansi Bank Syariah}

Secara umum bank adalah bertemunya pihak yang surplus dana dengan pihak yang deficit dana yang usaha pokoknya adalah menghimpun dana dan menyalurkan kembali dana tersebut ke masyarakat dalam bentuk kredit serta memberikan jasa - jasa dalam lalu lintas pembayaran dan peredaran uang (Kuncoro, 2002).

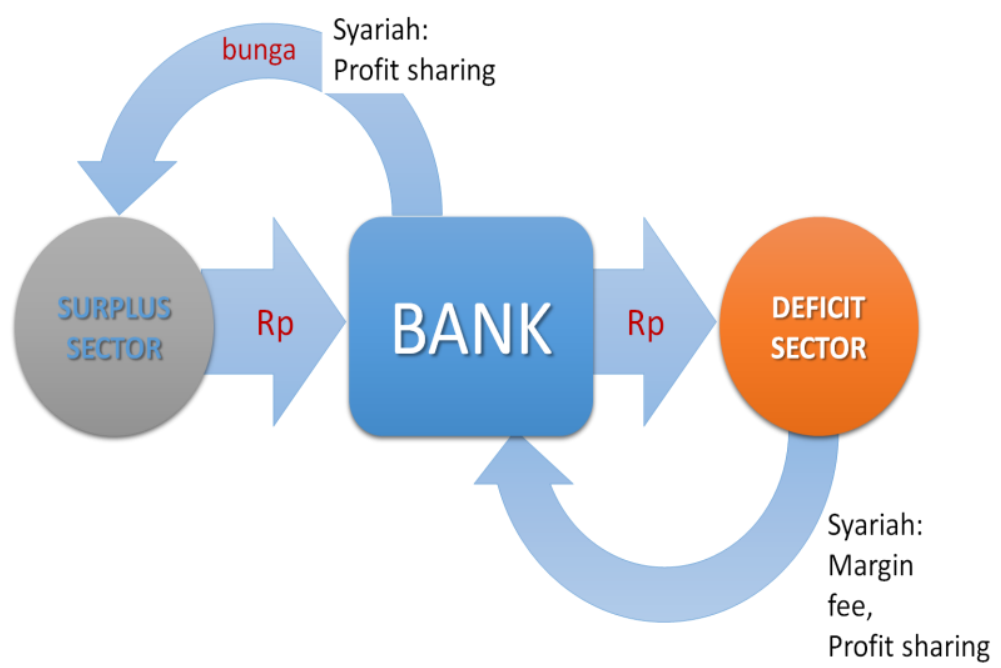

Menurut UU No. 10 tahun 1998 tentang Perbankan Syariah disebutkan bahwa Bank Syariah adalah bank yang 
menjalankan kegiatan usahanya berdasarkan prinsip syariah dan menurut jenisnya terdiri atas bank umum syariah dan bank pembiayaan rakyat syariah. Berikut penjelasan menyangkut Pengertian atau Definisi Bank Syariah menurut para ahli:

- Sudarsono (2004), mendefinisikan Bank Syariah sebagai suatu lembaga keuangan yang usaha pokoknya memberikan kredit dan jasa jasa lain dalam lalu lintas pembayaran serta peredaran uang yang beroperasi dengan prinsip prinsip syariah.

- Siamat, Dahlan (2004), menguraikan pengertian Bank Syariah merupakan bank yang dalam menjalankan usahanya berdasarkan prinsip-prinsip hukum atau syariah dengan selalu mengacu pada Al-Quran dan Al-Hadist

- Schaik (2001), Bank Islam atau Bank Syariah merupakan bentuk dari bank modern yang berdasarkan pada hukum Islam yang sah, dikembangkan pada abad pertama Islam, bank ini menggunakan konsep berbagi resiko sebagai suatu metode utama dan meniadakan sistem keuangan 
berdasarkan kepastian atau keuntungan yang telah di tentukan sebelumnya.

- Muh. Syafe'i Antonio dan Perwataatmadja (1992) membagi pengertian terkait hal ini dalam 2 pengertian : Pertama, Bank Islam adalah bank yang beroperasi berdasarkan prinsip-prinsip syari'ah Islam. Kedua, Bank Islam adalah bank yang tata cara beroperasinya mengacu kepada ketentuan Al-Qur'an dan Hadits. Dari penjelasan kedua definisi ini, disimpulkan bahwa bank syariah merupakan bank yang beroperasi berdasarkan pada prinsip-prinsip syariah, yakni tata cara beroperasinya mengacu pada aturan Al-Quran dan Hadits.

Ciri-ciri umum Bank Syariah adalah sebagai berikut :

- Beban biaya yang telah disepakati pada waktu melakukan akad perjanjian diwujudkan dalam bentuk jumlah nominal yang besarnya fleksibel atau tidaklah kaku dan dapat ditawar dalam batas-batas yang masih wajar.

- Pengarahan dana masyarakat dalam bentuk deposito atau tabungan oleh penyimpan dianggap sebagai titipan (al-wadi'ah) sedangkan bagi bank dianggap 
sebagai titipan yang diamanatkan sebagai pernyataan dana pada proyek yang dibiayai oleh bank sesuai dengan prinsip-prinsip syariah sehingga bagi penyimpan tidaklah dijanjikan imbalan yang pasti (fixed return).

- Penggunaan persentase dalam hal kewajiban untuk melakukan pembayaran harus selalu dihindarkan. Karena persentase bersifat melekat pada sisa hutang meskipun utang hingga batas waktu perjanjian telah jatuh tempo atau berakhir.

- Didalam kontrak pembiayaan proyek bank tidak menetapkan perhitungan berdasarkan keuntungan yang pasti (Fixed Return) yang ditetapkan dimuka. Bank Syariah menerapkan sistem berdasarkan atas modal untuk jenis kontrak al mudharabah dan al musyarakah dengan system bagi hasil (Profit and losery) yang tergantung pada besarnya keuntungan.

- Bank Syari'ah tidak menerapkan jual beli atau sewamenyewa uang dari mata uang yang sama dan transaksinya itu dapat menghasilkan keuntungan. Jadi mata uang itu dalam memberikan pinjaman pada umumnya tidak dalam bentuk tunai melainkan dalam 
bentuk pembiayaan pengadaan barang selama pembiayaan, barang tersebut milik bank.

- Adanya dewan Syari'ah yang bertugas mengawasi bank dari sudut Syariah. Bank Syariah selalu menggunakan istilah-istilah dari bahasa arab dimana istilah tersebut tercantum dalam fiqih Islam

- Adanya produk khusus yaitu pembiayaan tanpa suatu beban murni yang bersifat sosial, dimana nasabah tidaklah berkewajiban untuk mengembalikan pembiayaan (al-qordul hasal)

- Fungsi lembaga bank juga mempunyai fungsi amanah, artinya berkewajiban menjaga dan ikut bertanggung jawab atas keamanan dana yang sudah dititipkan dan memiliki kesiapan sewaktu-waktu apabila dana ditarik kembali sesuai dengan perjanjian.

Akuntansi syariah merupakan bagian dari Akuntansi yang relatif sangat baru sehingga tidak banyak negara yang melakukan pembahasan akuntansi syariah. Pada tahun 1993 Dewan Bahasa dan Pustaka Kementerian Pendidikan Malaysia, Kualalumpur mengeluarkan buku yang diberi nama "Sistem Perakaunan Dalam Islam" yang membahas antara lain tentang harta, kaedah 
perakaunan Islam, unsur-unsur perbelanjaan dan pendapatan dalam Islam, Perakaunan Bank Islam. Perakaunan Harta Pustakan dam waris dalam Islam dan sebagainya. pengantar akuntansi bank syariah

Pada tanggal 1 Safar, $1410 \mathrm{H}$ bertepatan dengan tanggal 27 Maret, 1991 di Negara Bahrain, berdiri Accounting and Auditing Organization for Islamic Financial Institutions, suatu badan usaha nirlaba yang otonom. Pada tahun 1998 mengeluarkan buku tentang Akuntansi syariah yang diberi judul "Accounting and Auditing Standard for Islamic Financial Institutions" (AAOIFI) yang dapat dipergunakan sebagai acuan dalam pembahasan akuntansi syariah, yang hanya membahas tentang accounting dan Auditing.Pada tahun 1999 buku tersebut dirubah namanya menjadi "Accounting, Auditing and Governance Standard for Islamic Financial Institutions" yang membahas Accounting, Auditing dan Governance serta terdapat perubahan cakupan organisasi tersebut. pengantar akuntansi bank syariah

Organisasi tersebut mempunyai peranan yang cukup besar, karena adanya para pakar yang terlibat dalam pembahasan tersebut. Pada Buku Accounting, Auditing and Governance Standard for Islamic Financial 
Institutions, tahun 1999 disebutkan organisasi dan ruang lingkup tanggung jawab Accounting and Auditing Organization for Islamic Financial Institutions adalah sebagai berikut: pengantar akuntansi bank syariah

1. Majelis Umum, merupakan pihak (anggota pendiri dan anggota bukan pendiri) yang berwenang tertinggi dan bertemu paling lama sekali dalam setahun. pengantar akuntansi bank syariah

2. Dewan Pengurus, yang terdiri 15 anggota yang diangkat oleh Majelis Umum, yang mewakili berbagai kategori yaitu badan pengatur dan pengawas, lembaga-lembaga keuangan Islam, dewan pengawas Syari'ah, profesor universitas, organisasi dan asosiasi yang bertanggung jawab untuk mengatur profesi akuntansi dan / atau bertanggung jawab untuk membuat standard akuntansi dan auditing, akuntan resmi (certified accountant), dan para pemakai lembaga keuangan lembaga-lembaga keuangan Islam. pengantar akuntansi bank syariah

3. Badan Standard Akuntansi dan Auditing, yang terdiri dari 15 anggota yang diangkat Dewan Pengurus, yang mencerminkan berbagai kategori yaitu badan pengatur dan pengawas, lembaga-lembaga keuangan 
Islam, dewan pengawas Syari'ah, profesor universitas, organisasi dan asosiasi yang bertanggung jawab untuk membuat standard akuntansi dan auditing, akuntan resmi, dan para pemakai laporan dari lembaga keuangan Islam. pengantar akuntansi bank syariah

4. Dewan Syari'ah, yang terdiri 4 anggota yang diangkat oleh Dewan Pengurus, yang mempunyai wewenang untuk memeriksa laporan akuntansi dan auditing yang diusulkan, standard praktek dan pedoman praktek dari sudut pandang Syari'ah dan juga untuk memeriksa setiap pertanyaan yang diterima oleh AAOIFI yang berhubungan dengan masalah-masalah Syari' ah. pengantar akuntansi bank syariah

5. Komite Eksekutif, anggota yang mempunyai kekuasaan untuk memeriksa rencana jangka pendek dan jangka panjang yang dibuat oleh Badan Standard, anggaran tahunan AAOIFI, peraturan-peraturan yang mengatur pembentukan komite dan gugus tugas, dan penunjukan konsultan. pengantar akuntansi bank syariah

6. Sekretariat Umum, yang mengkoordinasikan kegiatan kegiatan badan-badan berikut ini dan bertindak 
sebagai rapporteur dari Majelis Umum, Dewan Pengurus, Badan Standard, Komite Eksekutif, Dewan Syari'ah dan sub komite. Dia menjalankan urusan dan kegiatan sehari-hari dan juga mengkoordinasikan dan mengawasi studi yang berkaitan dengan pembuatan laporan, standard dan pedoman akuntansi dan auditing. Tanggung jawab dari Sekretaris Umum juga mencakup menguatkan hubungan AAOIFI dan organisasi organisasi lain dan mewakili AAOIFI pada konprensi, seminar dan pertemuan-pertemuan ilmiah.

Akuntansi di dalam Islam antara lain berhubungan dengan pengakuan, pengukuran dan pencatatan transaksi dan pengungkapan hak-hak dan kewajibankewajibannya secara adil. Allah berfirman: " Hai, orangorang yang beriman, apabila kamu bermu'amalah tidak secara tunai untuk waktu yang ditentukan, hendaklah kamu menuliskannya. Dan hendaklah seorang penulis diantara kamu menuliskannya dengan benar" (Surah 2 ayat 282). 
Allah juga berfirman: “ Wahai orang-orang yang beriman, jadilah kamu orang yang benar-benar penegak keadilan (kutipan dari Surah 4: ayat 135)".

Allah juga berfirman: "Kecelakaan besarlah bagi orangorang (yaitu) orang-orang yang apabila menerima takaran dari orang lain mereka minta dipenuhi, dan apabila mereka menakar atau menimbang untuk orang lain, mereka mengurangi, (Surah 83: ayat 1-3)". Allah juga berfirman di dalam hadist yang suci "Hai, hambaKu, Aku telah haramkan bagiku kezaliman dan telah mengharamkannya diantara kamu, jadilah janganlah saling menindas satu sama lain". Tidak diragukan bahwa berkurang atau berlebihnya dari hakhak dan kewajiban adalah tidak adil dan tidak bisa diterima di dalam Islam.Allah telah menyatakan bahwa seorang Muslim harus adil dan jujur di dalam urusanurusannya". Dia berfirman: "Sesungguhnya Allah menyuruh (kamu) berlaku adil dan berbuat kebajikan (kutipan dari Surah 16: ayat 90).

Akuntansi keuangan di dalam Islam harus memfokuskan pada pelaporan yang jujur mengenai posisi keuangan entitas dan hasil-hasil operasinya, dengan cara 
yang akan mengungkapkan apa yang halal dan apa yang haram. Ini sesuai dengan perintah Allah untuk bertolongtolongan di dalam mengerjakan kebaikan. Allah berfirman: “ Dan tolong menolonglah kamu dalam (mengerjakan) kebajikan dan takwa, dan janganlah tolong-menolong dalam berbuat dosa dan pelanggaran" (kutipan dari Surah 5: ayat 2). Ini berarti bahwa akuntansi keuangan di dalam Islam mempunyai sasaransasaran yang harus disadari dan dipatuhi oleh akuntan keuangan di dalam Islam.Dia tidak boleh memasuki bidang ini tanpa kesadaran dan pemahaman yang jelas mengenai sasaran akuntansi keuangan. Ini sesuai dengan firman Allah: "Dan hendaklah seorang penulis diantara kamu menuliskannya dengan benar" (kutipan dari Surah 2 ayat 282$)$.

Khalifah Umar Bin al-Khattab (radhiallahu 'anhu) meminta kepada para pedagang di pasar untuk mengetahui halal dan haram.Dia mengatakan "Tidak seorangpun yang diperbolehkan berjualan di pasar kami kecuali dia mempunyaipengetahuan agama, jika tidak mau tidak dia akan melakukan transaksi yang ribawi".Sehingga, oleh karena itu orang-orang yang bertugas harus menetapkan bagi akuntansi keuangan 
aturan-aturan yang diperlukan yang melindungi hak-hak dan kewajiban perorangan, dan menjamin pengungkapan yang memadai. pengantar akuntansi bank syariah

Perkembangan Akuntansi Bank Syariah secara konkrit baru dikembangkan pada tahun 1999, Bank Indonesia sebagai pemprakarsa, membentuk tim penyusunan PSAK Bank Syariah, yang tertuang dalam Surat Keputusan Gubernur Bank Indonesia Nomor 1/16/KEP/DGB/1999, yang meliputi unsur-unsur komponen dari Bank Indonesia, Ikatan Akuntan Indonesia, Bank Muamalat Indonesia dan Departemen Keuangan, hal ini seiring dengan pesatnya perkembangan Perbankan syariah yang merupakan implementasi dari Undang-Undang nomor 10 tahun 1998.

Dalam pembahasan terdapat cakupan yang jelas tanggung jawab antara Ikatan Akuntan Indonesia (Dewan Standar Akuntansi) dan Dewan Syariah Nasional, tetapi kedua unit tersebut tidak bisa dipisahkan satu dengan yang lain dalam melakukan pembahasan Akuntansi Perbankan Syariah. Ikatan Akuntan Indonesia bertanggung jawab terhadap pengukuran, pengakuan dan penyajian atau hal-hal lain yang berkaitan dengan 
akuntansi, dengan memperhatikan fakwa dari Dewan Syariah Nasional, karena unit ini yang berkompeten terhadap hal ini sedangkan Dewan Syariah Nasional bertanggung jawab terhadap syariah yang ada pada pembahasan akuntansi tersebut, karena unit ini yang berkompeten tentang syariah, dan berkaitan dengan akuntansi diserahkan kepada Dewan Standard Akuntansi.

Tim Penyusun PSAK telah membuahkan hasil sebagaimana telah diterbitkannya Exposure Draft Kerangka Dasar Penyusunan Laporan Keuangan Perbankan Syariah dan Exposure Draft tentang PSAK Perbankan Syariah pada bulan Maret 2000. Dari hasil exposure draft tersebut juga menghasilkan masukanmasukan yang sangat berarti, yang menuntut tim untuk mencermati lebih hati-hati, khususnya yang berkaitan dengan aspek syariah. Diskusi, pertemuan dengan dewan syariah nasional secara terus-menerus dilakukan, termasuk permintaan Dewan Standar Ikatan Akuntansi Indonesia kepada Dewan Syariah Nasional untuk mereview hasil akhir draft PSAK Perbankan Syariah, yang pada akhirnya keluar opini dari Dewan Syariah Nasional yang menyebutkan PSAK Bank Syariah tersebut secara umum tidak bertentanggan dengan aspek 
syariah, sehingga Ikatan Akuntansi Indonesia menerbitkan PSAK tentang akuntansi Perbankan Syariah yang diberi nomor 59 dengan judul Akuntansi Perbankan Syariah. pengantar akuntansi bank syariah.

Bank syariah sampai dengan tahun buku 2002 mengeluarkan laporan keuangan tahunannya belum ada keseragaman dan masih mengacu pada PSAK yang berlaku umum, khususnya PSAK 31 tentang Akuntansi Perbankan sepanjang tidak bertentangan dengan syariah karena PSAK 59 tentang Akuntansi Perbankan Syariah baru mulai berlaku untuk tahun buku 2003. Dalam memahami Akuntansi Perbankan Syariah, ada dua hal yang perlu diperhatikan yaitu pertama tentang Kerangka Dasar Penyusunan dan Penyajian Laporan Keuangan Perbankan Syariah yang memuat tentang Karakteristik Bank Syariah, Pemakai kebutuhan informasi, Tujuan akutansi keuangan, tujuan laporan keuangan, asumsi dasar, kedua tentang PSAK 59 yang memuat / mengatur tentang pengakuan, pengukuran, pengungkapan dan penyajian tentang produk, mudharabah, musyarakah, murabahah, istishna dan istishna paralel, salam dan salam paralel, Ijarah dan ijarah muntahiyah bittamlik, wadiah, qardh, sharf dan kegiatan berbasis imbalan. 
Dalam PSAK nomor 59 tentang Akuntansi Perbankan Syariah hanya membahas tentang ketentuan-ketentuan pokok saja dan sebagai upaya untuk mendukung serta melengkapi PSAK Perbankan Syariah tersebut telah dibentuk juga tim penyusun Pedoman Akuntansi Perbankan Syariah Indonesia (PAPSI) yang memuat pedoman secara rinci dan ilustrasi transaksi dari PSAK Perbankan Syariah tersebut.

Sudah sepatutnya penerbitan PSAK 59 tentang Akuntansi Perbankan Syariah ini merupakan suatu kebanggaan bahwa Bank Syariah telah mempunyai acuan untuk melakukan pembukuan transaksinya, terlepas masalah Akuntansi Islam yang selama ini secara akademis masih diperdebatkan, karena hal ini membuktikan bahwa Akuntansi Indonesia adalah kumpulan profesi yang pertama kali mengeluarkan standard yang harus diikuti oleh profesi tersebut. Sangat disadari bahwa dalam Kerangka Dasar tersebut tidak sempurna dan tidak dilakukan pembahasan secara rinci, oleh karena itu kerangka dasar dalam akuntansi umum pun masih berlaku sepanjang tidak bertentangan dengan prinsip syariah, hal ini dikarenakan keterbatasan pemahaman dan contoh-contoh transaksi yang ada dalam 
Bank Syariah dan hal ini justru diharapkan sebagai pemicu untuk selalu dilakukan pengamatan, pembahasan dan diskusi-diskusi tentang akuntansi Bank Syariah sehingga menuju kesempurnaan.

Jika diperhatikan cakupan PSAK 59 tentang perbankan syariah digunakan untuk perbankan syariah yaitu Bank Umum Syariah, Bank Perkreditan Rakyat Syariah, Cabang Syariah dari Bank Konvensional, sehingga entitas syariah lain seperti asuransi syariah multifinance syariah koperasi syariah dsb belum tentu tunduk pada PSAK tersebut. Dengan adanya perkembangan entitas syariah yang cukup pesat di Indonesia maka, PSAK 59 direvisi dan disempurnakan dan disahkan oleh Dewan Standard Akuntansi Keuangan tahun 2007, serta mulai dipergunakan tahun buku 2008. PSAK syariah yang baru dimulai dengan nomor urut 101 sd 199, dimana PSAK syariah tersebut cakupannya diperluas tidak hanya untuk perbankan syariah, tetapi lembaga keuangan syariah lainnya seperti asuransi, Lembaga Pembiayaan termasuk koperasi syariah. 


\section{Tujuan Akuntansi Bank Syariah dan Tujuan Laporan Keuangan Bank Syariah}

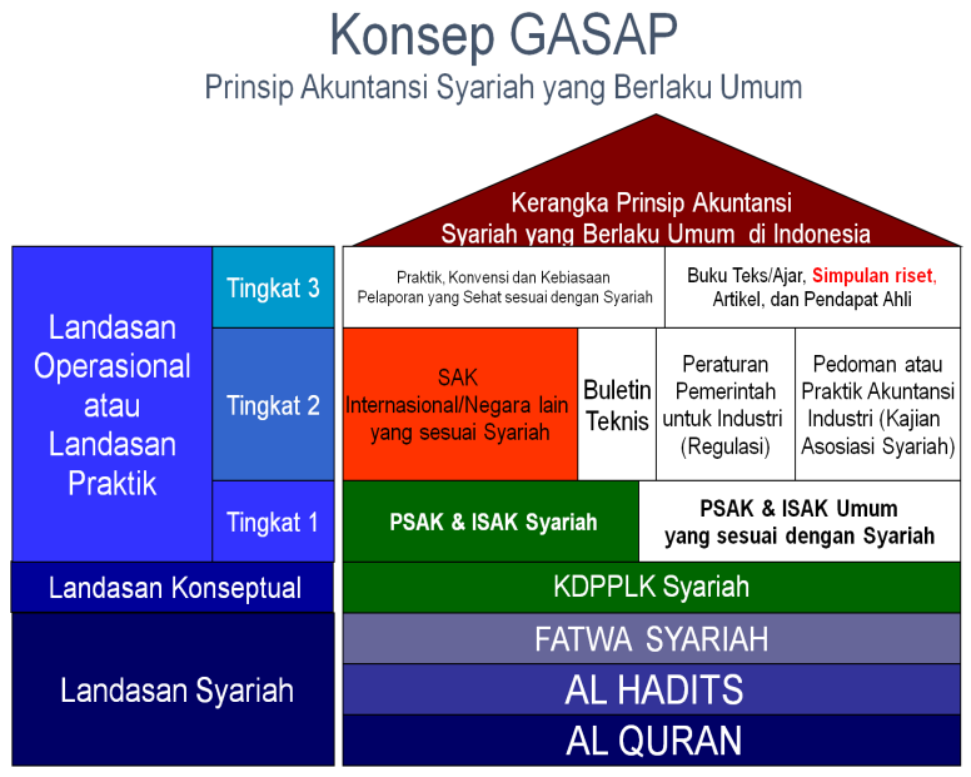

Gambar diatas menunjukkan kerangka prinsip akuntansi syariah yang berlaku umum di Indonesia. 


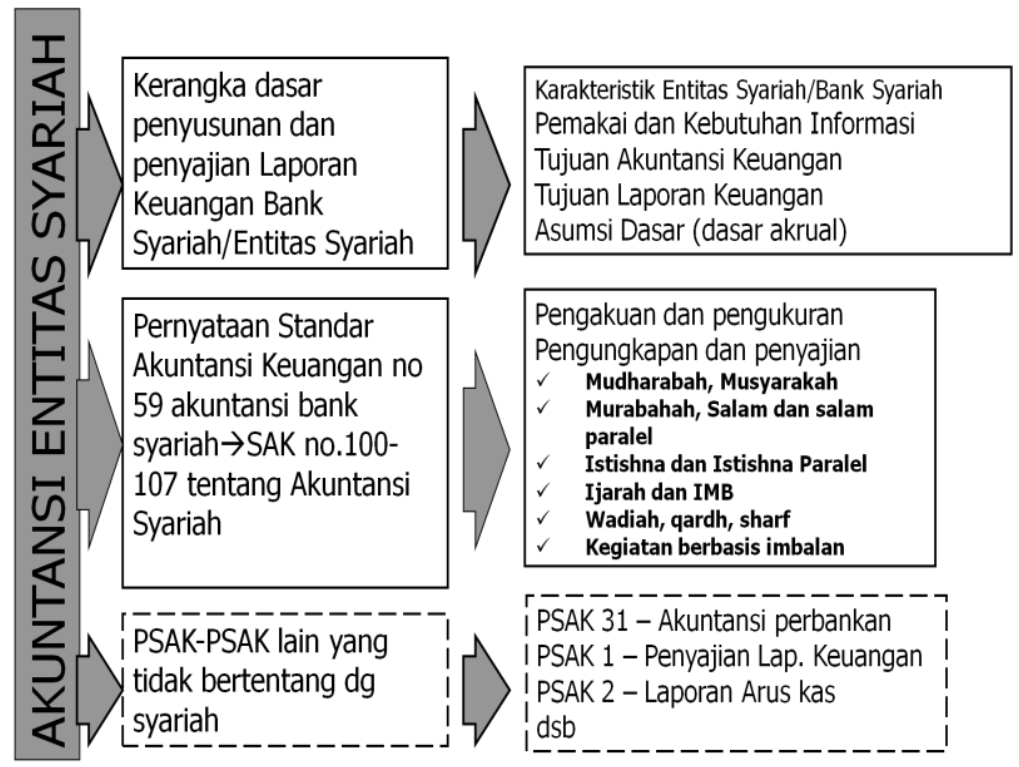

\section{Tujuan Akuntansi Bank Syariah}

1. Menentukan hak dan kewajiban pihak terkait, termasuk hak dan kewajiban yang berasal dari transaksi yang belum selesai dan atau kegiatan ekonomi lain, sesuai dengan prinsip syariah yang berlandaskan pada konsep kejujuran, keadilan, kebijakan, dan kepatuhan terhadap nilai-nilai bisnis Islami;

2. Menyediakan informasi keuangan yang bermanfaat bagi para pemakai laporan dalam pengambilan 
keputusan; dan tujuan akuntansi dan laporan keuangan bank syariah

3. Meningkatkan kepatuhan terhadap prinsip syariah dalam semua transaksi dan kegiatan usaha.

\section{Tujuan Laporan Keuangan Bank Syariah}

1. Pengambilan putusan investasi dan pembiayaan. Laporan keuangan bertujuan menyediakan informasi yang bermanfaat bagi pihakpihak yang berkepentingan dalam pengambilan keputusan yang rasional. Oleh karena itu, informasi harus dapat dipahami oleh pelaku bisinis dan ekonomi yang mencermati informasi yang disajikan dengan seksama. Pihak-pihak yang berkepentingan antara lain :

1. Shahibul maal / pemilik dana

2. Kreditur

3. Pembayar zakat, infaq dan shadaqah

4. Pemegang saham

5. Otoritas pengawasan

6. Bank Indonesia

7. Pemerintah

8. Lembaga penjamin simpanan; dan

9. Masyarakat 


\section{Menilai prospek arus kas.}

Pelaporan keuangan bertujuan untuk memberikan informasi yang dapat mendukung investor / pemilik dana, kreditur dan pihak-pihak lain dalam memperkirakan jumlah, saat dan ketidakpastian dalam penerimaan kas dimasa depan atas deviden, bagi hasil, dan hasil dari penjualan, pelunasan (redemption), dan jatuh tempo dari surat berharga atau pinjaman. Prospek penerimaan kas tersebut sangat tergantung dari kemampuan bank untuk menghasilkan kas guna memenuhi kewajiban yang telah jatuh tempo, kebutuhan operasional, reinvestasi dalam operasi, serta pembayaran deviden. Presepsi investor pemilik dana dan kreditur dipengaruhi oleh harapan mereka atas tingkat bagi hasil dan risiko dari dana yang mereka tanamkan. Investor pemilik dana dan kreditur akan memaksimalkan pengembalian dana yang telah mereka tanamkan dan akan melakukan penyesuaian terhadap risiko yang mereka presepsikan atas perusahaan yang bersangkutan. tujuan akuntansi dan laporan keuangan bank syariah. 


\section{Informasi atas sumber daya ekonomi.}

Pelaporan keuangan bertujuan memberikan informasi tentang sumberdaya ekonomis bank (economic resources), kewajiban bank untuk mengalihkan sumber daya tersebut kepada entitis lain atau pemilik sama, serta kemungkinan terjadinya transaksi, dan peristiwa yang dapat mempengaruhi perubahan sumber daya ekonomi tersebut. tujuan akuntansi dan laporan keuangan bank syariah.

\section{Kepatuhan bank terhadap prinsip syariah.}

Laporan keuangan memberikan informasi mengenai kepatuhan bank terhadap prinsip syariah, serta informasi pendapatan dan beban yang tidak sesuai dengan prinsip syariah dan bagaimana pendapatan tersebut diperoleh serta penggunaannya.

\section{Laporan keuangan memberikan informasi}

Untuk membantu mengevaluasi pemenuhan tanggung jawab bank terhadap amanah dalam mengamankan dana, menginvestasikannya pada tingkat keuntungan yang layak, dan informasi mengenai tingkat keuntungan investasi yang 
diperoleh pemilik dan pemilikdana investasi terikat; dan tujuan akuntansi dan laporan keuangan bank syariah.

\section{Pemenuhan fungsi sosial}

Laporan keuangan memberikan informasi mengenai pemenuhan fungsi sosial bank, termasuk pengelolaan dan penyaluran zakat. tujuan akuntansi dan laporan keuangan bank syariah

Laporan keuangan tidak hanya mencakup pernyataan mengenai keuangan tetapi juga merupakan sarana komunikasi informasi yang berhubungan baik secara langsung maupun tidak dengan informasi yang disediakan oleh akuntansi keuangan. tujuan akuntansi dan laporan keuangan bank syariah. Sasaran-sasaran dari akuntansi keuangan menentukan jenis dan sifat informasi yang harus dimasukkan di dalam laporan keuangan guna membantu para pemakai laporan ini di dalam mengambil keputusan.Oleh karena itu, sasaransasaran dari akuntansi keuangan harus memfokuskan pada kebutuhan informasi bersama dari para pemakai yang tidak mempunyai otoritas atau kemampuan untuk mendapatkan secara langsung informasi yang mereka perlukan, atau 
mengakses informasi tersebut. Fokus ini adalah karena dua alasan, yaitu kemampuan para pemakai untuk mendapatkan informasi yang mereka perlukan untuk mengambil keputusan secara langsung dari entitas; dan kebutuhan akuntan untuk melakukan pilihan diantara berbagai kebutuhan informasi yang bersaing dari berbagai pemakai karena keterbatasannya dalam memasukkan hal-hal apa saja yang dapat dimasukkan di dalam laporan keuangan.

Namun demikian, tidak berarti bahwa laporan keuangan yang memfokuskan pada kebutuhan informasi bersama dari para pemakai yang mempunyai akses terhadap informasi yang terbatas itu tidak bermanfaat bagi orang lain. tujuan akuntansi dan laporan keuangan bank syariah. Kategori utama para pemakai laporan keuangan eksternal bagi bank-bank Islam yang kebutuhan informasinya dibahas di dalam laporan ini meliputi: tujuan akuntansi dan laporan keuangan bank syariah

1. Modal pemilik

2. Pemilik rekening invetasi

3. Deposan lainnya

4. Pemilik rekening dan tabungan 
5. Orang lain yang melakukan transaksi bisnis dengan bank Islam, yang bukan pemilik atau pemilik rekening

6. Lembaga zakat (seandainya tidak ada kewajiban hukum untuk membayarnya)

7. Lembaga-lembaga pengatur.

Kebutuhan informasi dari para pemakai laporan keuangan meningkatkan dan berubah dengan meningkatnya kategori para pemakai, misalnya investor termasuk modal pemilik dan pemilik rekening invetasi, kreditor termasuk deposan jangka pendek (current depositor), deposan penabung (savings depositor), debtors, para pegawai bank Islam, lembaga-lembaga keuangan dan perbankan lain, dan mereka yang berurusan dengan bank-bank Islam dalam hal lain. tujuan akuntansi dan laporan keuangan bank syariah

Lembaga pemerintah mempunyai kekuasaan dan otoritas untuk secara langsung memperoleh jenis-jenis informasi yang paling sesuai dengan kebutuhan mereka. Sebaliknya, para pemakai eskternal lainnya terbatas pada informasi yang termuat di dalam laporan keuangan bank Islam. Oleh karena itu, adalah penting bahwa kebutuhan informasi bersama dari 
kategori para pemakai ini merupakan fokus dari laporan keuangan. Tetapi harus ditekankan bahwa laporan keuangan tidak bisa diharapkan akan memberikan setiap informasi yang mungkin yang dibutuhkan dari kategori pemakai ini karena pertimbangan biaya, terutama untuk kebutuhan yang tidak lazim bagi para pemakai lainnya.

\section{Siklus Akuntansi Bank Syariah}

Siklus Akuntansi syariah sama dengan akuntansi modern yang diawali dari transaksi bersamaan dengan bukti transaksi sampai pada laporan keuangan yang nantinya dijadikan sebagai pengambilan keputusan.

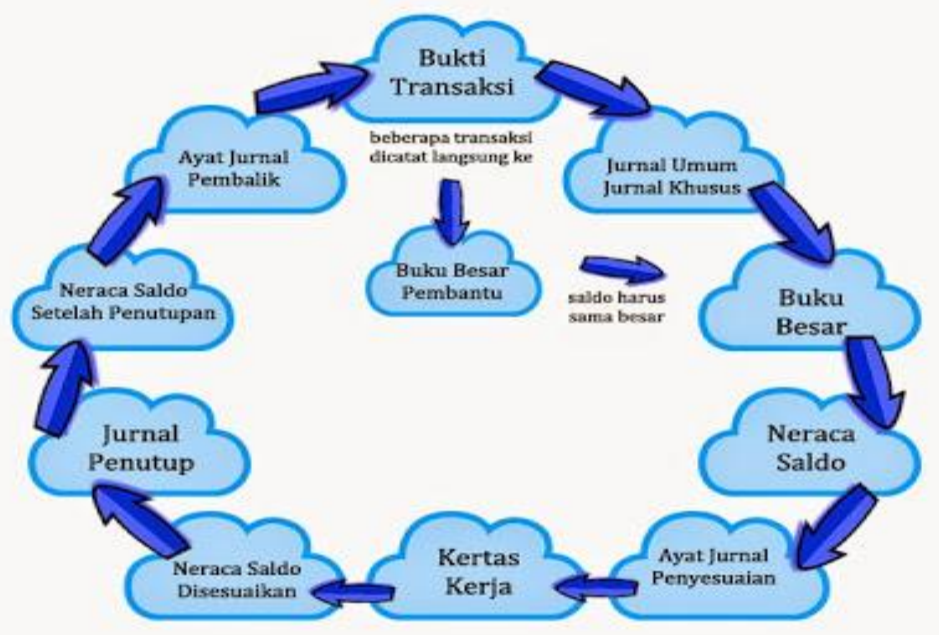




\section{Asumsi dasar, Pengakuan Akuntansi dan Konsep Pengukuran Akuntansi Perbankan Syariah}

\section{- Pengakuan Akuntansi}

Pengakuan Pendapatan. Prinsip dasar untuk pengakuan pendapatan adalah bahwa pendapatan harus diakui ketika diperoleh. Perolehan pendapatan terjadi apabila syarat-syarat yang berikut ini terpenuhi:

1. Bank harus sudah mendapatkan hak untuk menerima pendapatan tersebut. Ini berarti bahwa proses perolehan harus sudah selesai dan benar-benar selesai. Titik dimana proses perolehan selesai bisa berbeda untuk berbagai jenis pendapatan. Misalnya, proses perolehan untuk pendapatan dari jasa, selesai ketika bank menyerahkan jasa; proses perolehan untuk pendapatan dari penjualan barang selesai ketika pengiriman barang tersebut; dan proses perolehan untuk pendapatan dari membolehkan pihak lain menggunakan asset bank (misalnya menyewakan real estate) selesai ketika berjalannya waktu. 
2. Harus ada kewajiban di pihak lain untuk mengirim sejumlah tertentu atau yang bisa ditentukan kepada bank. pengukuran dan pengakuan akuntansi syariah

3. Jika belum tertagih, jumlah pendapatan harus diketahui dan harus bisa ditagih dengan tingkat kepastian yang cukup. pengukuran dan pengakuan akuntansi syariah

\section{- Pengakuan Biaya.}

Prinsip dasar bagi pengakuan biaya adalah realisasi atau perolehan baik karena biaya tersebut berhubungan secara langsung dengan pendapatan yang telah diperoleh dan diakui maupun karena berhubungan dengan jangka waktu yang dicakup oleh laporan laba/rugi.Pengakuan biaya ini ditegakkan di atas konsep bahwa Islam menetapkan tanggung jawab untuk biaya kepada penerima manfaat biaya tersebut. Biaya-biaya yang tidak mempunyai hubungan langsung dengan pendapatan tetapi mempunyai hubungan langsung dengan periode dimana pendapatan tersebut diakui masuk ke dalam kategori: 
1. Biaya-biaya yang mencerminkan cost yang memberikan manfaat pada periode sekarang tetapi tidak diharapkan untuk memberikan manfaat yang bisa diukur di masa yang akan datang. Contoh-contohnya termasuk kompensasi dan bonus dan biaya-biaya administratif lainnya yang sulit untuk mengalokasikannya secara langsung kepada jasa-jasa tertentu yang dilakukan untuk orang lain oleh bank atau asset tertentu yang dibeli oleh bank. Oleh karena itu, biaya-biaya tersebut harus diakui pada saat terjadinya. pengukuran dan pengakuan akuntansi syariah.

2. Biaya-biaya yang mencerminkan cost yang dialami oleh bank yang diharapkan memberikan manfaat selama beberapa periode. Biaya tersebut harus dialokasikan secara rasional dan sistematis pada periode yang diharapkan menerima manfaat 
tersebut. Suatu contoh dari biaya-biaya tersebut adalah depresiasi asset tetap yang mencerminkan suatu alokasi cost dari asset tetap kepada periode-periode yang mendapat manfaat dari penggunaan asset tersebut. pengukuran dan pengakuan akuntansi syariah.

\section{- Pengakuan Laba dan Rugi.}

Prinsip dasar dari pengakuan laba dan rugi adalah pada saat realisasi sebagai akibat dari: pengukuran dan pengakuan akuntansi syariah.

1. Selesainya transfer resiprokal atau nonresiprokal yang berasal dari keuntungan atau kerugian. Contoh dari transfer resiprokal adalah berakhirnya penjualan asset tetap sebagai suatu dasar pengakuan keuntungan (kerugian). Suatu contoh dari transfer nonresiprokal adalah terjadinya suatu kejadian seperti bencana alam yang menimbulkan krugian.

2. Tersedianya alat bukti yang kompeten dan memadai yang menunjukkan apresiasi atau 
depresiasi nilai asset atau kewajiban yang telah dicatat dan bisa diukur, sebagai akibat dari perubahan pada permintaan dan penawaran.Keuntungan dan kerugian tersebut merupakan keuntungan dan kerugian yang belum direalisir akibat revaluasi asset dan kewajiban, apabila hal itu dapat diterapkan.

3. Pengakuan keuntungan dan kerugian investasi terbatas.Prinsip-prinsip dasar yang mengatur pengakuan keuntungan dan kerugian juga mengatur pengakuan keuntungan dan kerugian investasi terbatas. Keuntungan dan kerugian investasi terbatas bisa terdiri dari dua jenis, yaitu keuntungan dan kerugian yang diperoleh dari transfer resiprokal dan non-resiprokal dan estimasi keuntungan/kerugian yang belum bisa direalisir akibat revaluasi investasi terbatas, apabila hal itu bisa diterapkan. pengukuran dan pengakuan akuntansi syariah 


\section{Konsep Pengakuan Akuntansi}

1. Konsep Matching

Untung / rugi bersih selama jangka waktu tertentu harus ditentukan dengan mencocokkan pendapatan dan keuntungan dengan biaya-biaya dan kerugian yang berhubungan dengan periode atau jangka waktu tersebut sesuai dengan prinsip-prinsip dasar pengakuan akuntansi. Demikian juga, keuntungan netto atau kerugian netto investasi terbatas harus ditentukan dengan mencocokkan pendapatan dan keuntungan investasi terbatas dengan biaya dan kerugian investasi yang berhubungan dengan periode atau jangka waktu tersebut sesuai dengan prinsipprinsip dasar pengakuan akuntansi. Konsep matching atau pencocokan didukung oleh konsep tanggung jawab biaya terhadap penerima manfaat.

2. Sifat-sifat Pengukuran. Sifat pengukuran mengacu kepada sifat-sifat asset dan kewajiban yang harus diukur untuk tujuan akuntansi keuangan. Misalnya, sifat asset yang bisa dipilih untuk pengukuran di dalam akuntansi keuangan bisa mencakup biaya perolehan asset, net realizable value atau cash equivalent value dari asset pada tanggal tertentu, biaya penggantian asset pada tanggal tertentu atau sifat 
lain yang pengukurannya akan menghasilkan informasi yang relevan. Pilihan sifat yang harus diukur untuk tujuan akuntansi keuangan harus didasarkan pada relevansi, kehandalan, kemampuan untuk dipahami dan kemampuan untuk dibandingkan dari informasi yang dihasilkan yang diberikan kepada para pemakai laporan keuangan.

\section{Sifat-Sifat yang harus diukur, pengukuran dan pengakuan akuntansi syariah.}

1. Nilai setara kas yang diharapkan atau diperkirakan diperoleh atau dibayarkan. Nilai setara kas yang diharapkan diperoleh adalah jumlah unit moneter yang akan diperoleh jika sebuah asset dijual tunai di dalam kegiatan bisnis secara normal pada tanggal sekarang. Nilai setara kas yang diharapkan akan dibayar adalah jumlah unit moneter yang diperlukan untuk melunasi kewajiban pada tanggal sekarang seperti kewajiban Salam atau Istisna'. Ketika semua syarat yang diharuskan untuk pengukuran sifat-sifat ini (relevansi, kehandalan dan kemampuan untuk dipahami dari informasi yang dihasilkan) terpenuhi, 
pengukuran sifat ini akan cocok untuk dijadikan dasar pengakuan akuntansi sebuah bank Islam dimana bank tersebut dapat bertindak sebagai :

○ seorang investor dari dana-dana yang tersedia baginya dari pemilik modal dan pemilik rekening investasi tidak terbatas atas dasar akad Mudharabah tidak terbatas

○ seorang manager investasi dari rekening investasi terbatas baik atas dasar Mudharabah terbatas maupun agency contract.

Pada kedua kasus tersebut, informasi yang berasal dari pengukuran sifat ini terutama relevan bagi para pemilik rekening investasi tidak terbatas dan rekening investasi terbatas atau setaranya, baik pemilik sekarang maupun yang potensial. Para pemilik rekening investasi (terbatas atau tidak terbatas) dan sejenisnya memerlukan informasi untuk mengevaluasi kemungkinan bank untuk mencapai sasaransasaran investasi mereka. Disamping itu, para pemilik rekening investasi dan sejenisnya memerlukan informasi untuk mengevaluasi alternatif yang tersedia bagi mereka 
apabila mereka bisa merubah hubungan mereka dengan bank tersebut.

Selain mempertimbangkan kedua hal di atas, pemilik rekening investasi pun perlu mempertimbangkan faktor-faktor lain, seperti nilai setara kas yang diharapkan dapat diperoleh dari dana-dana yang telah dia berikan atau akan diberikan kepada bank untuk membiayai investasi terbatas atau investasi terbatas. Nilai yang diharapkan diperoleh oleh seorang pemilik rekening investasi dari dana-dananya adalah sangat tergantung pada nilai setara kas yang diharapkan dapat diperoleh dari investasi tersebut, apabila investasi dijual pada tanggal sekarang.

Faktor penting lainnya yang memerlukan pengukuran sifat ini adalah alokasi yang adil dari hasil-hasil investasi terbatas antara para pemilik rekening investasi tidak terbatas yang telah menyediakan atau menarik dana pada berbagai titik waktu selama umur investasi tersebut, di satu sisi, dan antara para pemilik rekening tersebut sebagai suatu kelompok dan para pemilik bank Islam di sisi lain. Tidak seperti para pemilik bank Islam, para pemilik rekening investasi dan sejenisnya bisa menarik dana-dana mereka pada akhir akad mereka. Ini berarti bahwa jika investasi tidak terbatas ingin 
diukur pada biaya perolehannya (historis), akan timbul ketidak adilan di dalam pembagian hasil-hasil investasi antara para pemilik rekening investasi yang menyediakan atau menarik dana pada berbagai titik selama umur investasi itu. Demikian juga, akan timbul ketidak adilan di dalam pembagian hasil-hasil investasi tidak terbatas antara para pemilik rekening investasi tidak terbatas sebagai suatu kelompok dan para pemilik bank Islam.

Pertimbangan ini juga relevan untuk para pemilik rekening investasi terbatas atau sejenisnya yang telah menyediakan atau menarik dana-dana pada berbagai titik selama umur investasi terbatas. Hasil-hasil dari investasi (laba dan rugi) tidak terjadi pada suatu titik tertentu. Namun demikian, hasilhasil tersebut diperoleh selama umur investasi meskipun hasil akhir yang diperoleh belum pasti, sampai investasi tersebut diakhiri. Jika investasi terbatas ingin diukur pada biaya perolehannya sampai diakhiri, hasil-hasil investasi hanya dapat diakui selama periode tersebut, pada saat investasi tersebut diakhiri. Jika kasusnya seperti ini akan muncul ketidak adilan antara para pemilik rekening investasi terbatas yang telah menyediakan atau menarik dana pada berbagai titik waktu selama umur investasi tersebut. 
1. Revaluasi asset, Kewajiban dan investasi terbatas pada akhir periode akuntansi. Pengukuran setara kas yang diharapkan akan diperoleh atau dibayar memerlukan revaluasi secara berkala terhadap asset, kewajiban dan investasi terbatas yang beredar (outstanding). Tetapi, informasi yang dihasilkan harus bisa dipercaya dan bisa dibandingkan. Untuk menjamin kehandalan dan kemampuan untuk dibandingkan, manajemen bank Islam wajib mematuhi semua prinsipprinsip dasar berikut ini selama revaluasi asset, kewajiban dan investasi terbatas tersebut adalah sebagai berikut:

a. Harus menggunakan indikator-indikator luar (seperti harga pasar), sejauh mana indikatorindikator tesebut tersedia.

b. Harus memanfaatkan semua informasi yang relevan apakah positif atau negatif.

c. Harus menggunakan Metode penilaian yang logis dan relevan.

d. Konsistensi dalam menggunakan metode penilaian

e. Sejauh mana relevan, para pakar di dalam valuasi harus digunakan. 
f. Konservatisme di dalam proses penilaian dengan berpegang kepada objektivitas dan netralitasdidalam memilih nilai-nilai.

g. Kemampuan asset, kewajiban dan investasi terbatas untuk direvaluasi. Meskipun revaluasi asset, kewajiban dan investasi terbatas itu relevan apabila investasi dibiayai oleh para pemilik rekening investasi, konsep ini tidak akan diadopsi saat ini. Hal ini disebabkan karena tidak adanya bukti bahwa sarana yang memadai sat ini tersedia untuk menerapkan konsep ini sesuai dengan cara yang mungkin akan menghasilkan informasi yang bisa diandalkan atau dipercaya. Namun demikian konsep boleh diterapkan dengan tujuan untuk menyajikan informasi tambahan yang mungkin relevan bagi pemilik rekening investasi yang ada atau seorang calon pemilik rekening investasi. Penyajian informasi tambahan tersebut tidak mewajibkan bank Islam untuk membagikan hasil-hasil investasi yang belum diperoleh. Pembagian hasil-hasil investasi dan sifat hasil-hasil yang akan dibagikan umumnya 
berdasarkan pada hubungan akad antara bank Islam dan pemilik rekening investasi dan hukum serta peraturan yang mengatur hubungan tersebut.

2. Sifat pengukuran alternatif terhadap nilai setara kas (cash equivalent value). Biaya historis dari asset mengacu kepada nilai pasarnya pada tanggal perolehannya termasuk jumlah yang dikeluarkan untuk membuatnya bisa dipakai atau siap untuk digunakan. Nilai pasar pada tanggal perolehan mengacu kepada harga yang dibayar oleh bank Islam untuk membeli asset dalam suatu transaksi lugas (arm's length transaction) antara pihakpihak yang tidak berkaitan pada tanggal transfer. Biaya historis dari suatu kewajiban mengacu kepada jumlah yang diterima oleh bank Islam ketika kewajiban tersebut terjadi atau jumlah dimana kewajiban tersebut akan diselesaikan apabila dilakukan.

\section{Persamaan Dasar Akuntansi Perbankan Syariah}

Aktiva $=$ Kewajiban + Modal

Karena karakteristiknya akuntansi Bank Syariah mempunyai persamaan akuntansi yang berbeda dengan persamaan akuntansi umum atau akuntansi bank 
konvensional, persamaan akuntansi pada unsur neraca bank syariah adalah :

\section{Aktiva $=$ Kewajiban + Investasi Tidak Terikat + Modal}

\section{Laporan Keuangan Perbankan Syariah}

\section{Tujuan Laporan Keuangan}

Berdasarkan paragraf 30 KDPPLKS dinyatakan bahwa tujuan laporan keuangan menurut KDPPLKS adalah menyediakan informasi yang menyangkut posisi keuangan, kinerja serta perubahan posisi keuangan suatu entitas syariah yang bermanfaat bagi sejumlah besar pemakai dalam pengambilan keputusan ekonomi.

Tujuan lainnya adalah :

> Meningkatkan kepatuhan terhadap prinsip syariah dalam semua transaksi dan kegiatan usaha.

> Informasi kepatuhan entitas syariah terhadap prinsip syariah, serta informasi aset, kewajiban, pendapatan dan beban yang tidak sesuai dengan prinsip syariah bila ada dan bagaimana perolehan dana penggunaannya. 
> Informasi untuk membantu mengevaluasi pemenuhan tanggung jawab entitas syariah terhadap amanah dalam mengamankan dana, menginvestasikannya pada tingkat keuntungan yang layak.

$>$ Informasi mengenai tingkat keuntungan investasi yang diperoleh penanam modal dan pemilik dana syirkah temporer dan informasi mengenai pemenuhan kewajiban fungsi sosial entitas syariah, termasuk pengelolaan dan penyaluran zakat, infaq, sedekah dan wakaf.

Laporan keuangan juga menunjukkan apa yang telah dilakukan manajemen (stewardship) atau pertanggungjawaban manajemen atas sumber daya yang dipercayakan kepadanya. 
Asumsi Dasar dalam laporan keuangan

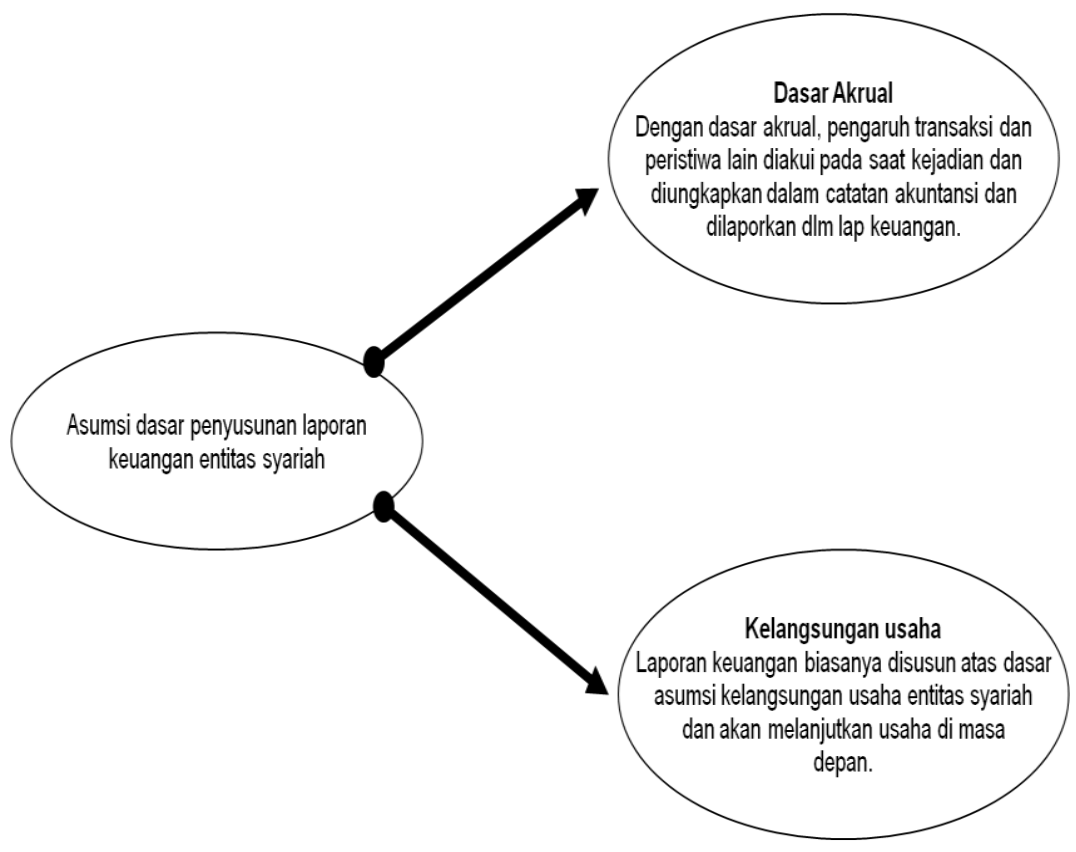

Karakteristik kualitatif informasi keuangan syariah

Karakteristik Kualitatif Pokok :

1. Dapat Dipahami, adalah pemakai diasumsikan memiliki pengetahuan yang dapat memadai tentang aktivitas ekonomi dan bisnis.

2. Relevan, adalah memilihi kemampuan untuk mempengaruhi keputsan ekonomi pamakai dengan 
membantu mereka mengevaluasi masa lalu, kini dan depan.

3. Handal, Dikatakan handal apabila bebas dari pengertian yang menyesatkan kesalahan materi dan disajikan dengan jujur.

4. Dapat dibandingkan, Pemakai harus dapat memperbandingkan keuangan entitas syariah antar periode untuk mengidentifikasi posisi dan kinerja keuangan.

\section{UNSUR-UNSUR LAPORAN KEUANGAN}

Unsur-unsur laporan keuangan entitas syariah berdasarkan karakteristikya ((KDPPLKS paragraph 68):

1. Laporan keuangan yang mencerminkan kegiatan komersial meliputi laporan keuangan, laporan laba rugi, laporan arus kas, dan laporan perubahan ekuitas.

2. Komponen laporan keuangan yang mencerminkan kegiatan social, komponen ini meliputi laporan sumber dan penggunaan dana zakat.

3. Komponen laporan keuangan lainnya yang mencerminkan tanggung jawab khusus entitas syariah. 
Diantara berbagai laporan tersebut, laporan posisi keuangan dan laporan laba rugi merupakan dua laporan keuangan utama.

\section{Laporan Keuangan Bank Syariah}

Laporan keuangan yang mencerminkan kegiatan bank syariah sebagai investor beserta hak dan kewajibannya, yang dilaporkan dalam :

i. Laporan Posisi Keuangan/Neraca

Laporan ini menggambarkan dampak keuangan dari transaksi dan peristiwa lain yang diklasifikasikan dalam beberapa kelompok besar menurut karakteristik ekonominya (KDDPLKS par 69) 
Format Laporan posisi keuangan / Neraca Bank Syariah

PT Bank Syariah "X"

Laporan Posisi Keuangan (Neraca)

Per 31 Desember $20 \times 2$ dan $20 \times 1$

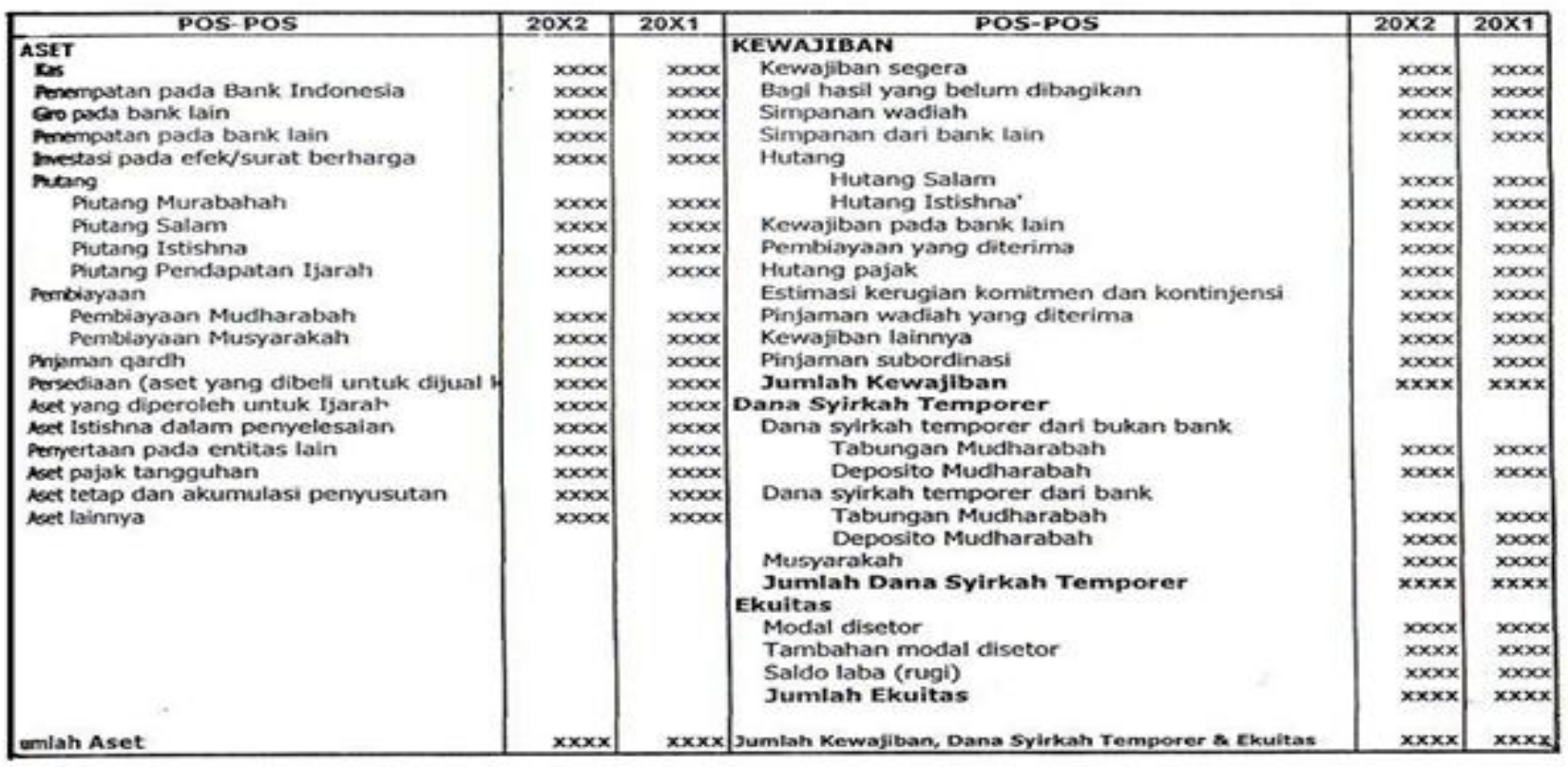


ii. Laporan Laba Rugi

Laporan laba rugi adalah ukuran kinerja entitas syariah yang juga merupakan dasar bagi

ukuran yang lain, seperti Imbalan investasi atau penghasilan per saham

Format laporan Laba Rugi Bank Syariah

PT. Bank Syariah "X"

Laporan Laba Rugi

Periode 1 Januari s/a 31 Desember $20 \times 2$ dan $20 \mathrm{X}_{1}$

\begin{tabular}{|c|c|c|}
\hline POS-POS & $20 \times 2$ & $20 \times 1$ \\
\hline 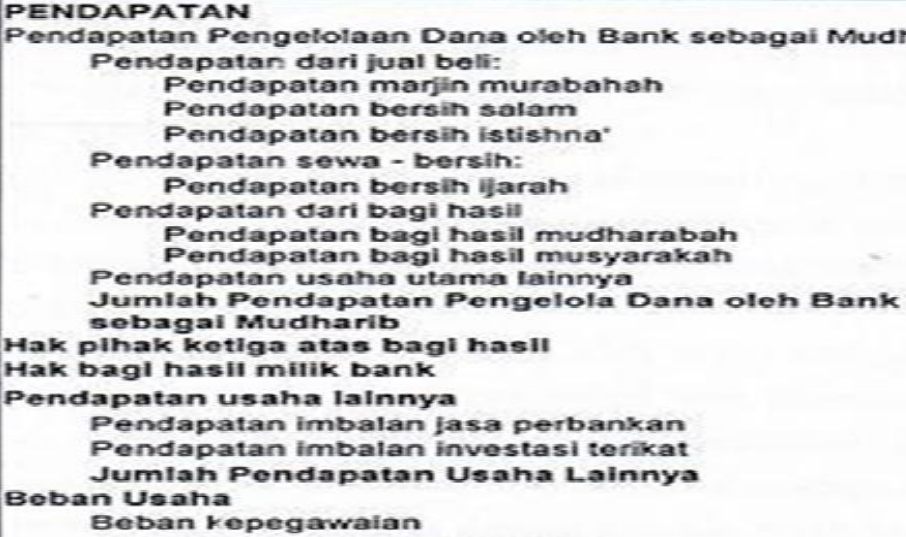 & 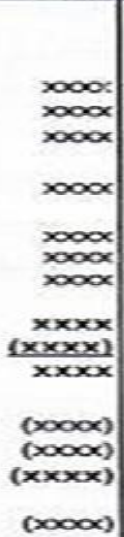 & 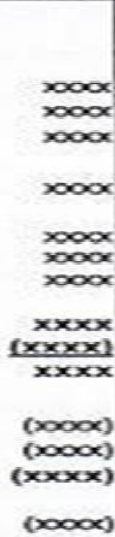 \\
\hline
\end{tabular}




\begin{tabular}{|c|c|c|}
\hline $\begin{array}{l}\text { Beban administrasi dan umum } \\
\text { Beban penyusutan dan amortisasi } \\
\text { Beban penyisihan keruglan aktiva produktif } \\
\text { Beban estimasi kerugian komitmen dan kontinjensi } \\
\text { Beban bonus giro wadiah } \\
\text { Beban lain-lain } \\
\text { Jumlah Boban Usaha } \\
\text { Laba (Rugi) Usaha } \\
\text { Pendapatan dan Beban Nonusaha } \\
\text { Pendapatan nonusaha } \\
\text { Jumlah Pendapatan (Beban) Nonusaha } \\
\text { Jumlah Pendapatan (Beban) Nonusaha } \\
\text { Laba (Rugi) Sebelum Pajak } \\
\text { Beban Pajak } \\
\text { Zakat* } \\
\text { Laba (Rugi) Bersih Periode Berjalan }\end{array}$ & 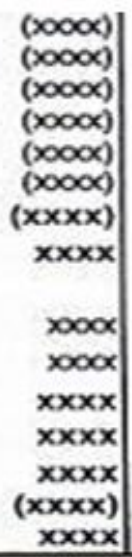 & 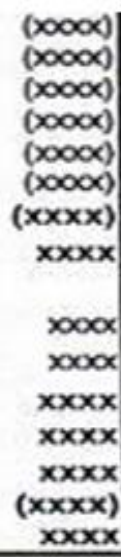 \\
\hline
\end{tabular}




\section{EVALUASI}

1. Jelaskan prinsip dan asumsi dasar akuntansi syariah.

2. Jelaskan tujuan dari laporan keuangan perbankan syariah

3. Jelaskan persamaan dan perbedaan laporan keuangan yang ada di bank syariah dan bank konvensional 


\section{BAGIAN 6 \\ AKUNTANSI PENGHIMPUNAN DANA}

\section{Tujuan Instruksional Umum}

1. Menjelaskan prinsip-prinsip penghimpunan dana dalam Perbankan Syariah

2. Memahami perlakuan akuntansi penghimpunan dana dalam Perbankan Syariah

3. Menjelaskan cara penghimpunan dana dengan Prinsip Wadiah

4. Menjelaskan cara penghimpunan dana dengan Prinsip Mudharabah

5. Menjelaskan Standar Akuntansi Bank Syariah menurut PSAK No. 59 tentang Akuntansi Bank Syariah

6. Memahami perlakuan Akuntansi penghimpunan dana dengan Prinsip Wadiah

7. Memahami perlakuan Akuntansi penghimpunan dana dengan Prinsip Mudharabah 


\section{SUB POKOK BAHASAN}

\section{Gambaran Umum Perbankan Syaiah}

Sistem keuangan dan perbankan islam merupakan bagian dari konsep yang lebih luas tentang ekonomi islam dimana tujuannya sebagaimana dianjurkan oleh para ulama, adalah memberlakukan sistem nilai dan etika islam ke dalam lingkungan ekonomi. Karena dasar etika inilah, maka keuangan dan perbankan islam bagi kebanyakan muslim adalah bukan sekedar sistem transaksi komersial. Persepsi islam dalam transaksi finansial itu dipandang oleh banyak kalangan muslim sebagai kewajiban agama. Kemampuan keuangan lembaga islam menarik investor dengan sukses bukan hanya tergantung pada tingkat kemampuan lembaga itu menghasilkan keuntungan, tetapi juga pada persepsi bahwa lembaga tersebut secara sungguh-sungguh memperhatikan batas-batas yag digariskan oleh islam.

\section{Penghimpunan dana Prinsip Wadiah}

Wadiah dapat diartikan sebagai titipan dari satu pihak ke pihak lain, baik individu maupun badan hukum yang harus dijaga dan dikembalikan kapan sja spenyimpan menghendakinya. Tujuan dari perjanjian tersebut adalah 
untukmenjaga keselamatan barang itu dari kehilangan, kemusnahan, kecurian dan sebagainya. Yang dimaksud dengan "barang" disini adalah suatu yang berharga seperti uang, dokumen, surat berharga dan barang lain yangberhara disisi islam.

Adapun rukun yang harus dipenuhi dalam transaksi dengan prinsip wadiah adalah sebagai berikut :

a. Barang yang dititipkan

b. Orang yang menitipkan/ penitip

c. Orang yang menrima titipan/ penerima titipan, dan

d. Ijab Qabul

Wadiah terdiri dari dua jenis, yaitu:

1. Wadiah Yad Al Amanah, merupakan titipan murni, barang yang dititipkan tidak bolehdigunakan (diambil manfaatnya) oleh penitip, sewaktu titipan dikembalikan harus dalam keadaan utuh baik nilai maupun fisik barangnya, jika selama dalam penitipan terjadi kerusakan maka pihak yang menerima titipan tidak dibebani tanggung jawab, sebagai kompensasi atas tanggung jawab pemeliharaan dapat dikenakan biaya penitipan. 
2. Wadiah Yad Ad Dhamanah, merupakan pengembangan dari Wadiah Yad Al Amanahyang disesuaikan dengan aktifitas perekonomian. Penerima titipan diberi izin untuk menggunakan dan mengambil manfaat dari titipan tersebut. Penyimpan mempunyai kewajiban untuk bertanggung jawab terhadap kehilangan/ kerusakan barang tersebut. Semua keuntungan yang diperoleh dari titipan tersebut menjadi hak penerima titipan. Sebagai imbalan kepada pemilik barang/ dana dapat diberikan semacam insentif berupa bonus, yang tidak disyaratkan sebelumnya.

Wadiah Yad Ad Dhamanah dalam Bank Islam dapat diaplikasikan pada Rekening giro (current account) dan Rekening tabungan (saving account).

\section{Giro Wadiah}

Giro wadiah adalah titipan pihak ketiga pada bank syariah yang penarikannya dapat dilakukan setiap saat dengan menggunakan cek, bilyet giro, kartu ATM, sarana perintah pembayaran lainnya atau dengan cara pemindah bukuan. Termasuk di dalamnya giro wadiah yang diblokir untuk 
tujuan tertentu misalnya dalam rangka escrow account, giro yang diblokir oleh yang berwajib karena suatu perkara.

Dalam Fatwa Dewan Syariah Nasional ditetapkan ketentuan tentang Giro Wadiah (Himpunan Fatwa, Edisi kedua, hal 6-7) sebagai berikut:

a. Bersifat titipan

b. Titipan bisa diambil kapan saja (on call)

c. Tidak ada imbalan yang disyaratkan, kecuali dalam bentuk pemberian (athaya) yang bersifat sukarela dari pihak bank.

Karakteristik dari giro wadiah antara lain:

a. Harus dikembalikan utuh seperti semula sehingga tidak boleh overdarft

b. Dapat dikenakan biaya titipan

c. Dapat diberikan syarat tertentu untuk keselamatan barang titipan misalnya menetapkan saldo minimum

d. Penarikan giro wadiah dilakukan dengan cek dan bilyet giro sesuai ketentuan yang berlaku

e. Jenis dan kelompok rekening sesuai dengan ketentuan yang berlaku sepanjang tidak bertentangan dengan syariah. Dana wadiah hanya dapat digunakan seijin penitip 


\section{Tabungan Wadiah}

Tabungan wadiah adalah titipan pihak ketiga pada bank syariah yang penarikannya dapat dilakukan menurut syarat tertentu yang disepakati dengan kuitansi, kartu ATM, sarana perintah pembayaran lainnya atau dengan cara pemindah bukuan.Simpanan yang penarikannya hanya dapat dilakukan menurut syarat tertentu yang disepakati, tetapi tidak dapat ditarik dengan cek atau alat yang dapat dipersamakan dengan itu. Dalam fatwa Dewan Syariah Nasional ditetapkan ketentuan Tabungan Wadiah sebagai berikut:

a. Bersifat simpanan

b. Simpanan bisa diambil kapan saja (on call) atau berdasarkan kesepakatan. Tidak ada imbalan yang disyaratkan, kecuali dalam bentuk pemberian yang bersifat sukarela dari pihak bank.

\section{Penghimpunan dana Prinsip Mudharabah}

Dalam mengaplikasikan prinsip mudharabah, penyimpan atau deposan betindak sebagai shahibul maal (pemilik modal) dan bank sebagai mudharib (pengelola). Dana tersebut digunakan bank untuk melakukan murabahah atau ijarah dapat pula dna tersebut digunakan 
bank unuk melakukan mudharabah ke dua. Hasil usaha ini akan dibagi hasilkan berdasarkn nisbah yang disepakati.Dalam hal bank menggunakan nya untuk melakukan mydharabah kedua, maka bank bertanggung jawab penuh atas kerugian yang terjadi.

Rukun mudharabah terpenuhi sempurna bila ada yaitu :

a. Ada mudharib

b. Ada pemilik dana

c. Ada usaha yang akan dibagi hasilkan

d. Ada nisbah

e. Ada ijab qabul

Berdasarkan kewenangan yang diberikan oleh pihak penyimpan dana, prinsip mudharabah terbagi menjadi dua yaitu :

1. Mudharabah Mutlaqah ( investasi tidak terikat)

Mudharabah Mutlaqah merupakan salah satu produk dari Musyarakah, dimana dana merupakan $100 \%$ milik bank. dana ini dapat digunakan untuk kegiatan usaha nasabah sesuai kehendak nasabah. Bank yang memiliki produk seperti ini harus betul-betul selektif dalam memilik calon debitur/nasabah, karena resiko yang ditanggung bank adalah 100\% dari dana yang disalurkan. Oleh karena itu biasanya Produk 
Mudharabah terkait dengan Projek-projek singkat yang berasalah dari pemerintah atau perusahaan yang kredible dan nasabah yang kompeten dan terpercaya dalam mengerjakannya.

2. Mudharabah Muqayyadah ( investasi terikat)

Perbedaan Mudharabah Muqayadah dengan Mutlaqah adalah disisi penggunaan dana yang diterima nasabah. penggunaannya terikat syaratsyarat dari pemilik dana. Waktu dan jenis usaha sudah ditentukan sebelumnya. Bank mempertemukan pemilik dana dan calon debitur/nasabah dan memfasilitasi pencairan dana dan penerimaan angsuran modal dan bagi hasil dari nasabah. Bank akan mendapatkan jasa/fee dari kegiatan ini.

\section{Tabungan Mudharabah}

Tabungan adalah simpanan yang penrikannya hanya dapat dilakukan menurut syarat tertentu yang disepakati, tetapi tidak dapat ditarik dengan cek atau alat yang dipersamakan dengan itu.

Akuntansi untuk tabungan mudharabah dan penghimpunan dana bentuk lainnya menggunakan akad mudharabah pada dasarnya mengacu pada PSAK 105 
tentang Akuntansi Mudharabah, khususnya yang terkait dengan akuntansi untuk pengelola dana. Berdasarkan PSAK 105 paragraf 25, dinyatakan bahwa dana yang diterima dari pemilik dana (nasabah penabung) dalam akad mudharabah diakui sebagai dana syirkah temporer sebesar jumlah kas atau nilai wajar aset non-kas yang diterima. Pada akhir periode akuntansi, dana syirkah temporer diukur sebesar nilai tercatatnya.

\section{Deposito Mudharabah}

Deposito adalah investasi dana berdasarkan akad mudharabah yang tidak bertentangan dengan prinsip syariah yang penarikannya hanya dapat dilakukan hanya pada waktu tertentu berdasarkan akad antara nasabah (penyimpan) dengan bank syariah (Unit Usaha Syariah). Perbedaannya dengan deposito konvensional adalah terlihat pada akad dan sistem bagi hasil yang ditawarkan. Dalam fatwa Dewan Syariah Nasional Nomor 3 Tahun 2000 , tentang deposito mudharabah yaitu :

b. Di sini nasabah disebut sebagai pemilik dana atau shahibul maal dan bank disebut sebagai pengelola dana atau mudharib. 
c. Modal deposito yang diberikan shahibul maal harus dalam bentuk tunai.

d. Bank sebagai mudharib berhak lakukan berbagai usaha asalkan tidak melenceng pada prinsip syariah dan mnembangkannya, rmasuk didalamnya mudharabah dengan pihak lain.

e. Bank menggunakan nisbah keuntungan yang menjadi haknya untuk menutupi biaya operasional deposito.

f. Bank tidak boleh mengurangi nisbah keuntungan tanpa persetujuan nasabah.

\section{Standar Akuntansi Bank Syariah menurut PSAK No. 50 tentang Akuntansi Bank Syariah \\ Perlakuan Akuntansi Perbankan Syariah}

Sisi perekonomian merupakan bagian terpenting bagi umat islam, namun pada perkembangannya sistem ekonomi yang berkembang seperti sosialis dan kapitalis memberikan peluang ketidak merataan distribusi pendapatan dalam masyarakat, sedangkan islam menghendaki adanya sistem adil yang tidak merugikan salah satu pihak, untuk itulah muncul sebuah konsep yang disebut syari'ah. 
Mewujudkan keselarasan antara pertumbuhan dan pemerataan membutuhkan sebuah lembaga yang mampu mengendalikan dan mengatur dinamika ekonomi yaitu berupa uang dan barang.Fungsi itulah yang kemudian di kenal sebagai Bank, disitulah terjadi pertemuan antara pemilik, pengguna dan pengelola modal yang pada hakikatnya banyak membawa manfaat terhadap pihak masing-masing.

Bank merupakan lembaga keuangan yang usaha pokoknya memberikan kredit dan jasa-jasa dalam lalu lintas pembayaran dan peredaran uang. Dalam hal ini konsepkonsep islam telah diterapkan pada lembaga keuangan perbankan ini, sehingga muncullah konsep perbankan syari'ah. Bank syariah dalam menjalankan usahanya mengutamakan konsistensi penerapan prinsip syariah dengan menggunakan sistem non bunga dan penerapan kualitas pelayanan syariah, Sistem non bunga bank syariah dalam istilah ekonomi diartikan dengan pembagi laba, secara definisi diartikan sebagai distribusi beberapa bagian dari laba pada para pegawai suatu perusahaan.

Konsep bunga dalam bank konvensional inilah dianggap sebagai riba, dimana kebanyakan bank konvensional tidak memberikan toleransi pemberian kredit kepada golongan yang dianggap memiliki skala usaha kecil dan tidak memiliki 
agunan, sehingga golongan-golongan masyarakat kecil yang tidak memiliki agunan dan prospek usaha yang besar akan kesulitan memperoleh pendanaan modal terutama dari kredit perbankan, karena bank-bank menilai bahwa mereka tidak mempunyai kemampuan untuk mengembalikan pinjaman.

Untuk itulah diperlukan sebuah konsep yang menjadi alternatif dari perbankan dalam mewujudkan kesejahteraan masyarakat. Alternatif itulah yang ekonomi islam yang pada perkembangannya mengembangkan konsep-konsep syariah yang di kembangkan dalam dunia perbankan. Dalam konsep perbangkan konvensional yang berkembang sistem bunga, selalu ada satu pihak yang menanggung kerugian atau resiko, pihak-pihak peminjam adalah pihak yang paling dirugikan atas pembebanan bunga dan penanggungan atas tingkat resiko yang mungkin terjadi terhadap kegiatan pinjam- meminjam atau pendanaan permodalan tersebut. Hal inilah yang tidak di kembangkan atau di kenal dalam konsep perbankan syari'ah, karena tidak ada istilah bunga dalam konsep ekonomi islam bank syariah merupakan lembaga keuangan yang melaksanakan perantara keuangan dari pihakpihak yang kelebihan dana kepada pihak-pihak lain yang membutuhkan berdasarkan prinsip-prinsip ajaran agama Islam. Prinsipprinsip tersebut yang paling utama adalah tidak 
diperkenankannya perbankan untuk meminta atau memberikan bunga kepada nasabahnya.

Bank syari'ah memiliki produk-produk atau jasa yang tidak ditemukan dalam operasi bank-bank syariah, yaitu berupa prinsip-prinsip syari'ah, diantaranya mudharabah, murabaha, musyarakah, ijarah, ijarah wa iqtina, wadiah, dll. Sistem syari' ah ini tidak memuat adanya bungan sebagaiman yang di kembangkan dalam bank-bank konvensional. Prinsip prinsip yang berbeda antara bank syari'ah dan bank konvensional menjadikan penyajian dalam laporan keuanganpun juga berbeda, di mana laporan keuangan ini merupakan bagian ringkasan proses pencatatan dari transaksitransaksi keuangan yang terjadi selama satu tahun bersangkutan, sebagai pertanggung jawaban manajer terhadap para pemilik perusahaan.

Berdasarkan PSAK no 59, di nyatakan bahwa salah satu sumber untuk memperoleh kepercayaan publik adalah dengan membentuk tingkat kualitas informasi yang baik terhadap publik, dimana bank syariah harus mampu meyakinkan publik bahwa mereka memiliki kemampuan dan kapasitas di dalam mencapai tujuan-tujuan financial maupun tujuan-tujuan yang sesuai dengan syariat Islam. Karena itu, membangun sebuah sistem akuntansi dan audit yang bersifat standar telah 
menjadi kebutuhan utama yang harus dipenuhi, menyangkut pengakuan, pengukuran, penyajian, dan pengungkapan dalam sebuah sistem akuntansi.

Salah satu permasalahan yang selama ini di hadapi perbankan syari'ah adalah masalah standarisasi sistem akuntansi dan audit, yang bertujuan untuk menciptakan transparansi keuangan sekaligus memperbaiki kualitas pelayanan keuangan terhadap masyarakat. Adapun perkembangan dari perbankan syariah sendiri di Indonesia masih belum optimal, hal ini terutama di sebabkan oleh karena kurangnya sosialisasi sistem perbankan syari'ah, landasan hukum dan kerangka pengaturan yang belum sesuai, pembiayaan yang belum mencerminkan hakikat bank syariah yang sesungguhnya, dan belum terpenuhinya norma dan standart internasional yang berlaku.

Komponen-komponen laporan keuangan dalam bank syari'ah menurut PSAK no 59 berisi pengungkapan umum laporan keuangan, serta tanggal efektif untuk penyusunan dan penyajian laporan keuangan lemaga syari' ah. 


\section{EVALUASI}

1. Jelaskan produk bank syariah terkait dengan produk penghimpunan dana.

2. Apa kelebihan yang ditawarkan produk tersebut dibandingkan dengan produk sejenis yang ada di bank konvensional.

3. Bagaimana perlakuan akuntansi untuk perbankan syariah sesuai dengan PSAK no.59. 


\section{BAGIAN 7}

\section{AKUNTANSI MURABAHAH}

\section{Tujuan Instruksional Umum}

1. Memahami konsep dasar Akuntansi Murabahah

2. Memahami ketentuan-ketentuan dalam Akuntansi Murabahah

3. Menjelaskan standar akuntansi yang digunakan dalam Akuntansi Murabahah

4. Memahami perlakuan Akuntansi Murabahah

5. Menjelaskan pengertian dasar Akuntansi Murabahah

6. Menjelaskan ketentuan-ketentuan dalam Akuntansi Murabahah

7. Menjelaskan standar Akuntansi Murabahah dalam PSAK No. 59 tentang Akuntansi Bank Syariah

8. Memahami perlakuan Akuntansi Murabahah

\section{SUB POKOK BAHASAN}

\section{Pengertian dasar Akuntansi Murabahah}

Murabahah adalah akad jual beli barang dengan menyatakan harga perolehan dan keuntungan (marjin) yang disepakati oleh penjual dan pembeli. 
Rukun Transaksi Murabahah

a. Transaktor ( pihak yang bertransaksi ) yaitu penjual dan pembeli

b. Objek murabahah yaitu barang yang diperjual belikan

c. Ijab dan Qabul

\section{Ketentuan-ketentuan dalam Akuntansi Murabahah}

a. Pembolehan penggunaan murabahah didasarkan pada Al-Quran surat Al Baqarah ayat 275 yang menyatakan bahwa Allah telah menghalalkan jual beli dan mengharamkan riba.

b. Ketentuan syar'i terkait transakasi murabahah, digariskan oleh fatwa dewan syariah Nomor 04/DSN-MUI/IV/2000.

\section{Rukun Transaksi Murabahah}

Rukun transaksi murabahah meliputi transaktor, yaitu adanya pembeli (nasabah) dan penjual (bank syariah), objek akad murabahah yang didalamnya tekandung barang dan harga, serta ijab dan qabul berupa pernyataan 
kehendak masing masing pihak, baik dalam bentuk ucapan maupun perbuatan.

a. Transaktor (pihak yang bertransaksi) terdiri dari pembeli (nasabah) dan penjual (bank syariah), transaktor di syaratkan memiliki kompetensi berupa akil baligh dan kemampuan memilih yang optimal, seperti tidak gila, tidak terpaksa, dan lainnya. Adapun transaksi dengan anak kecil dapat dilakukan dengan izin dan pantauan dari walinya.

b. Objek murabahah, meliputi barang dan harga barang yang diperjual belikan, barang tersebut tidak boleh barang yang diharamkan oleh syariah islam.

Objek jual beli harus memenuhi :

1. Barang yang diperjual belikan adalah barang halal

2. Barang yang diperjual belikan harus dapat diambil manfaatnya

3. Barang tersebut dimiliki oleh penjua

4. Barang tersebut dapat diserahkan tanpa tergantung dengan kejadian tertentu dimasa depan.

5. Barang tersebut harus diketahui secara spesifik dan dapat diidentifikasikan oleh pembeli sehingga tidak ada gharar (ketidakpastian). 
6. Barang tersebut dapat diketahui kuantitas dan kualitasnya degan jelas

7. Harga barang tersebut jelas

8. Barang yang diakadkan ada di tangan penjual

c. Ijab dan kabul, merupakan kehendak pihak yang bertransaksi baik itu secara lisan maupun tertulis, atau secara diam diam. Pernyataan dan ekspresi saling rida/rela diantara pihak-pihak pelaku akad yang dilakukan secara verbal, tertulis, melalui korespondensi atau menggunakan cara-cara komunikasi modern. Apabila jual beli telah dilakukan sesuai dengan ketentuan syariah maka kepemilikannya, pembayarannya dan pemanfaatan atas barang yang diperjualbelikan menjadi halal. Demikian sebaliknya. Kalau kita perhatikan, semua ketentuan syariah diatas tidak ada yang memberatkan. Semuanya masuk akal, memiliki nilai moral yang tinggi, menghargai hak kepemilikan harta, meniadakan persengketaan yang dapat berakibat pada permusuhan.

Akad ini bersifat mengikat dan mencantumkan berbagai hal yaitu : 
1. Nama notaris serta informasi tentang waktu dan tempat tanda tangan

2. Identitas pihak pertama, bank syariah (biasanya kepala cabang)

3. Identitas pihak kedua, dalam hal ini nasabah yang akan membeli barang dengan didampingi suami/istri yang bersangkutan sebagai ahli waris

4. Bentuk akad beserta penjelasan akad

Pengawasan syariah transaksi murabahah

1. Memastikan barang transaksi tidak diharamkan syariah

2. Memastikan harga jual senilai harga beli plus margin

3. Meneliti akad wakalah dan pembiayaan berdasarkan prinsip murabahah

Standar akuntansi Murabahah dalam PSAK No. 59 tentang Akuntansi Bank Syariah

\section{Perlakuan Akuntansi Murabahah}

1. Pengakuan dan pengukuran urbun ( uang muka ) : 
a. Urbun diakui sebagai uang muka pembelian sebesar jumlah yang diterima bank pada saat diterima

b. Jika transaksi murabahah dilaksanakan, maka urbun diakui sebagai pembayaran piutang ( bagian angsuran pembelian )

c. Jika transaksi tidak dilaksanakan, maka urbun dikembalikan kepada nasabah setelah dikurangi dengan biaya yang telah dikeluarkan bank

d. Pengakuan piutang Pada saat akad murabahah, piutang murabahah diakui sebesar nilai perolehan ditambah keuntungan yang disepakati

2. Pengakuan keuntungan murabahah diakui :

a. Pada periode terjadinya, apabila akad berakhir pada periode laporan keuangan yang sama

b. Selain periode akad secara proporsional, apabila akad melampaui satu periode laporan keuangan.

c. Pengakuan potongan pelunasan dini diakui dengan menggunakan salah satu metode :

- Pada saat penyelesaian, bank mengurangi piutang murabahah dan keuntungan murabahah. 
d. Setelah penyelesaian, bank terlebih dahulu meminta pelunasan murabahah dari nasabah, kemudian bank membayar pengakuan potongan kepada nasabah dengan mengurangi keuntungan murabahah.

e. Pengakuan denda diakui sebagai dana kebajikan pada saat diterima

f. Pada akhir periode, piutang murabahah disajikan sebesar nilai bersih yang dapat direalisasikan.

g. Pada akhir periode, margin murabahah tangguhan disajikan sebagai pos lawan piutang murabahah.

\section{EVALUASI}

1. Sebut dan jelaskan rukun akad murabahah.

2. Sebutkan ketentuan transaski murabahah.

3. Bagaimana perlakuan akuntansi murabahan sesuai dengan PSAK no.59. 


\section{BAGIAN 8 \\ AKUNTANSI SALAM}

\section{Tujuan Instruksional Umum}

1. Memahami konsep dasar Akuntansi Salam

2. Memahami ketentuan-ketentuan dalam Akuntansi Salam

3. Menjelaskan standar akuntansi yang digunakan dalam Akuntansi Salam

4. Memahami perlakuan Akuntansi Salam

5. Menjelaskan pengertian dasar Akuntansi Salam

6. Menjelaskan ketentuan-ketentuan dalam Akuntansi Salam

7. Menjelaskan standar Akuntansi Salam dalam PSAK No. 59 tentang Akuntansi Bank Syariah

8. Memahami perlakuan Akuntansi Salam

\section{SUB POKOK BAHASAN}

\section{Pengertian dasar Akuntansi Salam}

Bai' as salam atau biasa disebut dengan salam, merupakan pembelian barang yang pembayarannya dilunasi di muka sedangkan penyerahan barang dilakukan di kemudian hari. 
Akad salam ini digunakan untuk memfasilitasi pembelian suatu barang (biasanya barang hasil pertanian) yang memerlukan waktu untuk memproduksinya.

Salam paralel merupakan jual beli barang yang melibatkan dua transaksi salam, dalam hal ini transaksi salam pertama dilakukan dilakukan antara nasabah dengan bank, sedang transaksi salam kedua dilakukan antara bank dengan petani atau pemasok.

\section{Ketentuan-ketentuan dalam Akuntansi Salam}

Landasan syar'i dibolehkannya transaksi salam adalah sebagaimana disebutkan dalam hadis Nabi SAW riwayat Ibnu Abbas berikut:

"Barang siapa yang melakukan salaf (salam) hendaknya ia melakukan dengan takaran yang jelas dan timbangan yang jelas pula, untuk jangka waktu yang diketahui." Ketentuan syar'i transaksi salam diatur dalam fatwa DSN no 05/DSN-MUI/IV/2000 tentang Jual Beli Salam. Fatwa tersebut mengatur tentang ketentuan pembayaran, barang, salam paralel, waktu penyerahan dan syarat pembatalan kontrak.

Rukun-rukun salam meliputi: 
a. transaktor yakni pembeli (muslam) dan penjual (muslam ilaih);

b. objek akad salam berupa barang dan harga yang diperjualbelikan dalam transaksi salam; dan

c. ijab dan kabul yang menunjukkan pernyataan kehendak jual beli secara salam, baik berupa ucapan atau perbuatan.

7. Standar akuntansi Salam dalam PSAK No. 59 tentang Akuntansi Bank Syariah

Pengakuan dan Pengukuran Salam. PAR 69-80.

4. Salam adalah akad jual beli muslam fiih (barang pesanan) dengan penangguhan pengiriman oleh muslam ilaihi (penjual) dan pelunasannya dilakukan segera oleh pembeli sebelum barang yang dipesan tsb diterima sesuai dengan syarat-syarat tertentu .

5. Salam parallel berarti melaksanakan dua transaksi bai' as-salam antara bank dengan nasabah, dan antara bank dan pemasok (supplier) atau pihak ketiga lainnya.( (Muhammad Syafi'I Antonio, 2001:110) 
Bank dapat bertindak sebagai pembeli (muslam) atau penjual dalam suatu transaksi salam. Jika bank bertindak sebagai penjual kemudian memesan kepada pihak lain untuk menyediakan barang pesanan dengan cara salammaka hal ini disebut salam pararel, yaitu dilakukan dengan syarat:

a. Akad kedua antara bank dan pemasok terpisah dari akad pertama antara bank dan pembeli akhi

b. Akad kedua dilakukan setelah akad pertama sah

c. Spesifikasi dan harga barang pesanan disepakati oleh pembeli dan penjual di awal akad. Ketentuan harga barang pesanan tidak dapat berubah selama jangka waktu akad.Dalam hal bank bertindak sebagai pembeli, bankb syariah dapat meminta jaminan kepada nasabah untuk menghindari risiko yang merugikan bank.

d. Barang pesanan harus diketahui karakteristiknya secara umum yang meliputi: jenis, spesifikasi teknis, kualitas, dan kuantitasnya. Barang pesanan harus sesuai dengan karakteristik yang telah disepakati antara pembeli dan penjual.Jika barang pesanan yang dikirimkan salah atau cacat maka penjual harus bertanggung jawab atas kelalaiannya. 


\section{Akuntansi Salam dan Salam Paralel}

1. Piutang salam diakui pada saat modal salam dibayarkan atau dialihkan kepada penj

2. Transaksi salam paralel diakui sebagai kewajiban pada saat bank menerima modal salam berupa kas atau aktiva non-kas.

3. Modal salam dapat berupa:

a. kas diukur sebesar jumlah yang dibayarkan,

b. aktiva non-kas diukur sebesar nilai wajar.

4. Pengakuan dan pengukuran penerimaan barang pesanan:

a. barang pesanan cocok, dinilai sesuai nilai akad;

b. jika barang pesanan berbeda kualitas:

1. jika nilai pasar $>=$ nilai (akad) barang pesanan, dinilai sesuai akad.

2. jika jika nilai pasar < nilai (akad) barang pesanan, dinilai sebesar nilai pasar dan diakui kerugian.

c. Jika bank tak menerima sebagian/seluruh barang pesanan:

1) piutang salam tetap sesuai akad, jika tanggal pengiriman diperpanjang; 
d. jika bank tak menerima sebagian/seluruh barang pesanan:

1) piutang salam berubah menjadi piutang jatuh tempo oleh nasabah sebesar bagian yang tidak dapat dipenuhi, jika akad salam dibatalkan.

2) jika ada jaminan atas barang pesanan:

a) hasil penjualan jaminan < nilai piutang salam, selisihnya diakui sebagai piutang jatuh tempo kepada nasabah, atau

b) hasil penjualan jaminan > nilai piutang salam, selisihnya menjadi hak nasabah.

3) bank dapat mengenakan denda kepada nasabah.

e. Barang pesanan yang telah diterima:

1) diakui sebagai persediaan;

2) pada akhir periode, persediaan diukur sebesar nilai terendah antara biaya perolehan dan nilai tunai yang dapat direalisasi, dan;

3) jika nilai tunai yang dapat direalisasi lebih rendah maka selisihnya diakui sebagai kerugian pada laporan laba rugi.

f. Apabila bank melakukan transaksi salam paralel: 
1) selisih antara jumlah yang dibayar oleh nasabah dan biaya perolehan barang pesanan diakui sebagai keuntungan atau kerugian pada saat pengiriman barang pesanan oleh bank ke nasabah.

\section{Perlakuan Akuntansi Salam \\ Pengakuan \& Pengukuran}

Seperti yang disebutkan dalam PSAK No. 103, bahwa Salam adalah akad jual beli muslam fiih (barang pesanan) dengan penangguhan pengiriman oleh muslam ilaihi (penjual) dan pelunasannya dilakukan segera oleh pembeli sebelum barang pesanan tersebut diterima sesuai dengan syarat-syarat tertentu. Transaksi salam terjadi karena pembeli berniat memberikan modal kerja terlebih dahulu untuk memungkinkan penjual (produsen) menyediakan barangnya. Transaksi salam diselesaikan pada saat penjual menyerahkan barang kepada pembeli.

Dengan demikian transaksi Salam dilakukan karena pembeli berniat memberikan modal kerja terlebih dahulu untuk memungkinkan penjual (produsen) memproduksi barang yang diinginkannya melalui pesanan lebih dahulu.Barang yang dipesan memiliki spesifikasi khusus 
dan pembeli membutuhkan kepastian dari pihak penjual.Transaksi Salam berakhir pada saat penjual menyerahkan barang kepada pembeli.

Karakteristik dan harga barang harus sudah disepakati di awal akad.Jika ada ketidaksesuaian karakteristik barang yang dikirimkan ke pembeli maka menjadi tanggung jawab penjual.Ketentuan harga barang tidak dapat berubah selama jangka waktu akad.Alat pembayaran dapat berupa kas, barang atau manfaat. Pelunasan harus dilakukan pada saat akad disepakati dan tidak boleh dalam bentuk pembebasan hutang penjual atau penyerahan piutang pembeli dari pihak lain. Jaminan dapat diminta untuk menghindari risiko yang merugikan.

Pada situasi dimana pihak penjual tidak dapat menyediakan sendiri barang pesanan dari pembeli maka dilakukan Salam Paralel, yaitu entitas yang bertindak sebagai penjual kemudian memesan kepada pihak lain untuk menyediakan barang pesanan dengan transaksi Salam juga.

Ada kemungkinan kontrak salam dibatalkan oleh pembeli jika barang yang dipesan tidak tersedia pada waktu yang ditentukan, barang yang dikirim cacat atau 
tidak sesuai dengan yang disepakati dalam akad, dan barang yang dikirim kualitasnya lebih rendah.

\section{Penyajian}

Pada akhir periode pelaporan keuangan, persediaan yang diperoleh melalui transaksi salam diukur sebesar nilai terendah biaya perolehan atau nilai bersih yang dapat direalisasi. Apabila nilai bersih yang dapat direalisasi lebih rendah dari biaya perolehan, maka selisihnya diakui sebagai kerugian.

a. Pembeli menyajikan modal usaha salam yang diberikan sebagai Piutang salam.

b. Piutang yang harus dilunasi oleh penjual karena tidak dapat memenuhi kewajibannya dalam transaksi Salam disajikan secara terpisah dari Piutang salam.

c. Penjual menyajikan modal usaha salam yang diterima sebagai Hutang Salam.

\section{Pengungkapan}

Dalam catatan atas laporan keuangan, pembeli dan penjual dalam transaksi salam mengungkapkan hal-hal berikut : 
a. Besarnya modal usaha salam, baik yang dibiayai sendiri maupun yang dibiayai secara bersama-sama dengan pihak lain;

b. Jenis dan kuantitas barang pesanan; dan

c. Pengungkapan lain sesuai dengan PSAK N0. 101 tentang Penyajian Laporan Keuangan Syari'ah

\section{EVALUASI}

1. Jelaskan tentang akad Salam.

2. Bagaimana pengakuan, pengukuran dan pengungkapan akuntansi salam

3. Berikan contoh transaksi akuntansi salam. 


\section{BAGIAN 9}

\section{AKUNTANSI ISTISHNA}

\section{Tujuan Instruksional Umum}

1. Memahami konsep dasar Akuntansi Salam

2. Memahami ketentuan-ketentuan dalam Akuntansi Salam

3. Menjelaskan standar akuntansi yang digunakan dalam Akuntansi Salam

4. Memahami perlakuan Akuntansi Salam

5. Menjelaskan pengertian dasar Akuntansi Salam

6. Menjelaskan ketentuan-ketentuan dalam Akuntansi Salam

7. Menjelaskan standar Akuntansi Salam dalam PSAK No. 59 tentang Akuntansi Bank Syariah

8. Memahami perlakuan Akuntansi Salam

\section{SUB POKOK BAHASAN}

\section{Pengertian dasar Akuntansi Istishna}

Bai ' al istishna ' atau disebut dengan istishna', merupakan kontrak jual beli dalam bentuk pembuatan barang tertentu dengan kriteria dan persyaratan tertentu 
yang disepakati antara pemesan ( pembeli, mustahni' ) dan penjual ( pembuat, shani' ).

- Barang yang diperjualbelikan biasanya adalah barang manufaktur, adapun dalam hal pembayaran, transaksi istishna' dapat dilakukan di muka, melalui cicilan atau ditangguhkan sampai suatu waktu pada masa yang akan datang.

- Penggunaan akad istishna' oleh bank syariah diindonesia relatif masih minim.

\section{Ketentuan-ketentuan dalam Akuntansi Istishna}

Menurut mazhab Hanafi, istishna' hukumnya boleh karena hal itu telah dilakukan oleh masyarakat muslim sejak masa awal tanpa ada ulama yang mengingkari. Ketentuan syar'I transaksi istishna' diatur dalam fatwa DSN no 06/DSN-MUI/IV/2000 TENTANG jual beli istishna'

Fatwa tersebut mengatur tentang ketentuan pembayaran, dan ketentuan barang. 


\section{Rukun Transaksi Istishna}

a. Transaktor

Transaktor terdiri atas pembeli dn penjual. Kedua transaktor disyaratkanmemiliki kompetensi berupa akil baligh dan kemampuan memilih yang optimal seperti tidak gila, tidak sedang dipaksa dan yang lain sejenis.

Adapun untuk transaksi dengan anak kecil, dapat dilakukan dengan izin dan pantauan dari walinya.Terkait dengan penjual, DSN mengharuskan agar penjual menyerahkan barang tepat pada waktunya dengan kualitas dan jumlah yang telah disepakati.

Penjual diperbolekan menyerahkan barang lebih cepat dari waktu yang disepakati dengan syarat kualitas dan jumlah barang sesuai dengan kesepakatan dan ia tidak boleh menuntut tambahan harga.

\section{Objek Istishna'}

- harus jelas spesifikasinya

- penyerahanya dilakukan kemudian

- waktu dan tempat penyerahan barang harus ditetapkan berdasarkan kesepakatan

- pembeli ( mustashni' ) tidak boleh menjual barang sebelum menerimanya 
- tidak boleh menukar barang, kecuali dengan barang sejenis sesuai kesepakatan

- memerlukan proses pembuatan setelah akad disepakati;

- barang yang diserahkan harus sesuai dengan spesifikasi pemesan, bukan barang masal

b. Ijab dan kabul istishna' merupakan pernyataan dari kedua belah pihak yang berkontrak, dengan cara penawaran dari penjual ( bank syariah ) dan penerimaan yang dinyatakan oleh pembeli ( nasabah ) .

Menurut PSAK no 104 paragraf 12 pada dasarnya Istishna' tidak dapat dibatalkan, kecuali memenuhi kondisi :

- Kedua belah pihak setuju untuk menghentikannya

- Akad batal demi hukum karena timbul kondisi hukum yang dapat menghalangi pelaksanaan atau penyelesaian akad.

Berdassarkan fatwa DSN no 6 tahun 2000, disebutkan bahwa 
a. Akad istishna' (kedua antara bank sebagai pembeli dengan petani sebagai penjual ) harus dilakukan terpisah dari akad pertama .

b. Adapun akad kedua baru dilakukan setelah akad pertama sah, rukun-rukun yang

terdapat pada akad istishna' pertama juga berlaku pada akad istishna' kedua pengawasan tersebut dilakukan untuk :

1. Memastikan barang yang diperjualbelikan tidak diharamkan oleh syariah islam

2. Meneliti apakah bank membiayai pembuatan barang yang diperlukan nasabah sesuai pesanan dan kriteria yang disepakati.

3. Memastikan akad Istishna' dan akad Istishna' paralel dibuat dalam akad yang terpisah.

4. Memastikan bahwa akad Istishna' yang sudah dikerjakan sesuai kesepakatan hukumnya mengikat, artinya tidak dapat dibatalkan kecuali memenuhi kondisi antara lain (i) kedua belah pihak setuju untuk menghentikan akad Istishna' (ii) akad ini batal demi hukum karena timbul kondisi hukum yang dapat menghalangi pelaksanaan atau penyelesaian akad. 
Akuntansi istishna' diatur dalam Pernyataan Standar Keuangan ( PSAK ) no 104 tentang istishna'.terkait dengan pengakuan dan pengukuran transaksi, standar ini mengatur tentang penyatuan dan segmentasi akad, pendapatan istishna' dan istishna' parale, istishna'dengan pembayaran tangguh, biaya perolehan istishna', penyelesaian awal pengakuan taksiran rugi, perubahan pesanan dan tagihan.

\section{EVALUASI}

\section{Transaksi Istishna' Pertama}

Untuk mengembangkan klinik ibu dan anak yang dikelolanya, dr. Ursila berencana menambah satu unit bangunan seluas $100 \mathrm{~m}^{2}$ khusus untuk rawat inap di sebelah barat bangunan utama klinik. Untuk kebutuhan itu, dr. Ursila menghubungi Bank Berkah Syariah untuk menyediakan bangunan baru sesuai dengan spesifikasi yang diinginkannya. Setelah serangkaian negosiasi beserta kegiatan survey untuk menghasilkan desain bangunan yang akan dijadikan acuan spesifikasi barang, pada tanggal 10 Februari 20XA ditandatanganilah akad transaksi istishna' pengadaan bangunan untuk rawat inap. Adapun kesepakatan antara dr. Ursila dengan Bank Berkah Syariah adalah sebagai berikut: 
Harga Bangunan

Lama penyelesaian

10 Juli)

Mekanisme panagihan $\quad: \quad 5$ termin sebesar $\mathrm{Rp}$ 30.000.0000 pertermin mulai tanggal 10 Agustus

Mekanisme pembayaran : setiap 3 hari setelah tanggal penagihan

\section{Transaksi Istishna' Kedua}

Untuk membuat bangunan sesuai dengan keinginan dr. Ursila, pada tanggal 12 Februari 20XA, Bank Berkah Syariah memesan kepada kontraktor PT. Thariq Konstruksi dengan kesepakatan sebagai berikut:

Harga Bangunan

: Rp 130.000.000

Lama penyelesaian : 4 bulan 15 hari (paling lambat $\operatorname{tg} 125$ Juni)

Mekanisme penagihan kontraktor: tiga termin pada saat penyelesaian 20\%, 50\% dan $100 \%$.

Mekanisme pembayaran oleh Bank : dibayar tunai sebesar tagihan dari kontraktor.

Selesaikanlah soal kasus diatas. 


\section{BAGIAN 10}

\section{AKUNTANSI IJARAH}

\section{Tujuan Instruksional Umum}

1. Memahami konsep dasar, ketentuan-ketentuan yang berlaku, standar akuntansi yang digunakan dalam Akuntansi Ijarah

2. Memahami perlakuan Akuntansi Ijarah

3. Menjelaskan pengertian dasar Akuntansi Ijarah

4. Menjelaskan ketentuan-ketentuan dalam Akuntansi Ijarah

5. Menjelaskan standar Akuntansi Ijarah dalam PSAK No. 59 tentang Akuntansi Bank Syariah

6. Memahami perlakuan Akuntansi Ijarah

\section{SUB POKOK BAHASAN}

\section{Pengertian dasar Akuntansi Ijarah}

Ijarah dan ijarah Muntahiyah Bit tamlik (IMBT) merupakan transaksi sewa menyewayang diperbolehkan oleh syariah.Akad ijarah merupakan akad yang memfasilitasitransaksi pemindahan hak guna (maanfaat) 
atas suatu barang atau jasa dalam waktutertentu melalui pembayaran sewa/upah tanpa diikuti pemindahan kepemilikan barang.

Bagi bank syariah, transaksi ini memiliki beberapa keunggulan jika dibandingkan dengan jenis akad lainnya yaitu:

1. Dibandingkan dengan akad murabahah, akad ijarah lebih fleksibel dalam hal objek transaksi.

2. Dibandingkan dengan investasi, akad ijarah mengandung resiko usaha yang lebih rendah, yaitu adanya pendapatan sewa yang relatif tetap

4. Ketentuan-ketentuan dan standar akuntansi yang digunakan dalam Akuntansi Ijarah

Ketentuan syar'I Transaksi Ijarah dan Transaksi IMBT

Berdasarkan terminologi, Ijarah adalah pemindahkan kepemilikan fasilitas dengan imbalan. Penyewaan dalam sudut pandang islam meliputi dua hal yaitu;

1. Penyewaan terhadap potensi atau sumber daya manusia

2. Penyewaan terhadap suatu fasilitas

Ketentuan syar'I transaksi ijarah diatur dalam fatwa DSN no 09 tahun 2000. Adapun ketentuan syar'i transaksi ijarah untuk penggunaan jasa diatur dalam fatwa DSN no 
44 tahun 2004.Sedangkan ketentuan syar'i IMBT diatur dalam fatwa DSN no 27 tahun 2000.

\section{Rukun Transaksi Ijarah}

Rukun transaksi ijarah meliputi (a) transaktor yakni penyewa dan pemberi sewa, (b) objek ijarah, yakni fasilitas dan uang sewa; dan (3) ijab dan kabul menunjukkan searah terima, baik berupa ucapan atau perbuatan.

a. Transaktor

Transaktor terdiri atas penyewa (nasabah) dan pemberi sewa (bank syariah). Kedua transaktor disyaratkan memiliki kompetensi berupa akil baligh dan kemampuan memilih yang optimal seperti tidak gila, tidak sedang dipaksa dan yang lain yang sejenis. Impilikasi perjanjian sewa kepada bank syariah sebagai penyewa adalah sebagai berikut:

a. Menyediakan aset yang disewakan

b. Menanggung biaya pemeliharaan aset

c. Menjamin bila terdapat cacat pada aset yang disewakan 
Adapun kewajiban nasabah sebagai penyewa adalah:

a. Membayar sewa dan bertanggungjawab untuk menjaga keutuhan aset yang disewa serta menggunakannya sesuai kontrak.

b. Menanggung biaya pemeliharaan yang sifatnya ringan (tidak materiil).

Jika aset yang disewa rusak, bukan karena pelanggaran dari penggunaan yang dibolehkan, juga bukan karena kelalaian pihak penyewa dalam menjaganya, ia tidak bertanggung jawab atas kerusakan tersebut.Objek ijarah.

Objek kontrak ijarah meliputi pembayaran sewa dan manfaat dari penggunaan aset.

Adapun ketentuan objek ijarah adalah sebagai berikut:

1. Objek ijarah adalah maanfaat dari penggunaaan barang dan jasa

2. Manfaat barang harus bisa dinilai dan dapat dilaksanakan dalamkontrak.

3. Fasilitasnya mubah (dibolehkan).

4. Kesanggupan memenuhi maanfaat harus nyata dan sesuai dengansyariah. 
5. Manfaat harus dikenali secara spesifit sedemikian rupa untukmenghilangkanketidaktahuan yang akan mengakibatkan sengketa.

6. Spesifikasi manfaat harus dinyatakan dengan jelastermasukjangka waktunya.

7. sewa adalah sesuatu yang dijanjikan dan dibayar kepada LKSsebagai pembayaranmanfaat.

8. Ketentuan dalam menentukan sewa dapat diwujudkan dalamukuran waktutempat danjarak.

\section{Ijab dan Kabul.}

Ijab dan kabul dalam akad ijarah merupakan peryataan dari kedua belah pihak yang berkontrak, dengan cara penawaran dari pemilik aset (bank syariah) dan penerimaan yang dinyatakan oleh penyewa (nasabah).Berdasarkan fatwa DSN no 27 tahun 2002, disebutkan bahwa pihak yang melakukan transaksi IMBT harus melaksanakan akad ijarah terlebih dahulu. Dengan demikian pada akad IMBT, juga berlaku semua rukun dan syarat transaksi ijarah.Adapun akad perjanjian IMBT harus disepakati ketika akad ijarah ditandatangani.Selanjutnya pelaksanaan akad pemindahaan kepemilikan, baik dengan jual beli atau pemberian hanya dapat dilakukan setelah masa ijarah selesai. 


\section{Objek ijarah}

Objek kontrak ijarah meliputi pembayaran sewa dan manfaat dari penggunaan aset.

Adapun ketentuan objek ijarah adalah sebagai berikut:

1. Objek ijarah adalah maanfaat dari penggunaaan barang dan jasa.

2. Mafaat barang harus bisa dinilai dan dapat dilaksanakan dalam kontrak.

3. Fasilitasnya mubah (dibolehkan)

4. Kesanggupan memenuhi maanfaat harus nyata dan sesuai dengan syariah.

5. Manfaat harus dikenali secara spesifit sedemikian rupa untuk menghilangkan.

6. ketidaktahuan yang akan mengakibatkan sengketa.

7. Spesifikasi manfaat harus dinyatakan dengan jelas termasuk jangka waktunya.

8. sewa adalah sesuatu yang dijanjikan dan dibayar kepada LKS sebagai pembayaran manfaat.

9. Ketentuan dalam menentukan sewa dapat diwujudkan dalam ukuran waktu, tempat dan jarak. 


\section{Rukun Transaksi Ijarah Untuk Pembiayaan Multijasa}

Pembiayaan multijasa dengan skema ijarah adalah pembiayaan yang diberikan oleh Lembaga Keuangan Syariah (LKS) kepada nasabah dalam memperoleh manfaat atas suatu jasa dengan menggunakan akad ijarah, pembiayaan multijasa hukumnya boleh (jaiz) dengan menggunakan akad ijarah atau kafalah.

\section{CAKUPAN STANDAR AKUNTANSI IJARAH DAN IJARAH MUNTAHIYA BITTAMLIK}

Standar akuntansi untuk ijarah masih menggunakan PSAK no 59 bagian ijarah dan IMBT paragraf 105 sampai paragaf 133. Standar ini memuat tentang mekanisme transaksi dan ketentuan tentang pengakuan dan pengukuran transaksi dalam yang terdapat dalam skema ijarah dan IMBT. Beberapa hal dicakup dalam standar ini adalah pengakuan dan pengukuran perolehan objek ijarah, pendapatan ijarah dan IMBT, piutang pendapatan ijarah dan IMBT, biaya perbaikan yang dikeluarkan, perpindahan hal milik objek sewa, terjadinya penurunan nilai objek sewa secara permanen. 


\section{EVALUASI}

Untuk keperluan transaksi ijarah PT Namira di atas, pada tanggal 5 juni 20XA bank syariah membeli aset pada perusahaan yang mensuplai barang yang diperlukan. Pembelian dilakukan via rekening pemasok tersebut adalah sebagai berikut:

Misalkan untuk keperluan transaksi ijarah PT Namira di atas, pada tanggal 5 juni 20XA bank syariah membeli aset pada perusahaan yang mensuplai barang yang diperlukan.

Jurnallah Pembelian dilakukan via rekening pemasok tersebut.

Pada saat akad disepakati, terdapat beberapa transaksi yang harus diakui oleh bank syariah. Transaksi tersebut adalah (1) konversi persediaan untuk ijarah menjadi aset ijarah, sebagai bentuk pengakuan atas adanya pengalihan hak guna kepada penyewa (2) Penerimaan biaya administrasi.

- Misalkan pada tanggal 10 Juni, PT. Namira menandatangani akad ijarah untuk sebuah mesin. Maka jurnal yang diperlukan pada waktu itu adalah: 


\section{BAGIAN 11 \\ AKUNTANSI MUDHARABAH}

\section{Tujuan Instruksional Umum}

1. Memahami konsep dasar aturan-aturan yang berlaku, standar akuntansi yang digunakan dalam Akuntansi Mudharabah

2. Memahami perlakuan Akuntansi Mudharabah

3. Menjelaskan pengertian dasar Akuntansi Mudharabah

4. Menjelaskan aturan-aturan dalam Akuntansi Mudharabah

5. Menjelaskan standar Akuntansi Mudharabah dalam PSAK No. 59 tentang Akuntansi Bank Syariah

6. Memahami perlakuan Akuntansi Mudharabah

\section{SUB POKOK BAHASAN}

\section{Pengertian dasar Akuntansi Mudharabah}

Investasi mudharabah adalah pembiayaan yang di salurkan oleh bank syariah kepada pihak lain untuk suatu usaha yang produkif.

Sedangkan menurut Antonio (2001) secara teknis mudharabah adalah Akad kerjasama usaha antara pemilik dana (shohibul maal) dan pengelola dana (mudharib) 
dengan nisbah bagi hasil menurut kesepakatan dalam kontrak

\section{Aturan-aturan yang berlaku dalam Akuntansi}

\section{Mudharabah}

Ketentuan Syar'i MudharabahMenurut PSAK no.105 :

1. Mudharabah Muqayyadah

Shohibul maal memberikan batasan kepada mudharib mengenai tempat, cara dan objek investasinya

2. Mudharabah Muthlaqah

Shahibul maal memberikan kebebasan penuh kepada mudharib dalam pengelolaannya.

Dua jenis mudharabah muqayyadah dalam praktik perbankan, yakni :

a.Mudharabah muqayyadah executing

b.Mudharabah muqayyadah chanelling

3. Mudharabah musytarakah

Bentuk mudharabah dimana pengelola dana menyertakan modal dalam kerjasama investasi. Akad ini merupakan solusi sekiranya dalam perjalanan usaha, pengelola dana memiliki modal yang dapat dikontribusikan dalam investasi 


\section{Perlakuan Akuntansi Mudharabah}

Ketentuan akuntansi mudharabah diatur dalam pernyataan standar akuntansi (PSAK) no 105 th 2007 tentang akuntansi mudharabah. Standar ini mengatur pengakuan dan pengukuran transaksi baik dari sisi pemilik dana maupun dari sisi pengelola dana.

\section{EVALUASI}

○ Tanggal 1 Agustus 20XA Bank Murni Syariah (BMS) menyetujui pemberian fasilitas mudharabah Muthlaqah PT Haniya yang bergerak di bidang SPBU dengan kesepakatan sebagai berikut :

○ Plafond : Rp 1.450.000.000

○ Objek bagihasil : Pendapatan (Gross profit sharing)

○ Nisbah : $70 \%$ PT. Haniya dan $30 \%$ BMS

○ Jangka Waktu : 10 bulan (jatuh tempo tanggal 10 Juni 20XB)

○ Biaya administrasi $\quad: 14.500 .000$ (dibayar saat akad ditandatangani) 
- Pelunasan

: Pengembalian pokok di akhir periode

○ Keterangan : modal dari BMS diberikan secara tunai tanggal 10 Agustus 20XA. Pelaporan dan pembayaran bagi hasil oleh nasabah dilakukan setiap tanggal 10 mulai bulan September 


\section{BAGIAN 12 \\ AKUNTANSI MUSYARAKAH}

\section{Tujuan Instruksional Umum}

1. Memahami konsep dasar aturan-aturan yang berlaku, standar akuntansi yang digunakan dalam Akuntansi Musyarakah

2. Memahami perlakuan Akuntansi Musyarakah

3. Menjelaskan pengertian dasar Akuntansi Musyarakah

4. Menjelaskan aturan-aturan dalam Akuntansi Musyarakah

5. Menjelaskan standar Akuntansi Musyarakah dalam PSAK No. 59 tentang Akuntansi Bank Syariah

6. Memahami perlakuan Akuntansi Musyarakah

\section{SUB POKOK BAHASAN}

\section{Pengertian dasar Akuntansi Musyarakah}

IAI dalam PSAK no 106 mendefinisikan musyarakah sebagai akad kerja sama antara dua pihak atau lebih untuk suatu usaha tertentu dengan kondisi masingmasing pihak memberikan kontribusi dana, dengan 
ketentuan bahwa keuntungan dibagi berdasarkan kesepakatan sedangkan kerugian berdasarkan kontribusi dana.

\section{Aturan-aturan yang berlaku dalam Akuntansi}

\section{Musyarakah}

Transaksi Musyarakah ada 2:

- Musyarakah hak milik(syirkatul amlak) adalah persekutuan dua orang atau lebih dalam kepemilikan salah satu barang dengan salah satu sebab kepemilikan seperti jual beli,hibah atau warisan.

- Musyarakah akad (syirkatul uqud) adalah akad kerjasama dua orang atau lebih yang bersekutu dalam modal atau keuntungan.

Berdasarkan perbedaan peran dan tanggungjawab para mitra yang terlibat, musyarakah akad dapat diklasifikasikan atas musyarakah 'inan, musyarakah abdan, musyarakah wujuh dan musyarakah muwafadhah.

a. Musyarakah 'inan adalah kerjasama antara dua orang atau lebih dengan

modal yang mereka miliki bersama untuk membuka usaha yang mereka lakukan sendiri, lalu berbagi keuntungan bersama. Kewenangan mitra dalam musyarakah inan bersifat terbatas pada persetujuan 
mitra yang lain.Praktik musyarakah dalam dunia perbankan umumnya didasarkan atas konsep musyarakah 'inan.

b. Musyarakah abdan (syirkah usaha) yaitu kerjasama antara dua pihak atau

lebih dalam usaha yang dilakukan oleh tubuh (praktik) mereka, seperti kerjasama sesama dokter di klinik atau sesama tukang jahit, sesama akuntan/konsultan

c. Musyarakah wujuh adalah kerjasama dua pihak atau lebih, dengan cara

mereka membeli barang dengan menggunakan nama baik mereka dan kepercayaan pedagang kepada mereka tanpa keduanya memiliki modal uang sama sekali, menjualnya dengan pembagian keuntungan mereka dan pedagang, lalu setelah dijual bagian keuntungan mereka dibagi bersama.

d. Musyarakah mufawadhah adalah musyarakah dimana para anggotanya

memiliki kesamaan dalam modal, aktivitas dan hutang piutang, dari mulai berdirinya musyarakah hingga akhir (jika asas persamaan tidak terpenuhi kategorinya masuk pada musyarakah inan). 


\section{Standar Akuntansi Musyarakah}

Musyarakah adalah akad kerja sama antara dua pihak atau lebih untuk suatu usaha tertentu, di mana masingmasing pihak memberikan kontribusi dana dengan ketentuan bahwa keuntungan dibagi berdasarkan kesepakatan sedangkan kerugian berdasarkan porsi kontribusi dana. Dana tersebut meliputi kas atau aset nonkas yang diperkenankan oleh syariah.

IAI dalam PSAK no 106 mendefinisikan musyarakah sebagai akad kerja sama antara dua pihak atau lebih untuk suatu usaha tertentu dengan kondisi masingmasing pihak memberikan kontribusi dana, dengan ketentuan bahwa keuntungan dibagi berdasarkan kesepakatan sedangkan kerugian berdasarkan kontribusi dana.

\section{Perlakuan Akuntansi Musyarakah}

Pengakuan dan pengukuran dari pembiayaan musyarakah adalah sebagai berikut:

1. Pembiayaan musyarakah dalam bentuk kas dimulai sebesar jumlah yang dibayarkan 
2. Pembiayaan musyarakah yang diberikan da;lam bentuk aktiva non kas dinilai sebesar nilai wajar aktiva non kas, selisih antara nilai wajar dan nilai buku aktiva non kas di akui sebagai keuntungan atau kerugian bank pada saat penyerahan.

3. Biaya-biaya yang timbul aibat akad musyarakah tidak dapat diakui sebagai bagian pembiayaan musyarakah kecuali ada persetujuan dari seluruh mitra musyarakah

4. Pengakuan keuntungan/pendapatan dan kerugian musyarakah

Dalam pembiayaan musyarakah yang di mulai dan berakhir pada periode pelaporan yang sama, keuntungan atau pendapatan diakui pada saat terjadinya pembayaran apabila dalam pembiayaan musyarakah menggunakan metode bagi laba (profit sharing) di mana masa sebelumya terjadi keuntungan, maka keuntungan yang di peroleh pada masa tersebut harus di alokasikan terlebih dahulu untuk memulihkan pengurangan modal akibat kerugian pada masa sebelunyanya. 
Apabila pembiayaan musyarakah melewati satu periode pelaporan.

1. Keuntungan atau pendapatan pembiayaan musyarakah di akui pada saat terjadinya pembayaran

2. Kerugian yang terjadi di akui pada periode terjadinya kerugian tersebut dan mengurangi pembiayaan musyarakah apabila dalam pembiayaan musyarakah menggunakan metode bagi laba, dimana metode sebelumnya terjadi kerugian, maka keuntungan yang di peroleh pada periode tersebut harus di alokasiakan terlebih dahulu untuk memulihkan pengurangan modal akibat kerugian pada periode sebelumnya.

3. Pada saat akad berakhir, keuntungan yang belum diterima bank dari mitra musyarakah yang diakui sebagai piutang musyarakah.

4. Apabila terjadi kerugian dalam musyarakah akibat kelalaian atau penyimpangan mitra musyarakah, mitra yang melakukan kelalaian tersebut menanggung beban kerugian itu. Kerugian bank yang di akibatkan kelalaian atau penyimpangan mitra tersebut di akui sebagai piutang musyarakah. 
5. Pada saat akad di akhiri, saldo pembayaran musyarakah yang belum di terima sebagai sebagai piutang musyarakah.

6. Pembiayaan musyarakah permanen dimulai sebesar nilai perolehan setelah dikurangi dengan kerugian yang telah di akui.

7. Pembiayaan musyarakah menurun di sajikan sebesar harga perolehannya di kurangi bagian yang telah dialihkan kepada mitra musyarakah.

\section{EVALUASI}

- Pada tanggal 2 Februari 20XA Bu Nasibah menandatangani akad pembiayaan usaha penggilingan padi (membeli padi, menggiling selanjutnya menjual beras) dengan Bank Murni Syariah (BMS) dengan skema musyarakah sebagai berikut:

- Nilai Proyek : Rp 80.000.000

- Kontribusi Bank : Rp 60.000 .000 (pembayaran tahap pertama sebesar Rp 35.000 .000 dilakukan tanggal 12 Februari, pembayaran tahap kedua sebesar Rp 25.000.000,- dilakukan tanggal 2 Maret)

- Kontribusi Bu Nasibah : Rp 20.000.000 
- Nisbah bagi hasil

: Bu Nasibah 75\% dan BMS $25 \%$

- Periode

: 6 Bulan

- Biaya administras

: $\mathrm{Rp} \quad 600.000 \quad(1 \%$ dari pembiayaan bank)

- Objek bagi hasil : Laba Bruto (selisih harga jual beras dikurangi harga pembelian padi)

- Skema pelaporan dan pembayaran porsi bank : Setiap tiga bulan (dua kali masa panen) pada tanggal 2 Mei dan 2 Agustus 20XA

- Skema pelunasan Pokok : Musyarakah permanen

- dilunasi pada saat akad berakhir tanggal 2 Agustus 20XA 


\section{REFERENSI}

Al-Quran dan Terjemahannya.

Bank Indonesia, Pedoman Akuntansi Perbankan Syariah indonesia, Bank Indonesia : PAPSI 2003

Husein Syahatah, Pokok-Pokok Pikiran Akuntansi Islam, Penerbit Akbar, Jakarta, 2001.

Iwan Triyuwono, Organisasi dan Akuntansi Syariah, LkiS, 2000

IAI, PSAK, 2012

IAI, Modul Pelatihan Akuntansi Syariah, 2013

Sofyan S.Harahap, Wiroso, Akuntansi Perbankan Syariah,

LPFE Usakti, Jakarta 2004.

Sofyan Syafri Harahap ,Bunga Rampai Akuntansi Islam, Pustaka Kuantum, Jakarta, 2003.

Sofyan Syafri Harahap, Krisis Akuntansi Kapitalis, Pustaka Kuantum, Jakarta, 2007.

Sunarto Zulkifli; Panduan Praktis Transaksi Perbankan Syariah, Penerbit Zikrul Hakim, 2003.

Sumar'in, Konsep Kelembagaan Bank Syariah.Graha Ilmu. 2012

Sri Nurhayati; Wasilah, Akuntansi Syariah di Indonesia, Edisi

2, Penerbit Salemba Empat, 2009. 
Yaya R., Martawiredja A.E., Abdurahim A AKUNTANSI PERBANKAN SYARIAH: Teori dan Praktik Kontemporer (2009). Salemba Empat 